\title{
Topical Phenytoin Effects on Palatal Wound Healing
}

\section{Thesis}

Presented in Partial Fulfillment of the Requirements for the Degree Master of Science in the Graduate School of The Ohio State University

\author{
By \\ Anuja Anjan Doshi, B.D.S \\ Graduate Program in Dentistry
}

The Ohio State University

2019

Masters Committee:

Dr. Dimitris N. Tatakis, Advisor

Dr. Binnaz Lebleblicioglu

Dr. James McAuley 


\section{Copyrighted by}

Anuja Doshi

2019 


\begin{abstract}
Objectives: The proven clinical benefits of palatal soft tissue grafts are countered by associated donor site morbidity and occasional healing delays, indicating a need to improve donor site outcomes. Studies have shown improved healing with phenytoin (PHT) application on chronic and acute wounds in various tissues. The aim of this prospective split-mouth clinical trial is to assess clinical, histological and patient-centered outcomes following topical PHT treatment of experimental palatal wounds.

Material and Methods: 20 systemically healthy adult non-smokers were recruited. One $6 \mathrm{~mm}$ diameter wound (posterior) and one $4 \mathrm{~mm}$ diameter wound (anterior), each 1-1.5 $\mathrm{mm}$ deep, were created on both sides of the palate using custom stents and biopsy punches. Wounds on one randomly chosen side received PHT $(10 \%$ Phenytoin USP in $30 \%$ poloxamer gel; test) and on the other received carrier alone (30\% poloxamer gel; control). Participants were blinded to treatment allocation. Customized stents were worn after medication application for wound protection. Treatments were reapplied on postoperative Days 1 (D1) and 5 (D5). Biopsies were harvested from the anterior wounds, either on D1 (Group 1) or on D5 (Group 2), and were routinely processed for histology (H\&E, Masson trichrome). Posterior wounds were left undisturbed to clinically evaluate healing (using photographs and Healing Score Index) on D1, D5, D14 and D21. Questionnaires and Oral Health Impact Profile14 (OHIP14) was used to assess patient centered outcomes. Histomorphometry was performed on both H\&E and Masson stained


sections. Descriptive statistics were calculated. Data analysis was performed using Generalized Logistic Model and Generalized Linear Mixed Model.

Results: All 20 participants completed all visits. No adverse events were observed on PHT side; one control side exhibited liver clot formation (D1). Clinically, PHT treated sites were more likely to not exhibit swelling $(\mathrm{OR}=9.35 ; \mathrm{p}=0.009)$ and to not experience pain on palpation $(\mathrm{OR}=6.278 ; \mathrm{p}=0.007)$. $\mathrm{PHT}$ also had a significant and time-dependent effect on granulation tissue appearance $(\mathrm{p}=0.004)$. Overall, the Healing Score Index was significantly higher (suggestive of better healing) on PHT side at Day $5(\mathrm{p}=0.037)$ and Day $21(\mathrm{p}=0.003)$ than control side. As for patient reported outcomes, at Day 1, 30\% reported more pain on control side whereas none of the participants reported more pain on PHT side. This difference in relative pain was statistically significant $(\mathrm{p}=0.014)$. Although the mean VAS (pain) scores were consistently lower on PHT sites than the control sites, the difference was not statistically significant $(\mathrm{p}=0.533)$. There was no statistically significant difference in OHIP-14 scores between the two biopsy time groups. However, the total analgesic consumption was significantly higher in Group 1 than in Group $2(\mathrm{p}=0.00001)$.

Conclusions: Topical PHT application on experimental palatal wounds that model free gingival graft donor sites results in improved objective clinical outcomes. This study provides new information on post-harvesting palatal wound morbidity and healing, and is the first one to report on the possible effects of topical PHT as a palatal wound treatment regimen. 


\section{Dedication}

This thesis is dedicated to my sister, Parita. Thank you for always being there for me and cheering me on . Your compassion, patience and determination continue to amaze and inspire me every single day.

In memory of my beloved grandparents.

I hope I have made you proud. 


\section{Acknowledgments}

First and foremost, I would like to thank my research mentor, Dr. Dimitris Tatakis, for his invaluable support, encouragement and guidance throughout residency and beyond. Thank you for seeing my potential when I didn't see it for myself and for being such an inspiration. If we had a conventional classroom, I would get on a desk and proclaim “Oh, Captain! My captain!” (a la Dead Poets Society).

I would like to thank to my committee members, Dr. Binnaz Lebleblicioglu and Dr. James McAuley, for their advice and feedback that helped make my thesis what it is today. I would also like to thank Ms. Laura McCallister for all her help and assistance with my research project.

Finally, I must express my profound gratitude to my parents for providing me with unfailing support and continuous encouragement throughout my years of study. This accomplishment would not have been possible without them.

An enormous thanks to my boyfriend, Kirti Deo Mishra, for being my rock and loving me so unconditionally. To my best friend, Siddhant Dwivedee, because I don't know what would have I done without him. To my brother, Karan Doshi, for always being someone I could count on.

Lastly, a big shout-out to all my wonderful co-residents and in particular, Class of 2019 - Drs. Brett, Kasabreh, Nesmith and Sakulpaptong, for being absolutely the best! 
Vita

February 20, 1991.................................... Born - Mumbai, India 2014......................................, Maharashtra University of Health Sciences 2016 - present...........Post-doctoral Training in Periodontics, The Ohio State University

Fields of Study

Major Field: Dentistry 


\section{Table of Contents}

Abstract




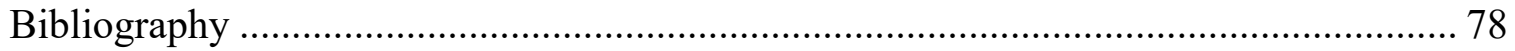




\section{List of Tables}

Table 1. Clinical Effects of Topical Phenytoin on Wound Healing in Humans................ 5

Table 2. Effects of Topical Phenytoin on Experimental Wounds in Animals ................. 12 


\section{List of Figures}

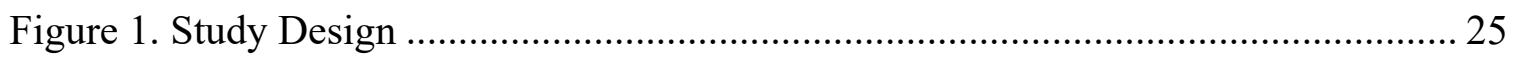

Figure 2. Surgical stent (A), Biopsy Punch with depth indicator (B), Post-operative stent

(C), Wounding procedure (D) Phenytoin and Poloxamer gel delivery syringes (E) ....... 26

Figure 3. A) Occlusal view of bilateral $6 \mathrm{~mm}$ diameter posterior wounds and $4 \mathrm{~mm}$ diameter anterior wounds. B) Palatal view of both wounds. C) Phenytoin application. .. 27 Figure 4.A) Circumferential punch incision (6 mm diameter) around the anterior wound (Day 1). B) Gross specimen of punch biopsy harvest. C) Biopsy harvest sectioned in two

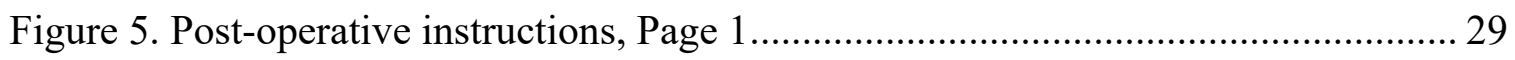

Figure 6. Post-operative instructions, Page 2 ....................................................... 30

Figure 7. Post-Operative Day 1 Questionnaire, Page 1 ................................................ 31

Figure 8. Post-Operative Day 1 Questionnaire, Page 2 ........................................... 32

Figure 9. Post-Operative Day 1 Questionnaire, Page 3 ............................................ 33

Figure 10. Post-Operative Day 5 Questionnaire, Page 1 ............................................. 34

Figure 11. Post-Operative Day 5 Questionnaire, Page 2 ........................................ 35

Figure 12. Post-Operative Day 5 Questionnaire, Page 3 ......................................... 36

Figure 13. Post-Operative Day 14 Questionnaire, Page 1 .......................................... 37

Figure 14. Post-Operative Day 14 Questionnaire, Page 2 ....................................... 38

Figure 15. Post-Operative Day 14 Questionnaire, Page 3 .......................................... 39 
Figure 16. Post-Operative Day 21 Questionnaire, Page 1 ........................................... 40

Figure 17. Post-Operative Day 21 Questionnaire, Page 2 .......................................... 41

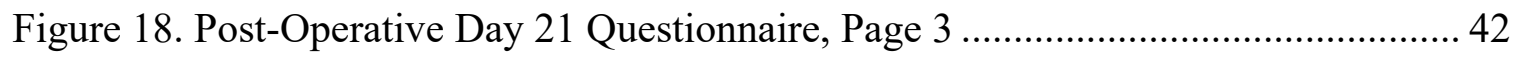

Figure 19. Post-Operative Day 21 Questionnaire, Page 4 .......................................... 43

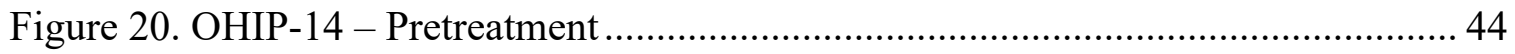

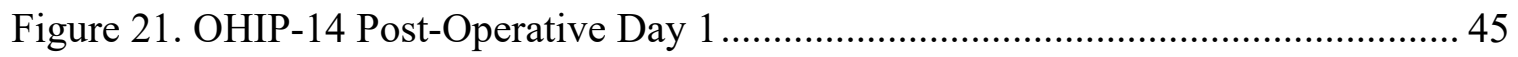

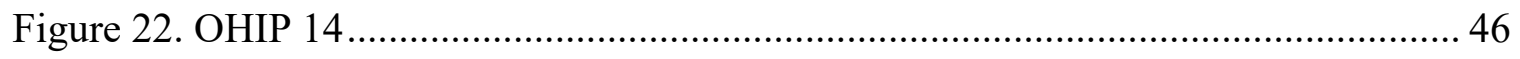

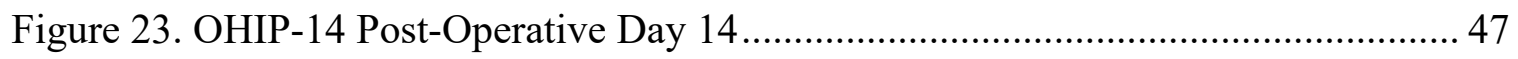

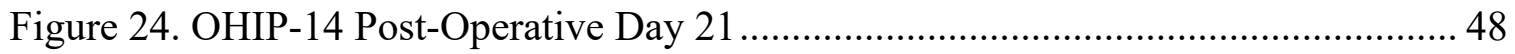

Figure 25. Imaging software analysis. Sterile paper scale next to a Day 14 posterior wound for calibration (A), Same wound zoomed-in (B), Immature wound areas selected

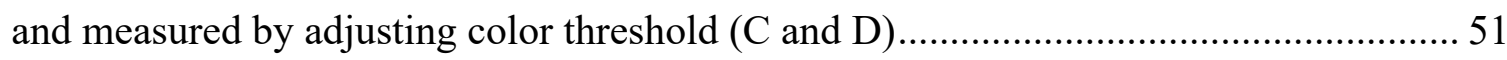
Figure 26. Histomorphological measurements. Superficial contraction (S) measured as indicated by solid arrow and original wound length (L) measured as indicated by dashed

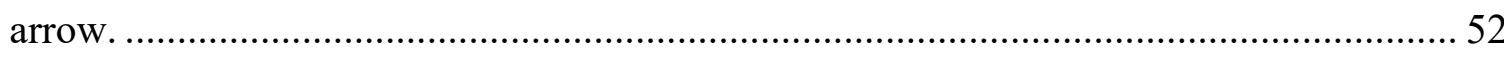

Figure 27. Clinical wound healing sequence from representative study participant

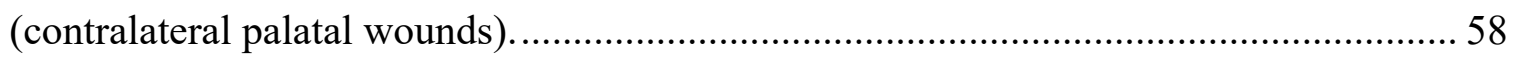

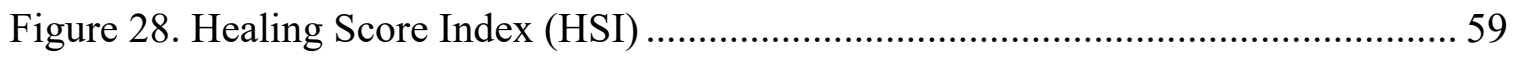

Figure 29. Healing Score Index - Individual components at Day 1 ............................. 59

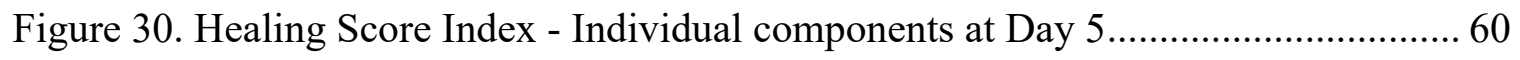

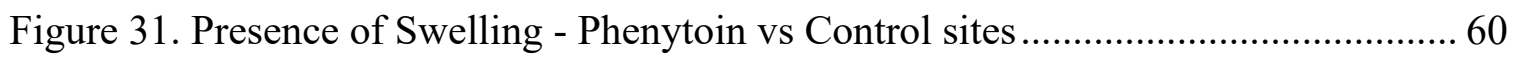

Figure 32. Presence of Pain on Palpation - Phenytoin vs Control sites .......................... 61

Figure 33. Presence of Granulation Tissue - Phenytoin vs Control sites....................... 61 
Figure 34. Changes in wound area measured as percentage of original standardized

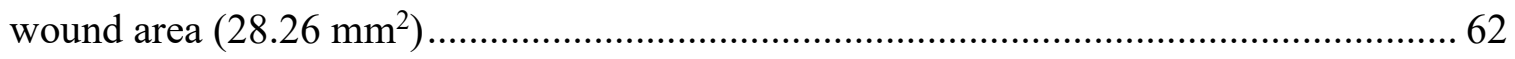

Figure 35. Patient reported relative pain at each follow-up visit................................. 63

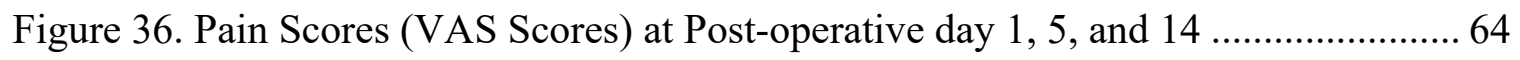

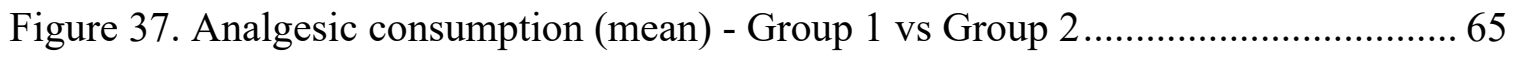

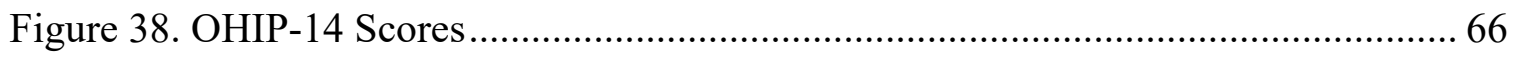

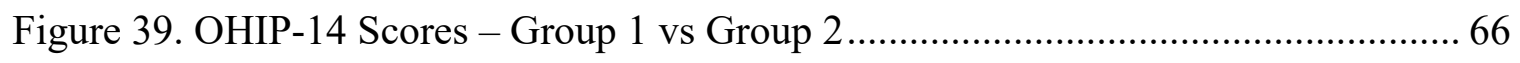

Figure 40. A-C Hematoxylin \& Eosin Stain (4x), D-E Masson Trichrome Stain (4x) .... 67

Figure 41. A-C Hematoxylin and Eosin Stain (10x), D-E Masson Trichrome Stain

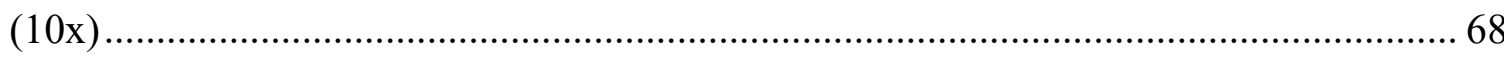

Figure 42. Histological outcomes. Superficial Contraction Index - Phenytoin vs Control

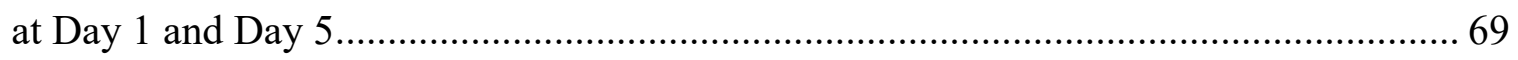




\section{Chapter 1. Introduction}

\section{Gingival Recession and Treatment}

Gingival grafts harvested from the palate and used for gingival tissue augmentation, around teeth or implants, or to treat gingival recession, i.e., exposed root surfaces, or to augment soft tissue volume, in intraoral (edentulous ridges) and extraoral sites, are one of the most well established and most commonly performed periodontal clinical procedures. Esthetics, dental hypersensitivity, and the prevention of caries and non-carious cervical lesions (NCCLs) are considered the main indications reported in the literature.

Over the years, many soft tissue root coverage procedures have been proposed and used for the treatment of gingival recession $(\mathrm{GR})^{1}$. Although predictable and effective, these procedures can be accompanied, as any other surgical procedure, by complications. Evidence indicates that graft harvesting from the palatal masticatory mucosa can be accompanied by postoperative pain and discomfort, the magnitude of which is related to the surgical approach used, the size of the wound/harvested graft, and the time it takes for the wound to heal/epithelialize. Such healing complications are more common and/or more severe in patients who are systemically compromised, commonly diabetics and smokers.

Of the autogenous soft tissue graft procedures, free gingival graft (FGG) and 
subepithelial connective tissue graft (SCTG) are the two most commonly used procedures. According to a recent systematic review ${ }^{1}, \mathrm{SCTG}_{\text {provides the best and the }}$ most predictable root coverage outcomes for Miller Class I and II recession-type defects and significantly increases width of keratinized tissue. The clinical advantages of a SCTG procedure are also apparent at the donor site, as most surgical techniques used for the graft harvest are conservative. However, a conservative SCTG harvest is a technique sensitive procedure that not only requires clinical expertise but also the presence of thick palatal tissues to obtain an adequately thick graft without compromising the residual epithelial-connective tissue layer at the donor site. On the other hand, FGG harvest is relatively a less technique sensitive procedure that allows the clinician to harvest sufficient amount of high-quality connective tissue irrespective of palatal tissue thickness $^{2}$. Conversely, it produces an open wound at the donor site that heals by secondary-intention which results in greater incidence of donor site pain and discomfort compared to SCTG, particularly during the early postoperative period ${ }^{3}$. Therefore, there is a great and real need to improve the wound healing outcomes of palatal graft harvesting.

To reduce the postoperative pain and discomfort associated with the FGG donor site, several clinical studies have tested novel post-operative protocols such as hemostatic agents $^{4}$, collagen matrix ${ }^{5}$, ozonated oil ${ }^{6}$, medicinal plant extracts, anti-bacterial agents, platelet concentrates ${ }^{7,8}$ and most recently simvastatin ${ }^{9}$.

\section{$\underline{\text { Phenytoin }}$}

Phenytoin (PHT; diphenylhydantoin, DILANTIN), first synthesized in 1908, was 
not formally recognized as an anticonvulsant drug until $1938^{10}$. Kimball and Horan, in 1939, were the first to describe PHT's adverse effects on gingiva ${ }^{11}$. Since then, a considerable amount of literature has been published on PHT-induced gingival enlargement. Studies on PHT-induced gingival enlargement suggest that in patients treated with systemic PHT the responding gingival tissue fibroblasts exhibit increased protein synthetic activity (twice that of normal tissues) and double the relative amount of collagen production ${ }^{12}$. Immunohistochemistry studies indicate that transforming growth factor beta (TGFb), basic fibroblast growth factor (bFGF), and heparan sulphate proteoglycan (HSPG) are highly expressed in PHT-enlarged gingiva, ${ }^{13}$ as is connective tissue growth factor (CTGF/CCN2). ${ }^{14}$ Gene expression studies have reported highly elevated CTGF/CCN2 mRNA expression (>6-fold over controls) in PHT-enlarged gingiva, with increased expression in both the connective tissue and epithelial components of the gingiva. ${ }^{14}$ The aforementioned studies on the possible implicated molecular mechanisms of PHT action have relied on the study of tissues already undergone clinical enlargement, a process that typically takes months to manifest itself; therefore, there is no information available on the immediate in-vivo effects of PHT on gingival gene expression.

\section{Effects of Topical Phenytoin on Wound Healing: Review of Literature}

The apparent stimulatory effect of the drug on connective tissue metabolism suggested a possibility for its use in wound healing. In 1958, Shapiro ${ }^{15}$ was the first to conduct a controlled clinical trial and demonstrate, both clinically and histologically, the accelerated healing of periodontal surgical wounds in non-epileptic patients pre- 
medicated with systemic (orally administered) PHT.

Several human studies ${ }^{18-37}$ (Table 1) and animal studies ${ }^{20,38-43}$ (Table 2) have since investigated the effects of different topical PHT formulations on the healing of a variety of chronic and acute wounds such as diabetic foot ulcers, burn wounds, war wounds, excisional biopsies, pressure sores, chronic venous ulcers, and experimental wounds. These studies suggested that PHT promotes wound healing by increasing the vascularity of granulation tissue and by stimulating fibroblast proliferation and maturation of collagen content. No evidence of systemic PHT absorption or PHT toxicity has been reported after topical application of the drug ${ }^{16,17}$. Hence, PHT's evident healing properties, long-established safety profile and low-cost support its potential use as a wound healing agent.

To the best of our knowledge, to date, no clinical trials have evaluated the possible benefits of topical PHT application on the healing of gingival wounds, in general, or of palatal soft tissue donor sites, in particular. 
Table 1. Clinical Effects of Topical Phenytoin on Wound Healing in Humans.

\begin{tabular}{|c|c|c|c|}
\hline Name & Wound Details & Phenytoin (Dose/ Formulations) & Results \\
\hline $\begin{array}{c}\text { El Zayat et al } \\
1989 \mathbf{1 8}\end{array}$ & $\begin{array}{l}\text { War related wounds: } \\
\text { Decubitus ulcers of } \\
\text { varying severity that } \\
\text { had resulted from war- } \\
\text { related injuries, as well } \\
\text { as intractable missile } \\
\text { wounds. Average } \\
\text { wound size: } 4 \mathrm{~cm} \text { wide, } \\
15 \mathrm{~cm} \text { deep. }\end{array}$ & $\begin{array}{l}\text { Ulcers were debrided as necessary, } \\
\text { cleansed with saline, dried, and } \\
\text { covered by a thin uniform layer of } \\
\text { PHT powder and sterile gauze } \\
\text { daily. }\end{array}$ & $\begin{array}{l}\text { Significantly accelerated } \\
\text { healing, provided local pain } \\
\text { relief, reduced wound } \\
\text { transudate or exudate, } \\
\text { reduced or eliminated } \\
\text { bacterial wound } \\
\text { contamination, decreasing } \\
\text { the need for antibiotic } \\
\text { therapy. }\end{array}$ \\
\hline $\begin{array}{c}\text { Modaghegh et al } \\
1989^{19}\end{array}$ & $\begin{array}{l}\text { War and Non-War } \\
\text { wounds }\end{array}$ & $\begin{array}{l}\text { Wound was cleansed with normal } \\
\text { saline, dried, and covered with a } \\
\text { uniform, thin layer of phenytoin } \\
\text { sodium powder. The dressings } \\
\text { were changed daily. }\end{array}$ & $\begin{array}{l}\text { Local pain relief, reduced } \\
\text { the need for pain } \\
\text { medications; decreased } \\
\text { wound exudation and } \\
\text { elimination of bacterial } \\
\text { contamination; Provided a } \\
\text { healthy granulation tissue } \\
\text { base for skin grafting and } \\
\text { surgical wound closure. }\end{array}$ \\
\hline $\begin{array}{c}\text { Lodha et al } \\
1991^{20}\end{array}$ & $\begin{array}{l}\text { Large abscess cavities } \\
\text { secondary to } \\
\text { intramuscular } \\
\text { injections in the gluteal }\end{array}$ & $\begin{array}{l}\text { Phenytoin-sodium power was } \\
\text { delivered topically in a fixed dose } \\
\text { of } 20 \mathrm{mg} / \mathrm{cm}^{2} \text { by making a series of } \\
25 \text { perforations in a } 5 \times 5 \text { grid over }\end{array}$ & $\begin{array}{l}\text { The topical application of } \\
\text { phenytoin significantly } \\
\text { enhanced healing when } \\
\text { compared with }\end{array}$ \\
\hline
\end{tabular}


Table 1. Continued

\begin{tabular}{|c|c|c|c|}
\hline & $\begin{array}{l}\text { region. Mean wound } \\
\text { areas was } 37.5 \mathrm{~cm}^{2}\end{array}$ & $\begin{array}{l}\text { a } 1 \mathrm{~cm}^{2} \text { area on the bottle cap. Each } \\
\text { tap of the bottle yielded } 4 \mathrm{mg} \text { of } \\
\text { phenytoin-sodium. }\end{array}$ & conventional treatment. \\
\hline $\begin{array}{c}\text { Muthukumaraswamy } \\
1991^{21}\end{array}$ & $\begin{array}{l}\text { Diabetic foot ulcers of } \\
\text { type } 1 \text { and } 2 \text { of } \\
\text { Meggitt's clinical } \\
\text { classification were } \\
\text { included in the study. }\end{array}$ & $\begin{array}{l}\text { Phenytoin powder was applied in a } \\
\text { thin uniform layer to the ulcer } \\
\text { surface and a sterile dry dressing } \\
\text { applied, repeated daily. }\end{array}$ & $\begin{array}{l}\text { Complete wound healing } \\
\text { occurred in an average } 21 \\
\text { days with phenytoin and } 45 \\
\text { days with control. Quality } \\
\text { of the scar formation was } \\
\text { better in the PHT group }\end{array}$ \\
\hline $\begin{array}{c}\text { Menezes et al } \\
1993^{22}\end{array}$ & $\begin{array}{l}\text { Leprosy Trophic Ulcers } \\
\text { Location: Plantar ulcers } \\
\text { on the foot } \\
\text { Dimensions: } \sim 17 \mathrm{~mm} \\
\text { x } 8 \mathrm{~mm}\end{array}$ & $\begin{array}{l}\text { A thin film of Phenytoin powder } \\
\text { was dusted on the ulcers followed } \\
\text { by a plain dressing }\end{array}$ & $\begin{array}{l}\text { Added accelerated healing } \\
\text { in the phenytoin group. }\end{array}$ \\
\hline $\begin{array}{l}\text { Yadav et al } \\
1993^{\mathbf{2 3}}\end{array}$ & $\begin{array}{l}\text { Split-thickness skin } \\
\text { autograft donor sites. } \\
\text { Location: Thigh, leg. } \\
\text { Size: Partial- thickness } \\
\text { skin grafts ranging in } \\
\text { size from } 1-5 \mathrm{~cm} \times 1-5 \\
\mathrm{~cm} \text { to } 20 \mathrm{~cm} \times 20 \mathrm{~cm} \text {. }\end{array}$ & $\begin{array}{l}\text { The surface of the wound covered } \\
\text { with a thin, uniform layer of } \\
\text { phenytoin powder and petroleum } \\
\text { jelly- impregnated sterilized gauze. } \\
\text { Dressings changed daily. }\end{array}$ & $\begin{array}{l}\text { Complete healing (as } \\
\text { defined as full thickness } \\
\text { epithelial cover) occurred } \\
\text { randomly much earlier in } \\
\text { the PHT-treated group than } \\
\text { in the OpSite or Soframycin } \\
\text { group. }\end{array}$ \\
\hline
\end{tabular}

Continued 
Table 1. Continued

\begin{tabular}{|c|c|c|c|}
\hline $\begin{array}{c}\text { Pendse et al } \\
1993^{\mathbf{2 4}}\end{array}$ & $\begin{array}{l}\text { Chronic Skin Ulcers: } \\
\text { Burn, Postcellulitis, } \\
\text { Traumatic, Amputation } \\
\text { stump, Postoperative, } \\
\text { Nonspecific. } \\
\text { Ulcer size: } \sim 4.9 \mathrm{~cm}^{2} \text { to } \\
378 \mathrm{~cm}^{2}\end{array}$ & $\begin{array}{l}\text { Phenytoin powder was applied to } \\
\text { the surface in a thin uniform layer, } \\
\text { and the wound was covered with a } \\
\text { sterile, saline-soaked gauze and a } \\
\text { sterile dry dressing applied. }\end{array}$ & $\begin{array}{l}\text { Topical phenytoin } \\
\text { application significantly } \\
\text { accelerated wound healing } \\
\text { and improved the quality } \\
\text { and vascularity of } \\
\text { granulation tissue, with } \\
\text { greater wound area } \\
\text { reduction than controls. }\end{array}$ \\
\hline $\begin{array}{c}\text { Oluwatosin et al } \\
2000^{25}\end{array}$ & $\begin{array}{l}\text { Chronic leg ulcers: } \\
\text { Smallest ulcer was } 166 \\
\text { mm, the largest was } \\
26,226 \mathrm{~mm} \text { in size. All } \\
\text { the ulcers were either } \\
\text { posttraumatic or post } \\
\text { infective }\end{array}$ & $\begin{array}{l}\text { Phenytoin paste consisting of } 200 \\
\text { mg of the powder per ml. of normal } \\
\text { saline; } 1 \mathrm{ml} \text { of paste being applied } \\
\text { to an ulcer of size } \sim 10,000 \mathrm{~mm} \text {. } \\
\text { The mixture of phenytoin and } \\
\text { honey was obtained as } 200 \mathrm{mg} \text { of } \\
\text { phenytoin powder per ml. of honey }\end{array}$ & $\begin{array}{l}\text { Phenytoin was superior to } \\
\text { honey in treatment of } \\
\text { chronic ulcers, but the best } \\
\text { initial response was seen in } \\
\text { the honey group. }\end{array}$ \\
\hline $\begin{array}{c}\text { Carneiro et al } \\
2002 \mathbf{2 6}\end{array}$ & $\begin{array}{l}\text { Burn wounds - Small to } \\
\text { moderate size ( } 10 \text { to } \\
30 \% \text { ) superficial } \\
\text { dermal burn wounds } \\
\text { In half of the patients } \\
\text { the burns were on the } \\
\text { trunk }\end{array}$ & $\begin{array}{l}\text { Dry phenytoin powder and Silverex } \\
\text { powder was then sprinkled } \\
\text { topically on to the wounds in the } \\
\text { study and control group } \\
\text { respectively. }\end{array}$ & $\begin{array}{l}\text { Phenytoin analgesic } \\
\text { properties minimized the } \\
\text { need for pain medications. } \\
\text { There were more negative } \\
\text { bacterial wound cultures in } \\
\text { Phenytoin-than Silverex- } \\
\text { treated wounds }\end{array}$ \\
\hline
\end{tabular}

Continued 
Table 1. Continued

\begin{tabular}{|c|c|c|c|}
\hline $\begin{array}{c}\text { Carneiro et al } \\
2003^{27}\end{array}$ & $\begin{array}{l}\text { Non-Malignant } \\
\text { Chronic Leg Ulcers } \\
\text { Average Surface area: } \\
12-300 \mathrm{~cm}^{2}\end{array}$ & $\begin{array}{l}\text { A uniform thin layer of phenytoin } \\
\text { powder was sprinkled and in the } \\
\text { control group sterile gauze soaked } \\
\text { with Edinburgh University solution } \\
\text { of lime (EUSOL) was applied. In } \\
\text { both groups, ulcers were dressed } \\
\text { daily and followed up for } 28 \text { days }\end{array}$ & $\begin{array}{l}\text { Phenytoin more effectively } \\
\text { relieved pain, cleared } \\
\text { discharge and enhanced } \\
\text { formation of granulation } \\
\text { tissue thereby promoting } \\
\text { healing. }\end{array}$ \\
\hline $\begin{array}{c}\text { Bhatia et al } \\
2004 \mathbf{2 8}\end{array}$ & $\begin{array}{l}\text { Leprosy Trophic Ulcers } \\
\text { All ulcers were simple } \\
\text { i.e. involving only skin } \\
\text { and subcutaneous tissue } \\
\text { and having no bone } \\
\text { involvement. }\end{array}$ & $\begin{array}{l}2 \% \text { phenytoin- } \mathrm{NaCl} \\
\text { suspension: } 100 \mathrm{mg} \text { PHT sodium } \\
\text { powder }+5 \mathrm{ml} \text { of sterile } 0.9 \% \mathrm{NaCl} \\
\text { OR } 4 \% \text { phenytoin- } \mathrm{NaCl} \\
\text { suspension: } 200 \mathrm{mg} \mathrm{PHT} \text { sodium } \\
\text { powder }+5 \mathrm{ml} \text { of sterile } 0.9 \% \\
\mathrm{NaCl} \text {. } \\
\text { Sterile gauze was then soaked in } \\
\text { these suspensions and placed over } \\
\text { the wound, followed by a layer of } \\
\text { dry sterile gauze. }\end{array}$ & $\begin{array}{l}\text { Topical PHT resulted in the } \\
\text { quicker cessation of ulcer } \\
\text { discharge, quicker } \\
\text { appearance of healthy } \\
\text { granulation tissue and a } \\
\text { greater reduction in the } \\
\text { surface area of the ulcer } \\
\text { leading to faster healing. } \\
\text { No significant differences } \\
\text { between the two phenytoin } \\
\text { doses }\end{array}$ \\
\hline $\begin{array}{l}\text { Younes } \\
2006^{29}\end{array}$ & $\begin{array}{l}\text { Diabetic Foot Ulcers } \\
\text { Ulcer size }>20 \mathrm{~cm}^{2} \text {. } \\
\text { Dorsal foot ulceration, } \\
\text { post mid-tarsal } \\
\text { amputation ulcers, }\end{array}$ & $\begin{array}{l}\text { Phenytoin powder BP was } \\
\text { compounded with white petrolatum } \\
\text { BP (Vaseline) at a ratio of } 10 \\
\text { percent (w/w). A thin layer of } \\
\text { phenytoin ointment was applied } \\
\text { and ulcer was covered with a dry, }\end{array}$ & $\begin{array}{l}\text { Preparing the ulcer bed } \\
\text { with } 10 \text { percent phenytoin } \\
\text { was associated with a high } \\
\text { rate of skin graft acceptance }\end{array}$ \\
\hline
\end{tabular}

Continued 
Table 1. Continued

\begin{tabular}{|c|c|c|c|}
\hline & $\begin{array}{l}\text { plantar foot ulceration, } \\
\text { forefoot ulceration, and } \\
\text { left heel ulceration. }\end{array}$ & $\begin{array}{l}\text { sterile, non-occlusive gauze-pad } \\
\text { dressing. Repeated for } 2-8 \text { weeks. }\end{array}$ & \\
\hline $\begin{array}{l}\text { Subbanna } \\
2007^{\mathbf{3 0}}\end{array}$ & $\begin{array}{l}\text { Pressure ulcers: } \\
\text { Paraplegic patients } \\
\text { presenting with stage } 2 \\
\text { pressure ulcers without } \\
\text { necrotic tissue. Ulcer } \\
\text { volume: Average: } 3.70 \\
\text { ml }-4.85 \mathrm{ml}\end{array}$ & $\begin{array}{l}\text { Injection phenytoin solution ( } 50 \\
\mathrm{mg} / \mathrm{ml} \text { ) was diluted using normal } \\
\text { saline to prepare phenytoin solution } \\
(5 \mathrm{mg} / \mathrm{ml}) \text {. The preparation was } \\
\text { indistinguishable from the normal } \\
\text { saline in presentation, color, } \\
\text { density, and odor. } \\
\text { Sterile gauze soaked with PHT } \\
\text { solution were used as dressings } \\
\text { daily for } 15 \text { days. }\end{array}$ & $\begin{array}{l}\text { Phenytoin solution is a safe } \\
\text { topical agent that } \\
\text { accelerates pressure ulcer } \\
\text { healing process, although } \\
\text { its efficacy is only slightly } \\
\text { more than normal saline } \\
\text { treatment. }\end{array}$ \\
\hline $\begin{array}{l}\text { Hokkam } \\
2010^{\mathbf{3 1}}\end{array}$ & $\begin{array}{l}\text { Chronic venous ulcers } \\
\text { Ulcers were secondary } \\
\text { to varicose veins in } \\
43 \% \text { of the patients } \\
\text { while they were post- } \\
\text { thrombotic in } 55 \% \text {. } \\
\text { Mean ulcer size: } 5.7 \\
\mathrm{~cm}^{2} \text { to } 6.1 \mathrm{~cm}^{2}\end{array}$ & $\begin{array}{l}\text { Phenytoin is prepared in a lotion } \\
\text { form by adding } 1 \mathrm{~g} \text { of it to } 25 \mathrm{ml} \text { of } \\
\text { liposomal base and shook well } \\
\text { before application. }\end{array}$ & $\begin{array}{l}\text { The rate of reduction in the } \\
\text { mean surface area of the } \\
\text { ulcers was faster in the } \\
\text { study group than control } \\
\text { group (saline) }\end{array}$ \\
\hline $\begin{array}{c}\text { Fonseka } \\
2010^{32}\end{array}$ & $\begin{array}{l}\text { Pyoderma } \\
\text { Gangrenosum: } \\
\text { Behcet's or } \\
\text { Scleroderma/ Mixed }\end{array}$ & $\begin{array}{l}\text { Phenytoin sodium solution ( } 2 \%) \\
\text { was applied directly (in wet gauze) } \\
\text { to wounds daily. The solution was }\end{array}$ & $\begin{array}{l}\text { Topical phenytoin may be } \\
\text { highly effective when other } \\
\text { systemic or topical } \\
\text { treatments have been }\end{array}$ \\
\hline
\end{tabular}

Continued 
Table 1. Continued

\begin{tabular}{|c|c|c|c|}
\hline & $\begin{array}{l}\text { connective tissue } \\
\text { disorder or Idiopathic. } \\
\text { Size range: } 1-11 \mathrm{~cm} \mathrm{x} \\
1-4.5 \mathrm{~cm}\end{array}$ & made using normal saline. & unsuccessful. \\
\hline $\begin{array}{l}\text { Pereira } \\
2010^{33}\end{array}$ & $\begin{array}{l}\text { Skin wounds from } \\
\text { excision of melanocytic } \\
\text { nevi. } \\
\text { Lesions on the face and } \\
\text { on the back, totalizing } \\
\text { to } 200 \text { lesions excised } \\
\text { with } 6 \text { or } 8 \mathrm{~mm} \\
\text { modified punch. }\end{array}$ & $\begin{array}{l}\text { Cream was used as a vehicle for } \\
\text { the preparation of } 0.5 \% \text { topical } \\
\text { phenytoin, and the vehicle cream } \\
\text { was the control for the study, } \\
\text { constantly hydrating the wound to } \\
\text { avoid crusts or skin irritation }\end{array}$ & $\begin{array}{l}\text { Phenytoin showed a better } \\
\text { therapeutic and cosmetic } \\
\text { outcome. Phenytoin } 0.5 \% \\
\text { cream accelerated skin } \\
\text { wound healing with } \\
\text { excellent cutaneous } \\
\text { tolerability. }\end{array}$ \\
\hline $\begin{array}{c}\text { Baharvand } \\
2010^{34}\end{array}$ & $\begin{array}{l}\text { Chemotherapy induced } \\
\text { mucositis of grade } 2 \\
\text { (erythema, edema, or } \\
\text { painful lesions, but } \\
\text { solid diet tolerated) or } 3 \\
\text { (erythema, edema, and } \\
\text { oral ulcers with need } \\
\text { for intra- venous } \\
\text { hydration) according to } \\
\text { National Cancer } \\
\text { Institute (NCI) } \\
\text { classification. }\end{array}$ & $\begin{array}{l}\text { Phenytoin was prepared as an oral } \\
\text { rinse at a concentration of } 0.5 \% .10 \\
\text { ml for } 1 \text { minute (to distribute } \\
\text { evenly to all parts of the oral } \\
\text { tissues), and then expectorated (to } \\
\text { minimize the systemic absorption) }\end{array}$ & $\begin{array}{l}\text { Phenytoin mouthwash } \\
\text { accelerated healing of } \\
\text { mucositis and improved life } \\
\text { quality }\end{array}$ \\
\hline
\end{tabular}

Continued 
Table 1. Continued

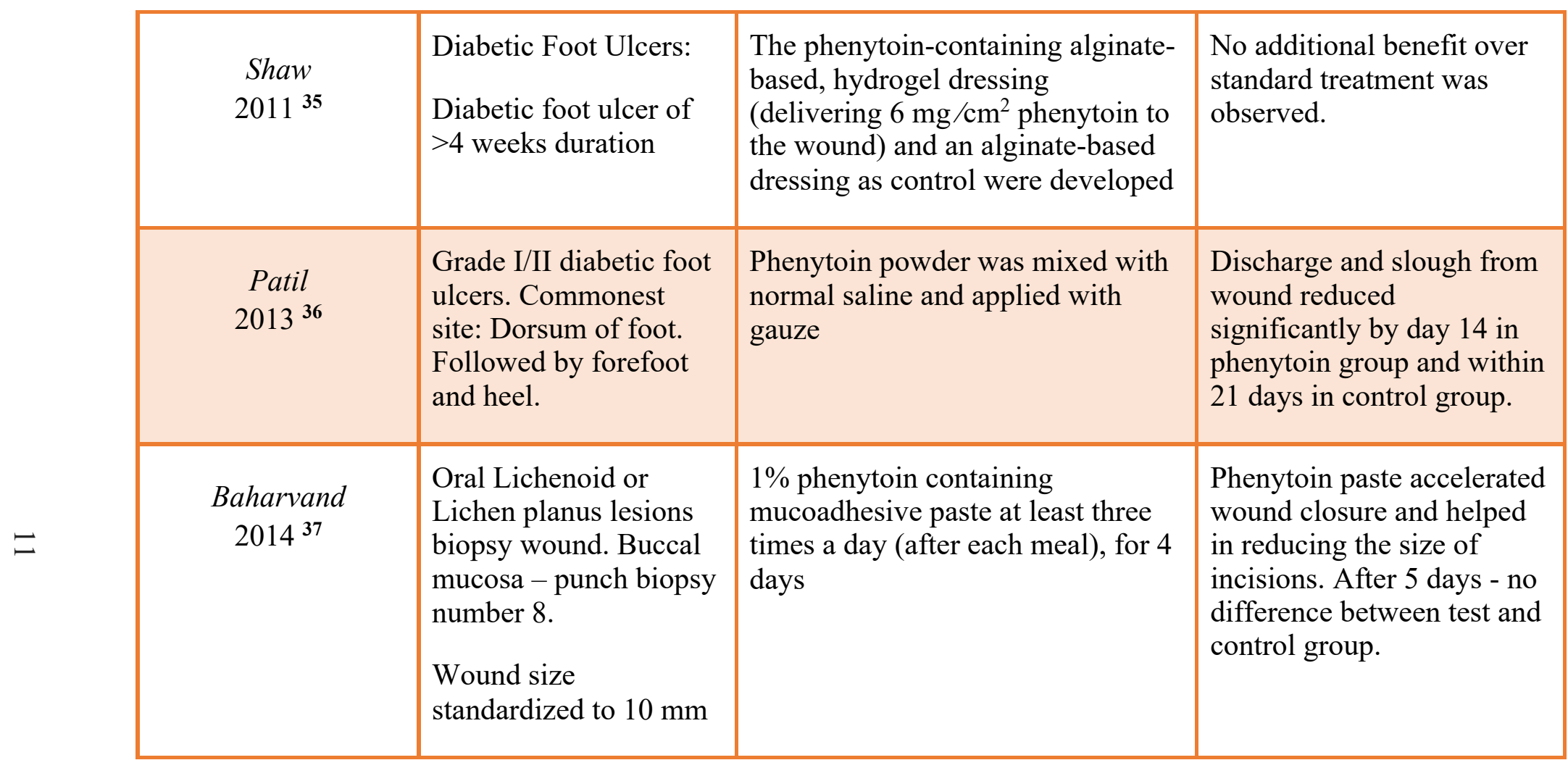


Table 2. Effects of Topical Phenytoin on Experimental Wounds in Animals

\begin{tabular}{|c|c|c|c|}
\hline Name & Wound Details & $\begin{array}{l}\text { Phenytoin (Dose/ } \\
\text { Formulations) }\end{array}$ & Results \\
\hline $\begin{array}{l}\text { Lodha } \\
1991^{20}\end{array}$ & $\begin{array}{l}3.5 \mathrm{~cm} \text { Infected } \\
\text { experimental wounds } \\
\text { on guinea pigs. }\end{array}$ & $\begin{array}{l}\text { Application of } 20 \mathrm{mg} / \mathrm{cm} 2 \text { with a } \\
\text { maximum total topical dose of } \\
300 \mathrm{mg} \text { of phenytoin-sodium per } \\
\text { daily dressing }\end{array}$ & $\begin{array}{l}\text { Increased epithelialization, reduction of } \\
\text { bacterial colonization and infection was } \\
\text { observed in the group treated with } \\
\text { phenytoin suggestive of its ability to } \\
\text { decrease inflammation, reduce edema } \\
\text { and enhance contraction of the wound. }\end{array}$ \\
\hline $\begin{array}{l}\text { Younes } \\
2006^{38}\end{array}$ & $\begin{array}{l}4 \mathrm{~cm} 2 \text { full thickness } \\
\text { skin was excised to } \\
\text { create wounds for } \\
\text { autograft acceptance } \\
\text { in rats. }\end{array}$ & $\begin{array}{l}\text { Phenytoin (PHT) powder was } \\
\text { triturated into white petrolatum } \\
\text { (Vaseline) at a ratio of } 10 \% \\
\text { (w/w) and was applied twice } \\
\text { daily to the wound area. }\end{array}$ & $\begin{array}{l}\text { PHT ointment increased the amount of } \\
\text { granulation tissue formation. The rate } \\
\text { of autograft acceptance was much } \\
\text { higher in the PHT treated group as } \\
\text { compared to the control group } \\
\text { (Vaseline alone). }\end{array}$ \\
\hline $\begin{array}{l}\text { Hasamnis } \\
2010^{39}\end{array}$ & $\begin{array}{l}\text { Round full thickness } \\
\text { excisional skin } \\
\text { wounds measuring } \\
500 \mathrm{~mm} 2 \text { were } \\
\text { created in the } \\
\text { paravertebral area of }\end{array}$ & $\begin{array}{l}\text { Preparation of } 1 \% \text { phenytoin } \\
\text { cream, } 1 \mathrm{~g} \text { of phenytoin powder } \\
\text { was added to } 99 \mathrm{~g} \text { of cold cream } \\
\text { and it was then applied twice } \\
\text { daily for } 16 \text { days. Control group } \\
\text { received no drug treatment. }\end{array}$ & $\begin{array}{l}\text { Topical phenytoin accelerated healing } \\
\text { of excisional wounds }\end{array}$ \\
\hline
\end{tabular}

Continued 
Table 2. Continued

\begin{tabular}{|c|c|c|c|}
\hline & albino rats. & & \\
\hline $\begin{array}{c}\text { Sayar } \\
2014^{40}\end{array}$ & $\begin{array}{l}\text { Experimental: } \\
\text { Second degree burn } \\
\text { wounds on rats }\end{array}$ & $\begin{array}{l}3 \% \text { PHT cream: } 3 \mathrm{~g} \text { of phenytoin } \\
\text { powder was incorporated with } \\
100 \mathrm{~g} \text { of simple ointment base. }\end{array}$ & $\begin{array}{l}\text { PHT contributes to healing by } \\
\text { increasing vascularized granulation } \\
\text { tissue and collagen synthesis through } \\
\text { re-epithelialization. PHT may be more } \\
\text { effective than Hypericin in the } \\
\text { treatment of deep wounds with tissue } \\
\text { defects. }\end{array}$ \\
\hline $\begin{array}{l}\text { Meena } \\
2011^{41}\end{array}$ & $\begin{array}{l}\text { Experimental burn } \\
\text { wounds on the } \\
\text { dorsum of rats }\end{array}$ & $\begin{array}{l}\text { Phenytoin base }(2.5 \mathrm{~g}) \text { was added } \\
\text { to liquid paraffin }(12.5 \mathrm{ml}) \text { in a } \\
\text { mortar while triturating. To this } \\
\text { mixture added molten hard } \\
\text { paraffin }(10 \mathrm{~g}) \text { and triturated } \\
\text { until a cream }(10 \%) \text { was formed. } \\
\text { Group I = control, Group II = } \\
\text { standard silver sulphadiazine, } \\
\text { Group III = topical phenytoin, } \\
\text { Group IV = injection } \\
\text { dexamethasone- } 0.17 \text { mg } / \mathrm{kg} \text {, } \\
\text { Group V = combination of } \\
\text { phenytoin and dexamethasone. }\end{array}$ & $\begin{array}{l}\text { The percentage of wound contraction } \\
\text { was significantly increased in the } \\
\text { topical phenytoin group compared to } \\
\text { silver sulphadiazine and control group, } \\
\text { and in phenytoin+dexamethasone } \\
\text { group in comparison to dexamethasone } \\
\text { alone group }\end{array}$ \\
\hline
\end{tabular}

Continued 
Table 2. Continued

\begin{tabular}{|c|c|c|c|}
\hline $\begin{array}{l}\text { Simsek } \\
2014^{42}\end{array}$ & $\begin{array}{l}\text { Experimental } \\
\text { wounds in the nasal } \\
\text { cavity of rats to } \\
\text { simulate wounds } \\
\text { after sinus surgeries. }\end{array}$ & $\begin{array}{l}1 \% \text { phenytoin cream ( } 1 \mathrm{~g} \text { of } \\
\text { phenytoin powder added to } 99 \mathrm{~g} \\
\text { of cold cream) was applied into } \\
\text { the right nasal cavity once daily } \\
\text { for } 1 \text { week. The control group } \\
\text { received no drug treatment. The } \\
\text { vehicle group received the } \\
\text { topical application of cold cream } \\
\text { daily for seven days. }\end{array}$ & $\begin{array}{l}\text { Intranasal phenytoin treatment } \\
\text { significantly altered wound healing via } \\
\text { increased epithelial proliferation and } \\
\text { angiogenesis. } \\
\text { (Tissue edema and inflammatory cell } \\
\text { infiltration were significantly } \\
\text { decreased, and PCNA and CD31 } \\
\text { immunoexpression levels were more } \\
\text { prominent and tissue EGF levels were } \\
\text { significantly higher.) }\end{array}$ \\
\hline $\begin{array}{c}\text { Xiao-yu } \\
\text { Ai } 2017^{43}\end{array}$ & $\begin{array}{l}\text { Sprague-Dawley } \\
\text { (SD) male rats: } 3 \\
\mathrm{~cm}^{2} \text { experimental } \\
\text { wounds. Minipig: } \\
\text { excisions of } 7 \mathrm{~cm}^{2}\end{array}$ & $\begin{array}{l}10 \mathrm{~mL} \text { of phenytoin sodium }(0.12 \\
\text { mol/L) was slowly added into the } \\
\text { silver ammonia solution under } \\
\text { ultrasonic condition. The } \\
\text { precipitate was washed with } \\
\text { deionized water and dried to } \\
\text { obtain PnAg in the form of white } \\
\text { solid powder. By this protocol, } \\
\text { the yield of PnAg can reach } 50 \% \text {. }\end{array}$ & $\begin{array}{l}\text { PnAg could promote wound healing in } \\
\text { SD rats and Bama minipigs with low } \\
\text { scar formation. The study illustrated } \\
\text { the desirable efficacy, low toxicity, and } \\
\text { negligible blood enrichment of PnAg } \\
\text { during wound healing. }\end{array}$ \\
\hline
\end{tabular}




\section{Working Hypothesis}

The proposed study will test the hypothesis that topical application of PHT will accelerate and improve the wound healing trajectory of experimental palatal gingival wounds in humans.

\section{Specific aims:}

1. To assess the clinical effects of a topical PHT formulation on healing of experimental palatal wounds.

2. Help gather new information on post-harvesting palatal wound morbidity, on the possible patient centered outcomes of topical PHT as a postoperative wound treatment protocol, and on the molecular effects of PHT on gingival tissues. 
Chapter 2. Materials and Methods

\section{Experimental design}

This study was performed as a prospective split-mouth experimental clinical trial.

Systemically healthy, non-smoking adults were recruited. Two standardized wounds (one posterior and one anterior), were created on both sides of the palate using custom stents and biopsy punches. Wounds on one randomly chosen side received Phenytoin formulation (test) and on the other received carrier alone (control). Participants were blinded to treatment allocation. Biopsies were harvested from the anterior wounds, either on Day 1 (Group 1) or on Day 5 (Group 2), and were routinely processed for histology (H\&E, Masson trichrome), and immunohistochemistry. Posterior undisturbed wounds were used to evaluate clinical healing (using photographs and Healing Score Index) on postoperative Day 1, 5, 14 and 21. Oral Health Impact Profile-14 (OHIP-14) and questionnaires were used to evaluate patient centered outcomes. Histomorphometry was performed on both H\&E and Masson-stained sections. Study participants provided signed informed consent and were reimbursed for participation. The study protocol, informed consent, study forms and questionnaires were approved by the Institutional Review Board of The Ohio State University (Protocol \#2018H0323). All clinical procedures were performed at the Graduate Periodontology Clinic, OSU College of Dentistry. 


\section{$\underline{\text { Study population and overall design }}$}

Periodontally and systemically healthy adults, aged 21-38 years (age limits were placed because of evidence of delayed wound healing in older adults ${ }^{44}$ ), were included. Based on sample size calculations (see power analysis below in Chapter 3), and to have adequate sample numbers for the subsequent laboratory investigations, a total of 20 participants were recruited for this study. The participants were divided into two equal groups based on biopsy timing: 10 participants were randomly allocated to Group 1, whose members were biopsied on postoperative Day 1 ( $24 \pm 4$ hours), and 10 participants were randomly allocated to Group 2, whose members were biopsied on postoperative Day 5

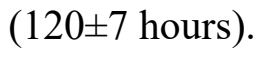

During telephone screening and at initial visit, the participants were assessed for the following additional inclusion criteria:

a) Systemic factors: no systemic diseases; no coagulation disorders; no medications affecting periodontal status in the previous 6 months; no pregnancy or lactation or contraceptive medication use; no allergy to study medications;

b) Behavioral factors: no tobacco or marijuana use; exhaled air carbon monoxide $<8$ ppm.

c) Dental and periodontal factors: no untreated caries lesions, inadequate endodontic therapy or tooth mobility $>1$ on maxillary teeth; no untreated periodontitis; full-mouth plaque score [FMPS] and full-mouth bleeding score $[\mathrm{FMBS}] \leq 20 \%$ at study entry; 
d) No previous periodontal surgery on the palatal masticatory mucosa; adequate mesio-distal (anteroposterior) arch length for required wound size and spacing.

e) Ability to tolerate maxillary impression making and use of palatal template, i.e., lack of strong gag reflex;

f) No contraindication to receiving PHT, other study medications (anesthetics and analgesics), or gingival surgery.

Subjects were recruited through flyers, announcements and advertisements in the OSU College of Dentistry. All participants, that met all inclusion criteria, had their maxillary arch impressions made prior to their first surgical visit to construct two custom templates (palatal stents) - one for using postoperatively to minimize discomfort and the other to standardized experimental wound size and site on both sides of the palate and to obtain a post-operative tissue biopsy. Surgical stents (Figure 2A) were made with thermoplastic splint material with two holes on each side $5 \mathrm{~mm}$ apart (between the distal part of canine and the distal part of first molar; $3 \mathrm{~mm}$ from the palatal gingival margin). The holes served as a guide for biopsy punches with a diameter of either $6 \mathrm{~mm}$ (posterior wound) or $4 \mathrm{~mm}$ (anterior wound). The anterior $4 \mathrm{~mm}$ holes in the surgical stents were modified to $6 \mathrm{~mm}$ holes after initial wounding day to guide the $6 \mathrm{~mm}$ biopsy punch for biopsy day. Customized post-operative stents (Figure 2B) were made with self-cure Orthodontic resin covering the entire palatal surface and embrasures, with $0.7 \mathrm{~mm}$ ball clasps in the buccal embrasures between maxillary canines and lateral incisors for additional retention. 


\section{Surgical procedures}

Vital signs were obtained at the screening appointment and prior to all surgical procedures. Surgical procedures, i.e., wound creation and biopsy harvest, were conducted following achievement of topical and local anesthesia. First, one side of the palate was dried with a sterile gauze followed by topical anesthetic ( $20 \%$ benzocaine) application with a cotton applicator for two minutes, over the area corresponding to the greater palatine foramen. Once located, sufficient pressure was applied to blanch the tissue for 30 seconds. Greater palatine block anesthesia was then performed using $1 / 4$ to $1 / 3$ cartridge of 2\% lidocaine with 1: 100,000 epinephrine. If needed, additional infiltration anesthesia was performed in the canine-premolar area using $1 / 4$ to $1 / 3$ cartridge of $2 \%$ lidocaine with 1: 100,000 epinephrine. Same anesthetic protocol was followed on the contralateral side of the palate. Wounding procedure was commenced after 3-5 minutes, once both subjective and objective symptoms of adequate anesthesia had been verified.

The day of wound creation was considered study Day 0 . One $6 \mathrm{~mm}$ diameter wound (distal/posterior site) and one $4 \mathrm{~mm}$ wound (mesial/anterior site), both to $1.5 \mathrm{~mm}$ depth, were created on both sides of the palate using single-use biopsy punches and the surgical stent described above (Figure 3). To standardize depth, the biopsy punches were marked with a sterile adhesive tape $1.5 \mathrm{~mm}$ short of the cutting edge (Figure $2 \mathrm{C}$ ). The space between the adjoining borders (perimeter) of the two wounds was standardized to 5 $\mathrm{mm}$. Posterior (6 $\mathrm{mm}$ diameter) wounds were used to evaluate clinical wound healing and left undisturbed, except for reapplication of treatment, for the duration of the study. The anterior ( $4 \mathrm{~mm}$ diameter) wounds were used subsequently for biopsy harvest. The total surface area of the two experimental wounds, per palatal side, was approximately $41 \mathrm{~mm}^{2}$ 
$\left(28.3 \mathrm{~mm}^{2}+12.6 \mathrm{~mm}^{2}\right)$. For comparison purposes, a typical graft harvest from the palate, used for treatment purposes, results in the formation of a wound with a surface area of $\geq 90 \mathrm{~mm}^{245}$. The healthy tissues excised by the punches for wound creation were harvested for histological, immunohistochemical and gene expression studies (immunohistochemistry and gene expression analyses will not be included in this work and will be reported elsewhere). These Day 0 tissue samples were used to represent the baseline/homeostatic condition of the palatal mucosa. Both wounds on the same side of the palate received the same treatment. Following creation of the wounds, treatment selection was randomly assigned by using sealed opaque envelopes marked with treatment allocation sides: Right/Left. Accordingly, one side of the palate received PHT and the other received the carrier alone (poloxamer gel) (Figure 2D).

PHT formulation was prepared by a local commercial compounding pharmacy as $10 \%$ Phenytoin USP in a $30 \%$ poloxamer gel. PHT was locally applied to the wounds at a dose of $10 \mathrm{mg} / 0.1 \mathrm{ml}$ to each site. This formulation, with an estimated total wound volume of $\leq 0.11 \mathrm{ml}$, resulted in the delivery of $\leq 12 \mathrm{mg}$ of PHT per patient per application. Participants received a total of three (3) local PHT applications, one on Day 0, one on Day 1, and one on Day 5; therefore, participants received a grand total of $\leq 50 \mathrm{mg}$ of locally applied PHT over the course of five days. With an estimated surface area of 28.3 $\mathrm{mm}^{2}$, the $6 \mathrm{~mm}$ diameter wound received $18 \mathrm{mg} \mathrm{PHT} / \mathrm{cm}^{2}$. This PHT dose per unit surface area was similar to the dose that has been locally applied in other studies reporting positive outcomes in humans ${ }^{20,46}$.

Biopsies: Besides the aforementioned harvest of the tissues excised for wound creation (Day 0), biopsies during wound healing were obtained either on postoperative 
Day 1 (Group 1) or on Day 5 (Group 2). Biopsies were harvested under local anesthesia, as described above, from the anterior ( $4 \mathrm{~mm}$ diameter) wound, using a $6 \mathrm{~mm}$ biopsy punch (with depth indicator tape). The punch was placed concentrically over the wound, using the modified surgical stent as described above (Figure 4). Group allocation (Group 1 or Group 2) was randomly performed, by sealed envelope, at the screening visit, after verifying eligibility and obtaining consent to participate. Harvested biopsies were immediately sectioned in two halves, with one half stored in RNAlater ${ }^{\circledR}$ (InvitrogenTM, Thermo Fisher Scientific, Carlsbad, CA, USA) for gene expression analysis and the other stored in 10\% neutral buffered formalin) for histological analysis and immunohistochemistry.

Participants received all study procedures and medications at no charge. All eligible and consented study participants were compensated for their study time for all study visits (Screening Day, Day 0, Day 1, Day 5, Day 14, and Day 21). The maximum possible compensation for the entire duration of the study was $\$ 360$.

\section{$\underline{\text { Postoperative protocol }}$}

Following wound creation and treatment application, participants received custom-made palatal stents (described above; Figure 2B) to minimize post-operative discomfort. Participants were instructed to not eat or drink anything for up to 4 hours each time after the application of the treatments and not use any mouth rinses or any other special home care aids other than the standard oral hygiene measures. They also received routine postoperative instructions for graft harvesting (Figures 5-6). For clinical assessments, the participants were recalled on postoperative Day 1 ( $24 \pm 4$ hours), 5 (120 
\pm 7 hours), 14 (336 \pm 8 hours) and 21 (21 1 day) (See Figure 1). Acetaminophen 325$650 \mathrm{mg}$ PO q4hr PRN was prescribed (given) to the participants. Participants were also prescribed ibuprofen $(600 \mathrm{mg})$ to be used as rescue medication, if needed.

\section{$\underline{\text { Clinical assessments }}$}

The following assessments were performed in the order described.

a) Healing Score Index: The Pippi modification ${ }^{47}$ of the Landry index ${ }^{48}$ was used to evaluate clinical healing; the following evaluation parameters were scored for each posterior wound by applying a dichotomic score (0/1) with a possible total score of 7 :

presence/absence of redness; presence/absence of granulation tissue;

presence/absence of suppuration; presence/absence of swelling; degree of tissue epithelialization (partial/complete); presence/absence of bleeding; presence/absence of pain on palpation. The Healing Score Index was assessed on postoperative Day 1, 5,14 , and 21 .

b) Time needed to obtain complete re-epithelialization of the palatal wound (CWE) was evaluated clinically by visual assessment (photographs) and the peroxide test.

i. Visual assessment: Wound size was captured by photography of the wounds (at each post-operative visit) with a standard-sized sterile paper label temporarily placed adjacent to the wound so as to account for magnification and angulation errors (Figure 25). The photographic images, captured at completion of wounding procedure (Day 0) and on postoperative Day 1, 5, 14, and 21, were analyzed by image analysis computer software (ImageJ, NIH, Bethesda, MD). 
ii. Peroxide test: The test was performed on postoperative days 14 and 21 . After drying the area to be evaluated with a gentle stream of air, $3 \% \mathrm{H}_{2} \mathrm{O}_{2}$ was sprinkled on the wounds with a syringe. The appearance of bubbles suggested that the surgical site was not completely epithelialized. CWE was recorded as a dichotomous variable (yes/no).

\section{$\underline{\text { Patient centered outcomes }}$}

a) Custom Questionnaires: these included a visual analog scale (VAS), used to assess pain experience, and questions related to analgesics used and postoperative complications experienced (See Figures 7-19)

b) OHIP-14: Participants were asked to complete the Oral Health Impact Profile-14 (OHIP-14) questionnaire, which was used to assess the subjective social impact that an oral condition makes on a person's well-being (See Figures 20-24).

All questionnaires were given to the participants at the start of each postoperative visit on Day 1, 5, 14, and 21. The OHIP-14 questionnaire was also given to the participants at the start of study, Day 0 (day of wounding procedure), to establish baseline status.

Histology

10 specimens randomly selected, 5 from Group 1 and 5 from Group 2, were processed for histological evaluation. The formalin treated specimens were embedded in paraffin and further processed for routine histology ( $4 \mu \mathrm{m}$ sections obtained from the midline of the harvested biopsy). Slides were stained with $\mathrm{H} \& \mathrm{E}$ and Masson trichrome 
(Agilent Dako kit, catalog\# AR17311-2). Histology specimen processing was done at the OSU Pathology Facility. Slides were examined by light microscopy. 


\begin{tabular}{|c|c|c|c|c|c|c|}
\hline \multicolumn{7}{|c|}{ TIMELINE } \\
\hline \multirow[b]{2}{*}{ STUDY VISITS } & Visit 0 & Visit 1 & Visit 2 & Visit 3 & Visit 4 & Visit 5 \\
\hline & Initial & $\begin{array}{c}\text { Day 0 } \\
\text { (Wounding) }\end{array}$ & $\begin{array}{c}\text { Day } 1 \\
(24 \pm 4 \text { hrs })\end{array}$ & $\begin{array}{c}\text { Day 5 } \\
(120 \pm 7 \text { hrs })\end{array}$ & $\begin{array}{c}\text { Day 14 } \\
(336 \pm 8 \text { hrs })\end{array}$ & $\begin{array}{c}\text { Day } 21 \\
(21 \pm 1 \text { day }) \\
\end{array}$ \\
\hline \multicolumn{7}{|l|}{ ENROLMENT } \\
\hline Eligibility Screening & $x$ & & & & & \\
\hline Informed consent & $x$ & & & & & \\
\hline Vital Signs & $x$ & $x$ & Group 1 & Group 2 & & \\
\hline Maxillary Impression & $x$ & & & & & \\
\hline $\begin{array}{l}\text { Biopsy Group Allocation } \\
\text { (Group 1/ Group 2) }\end{array}$ & $x$ & & & & & \\
\hline $\begin{array}{l}\text { Tx side selection } \\
\text { (Right/ Left) }\end{array}$ & & $x$ & & & & \\
\hline \multicolumn{7}{|l|}{ INTERVENTIONS } \\
\hline Wound creation & & $x$ & & & & \\
\hline Carrier/PHT Application & & $x$ & $x$ & $x$ & & \\
\hline BIOPSY harvest & & & Group 1 & Group 2 & & \\
\hline \multicolumn{7}{|l|}{ ASSESMENTS } \\
\hline \multicolumn{7}{|l|}{ Clinical: } \\
\hline Healing Score Index & & & $x$ & $x$ & $x$ & $x$ \\
\hline Photograph & & $x$ & $x$ & $x$ & $x$ & $x$ \\
\hline Peroxide test & & & & & $x$ & $x$ \\
\hline \multicolumn{7}{|l|}{ Patient centered: } \\
\hline Custom Questionnaires & & & $x$ & $x$ & $x$ & $x$ \\
\hline OHIP-14 & & $x$ & $x$ & $x$ & $x$ & $x$ \\
\hline
\end{tabular}

Figure 1. Study Design 


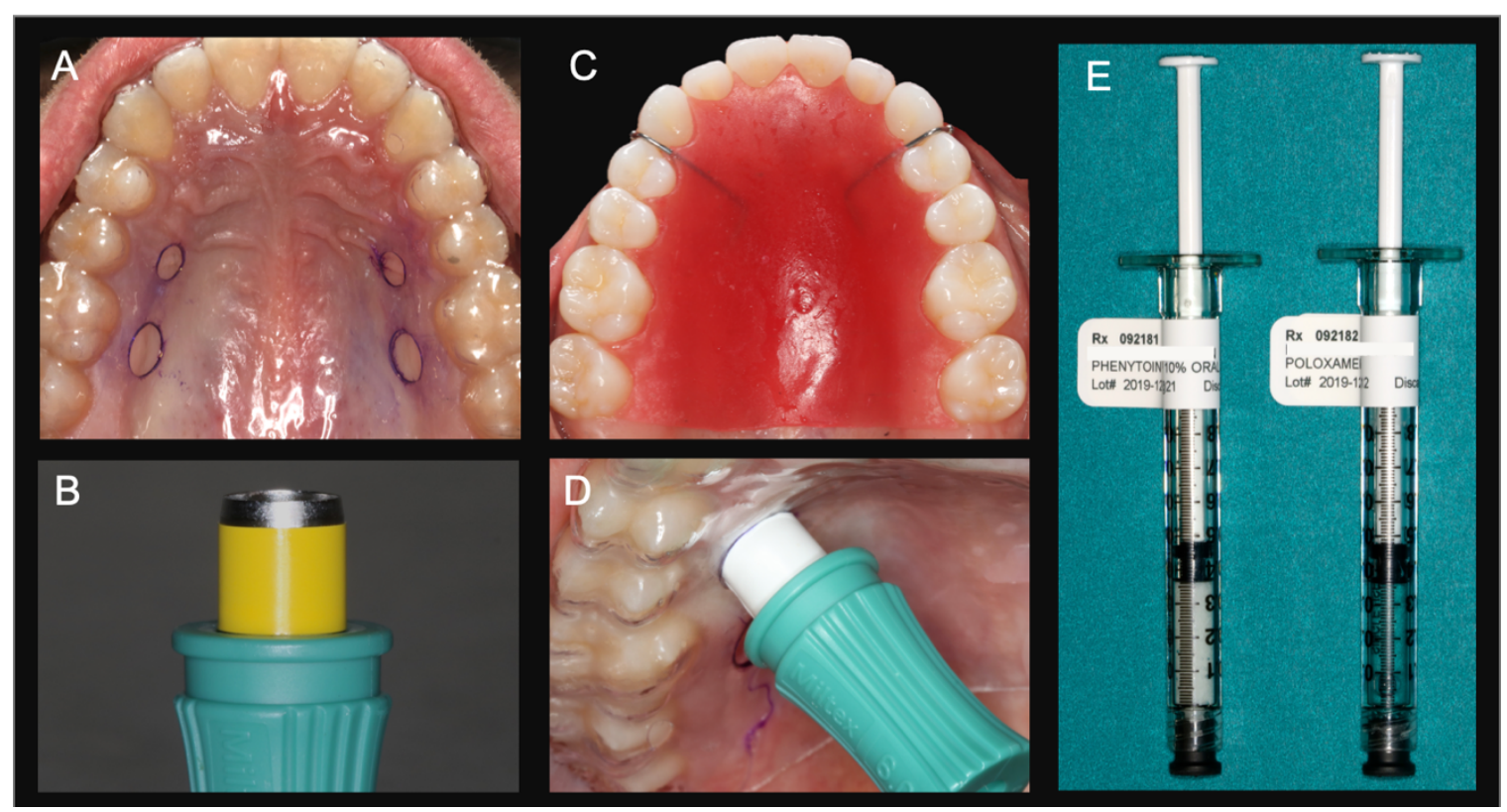

Figure 2. Surgical stent (A), Biopsy Punch with depth indicator (B), Post-operative stent (C), Wounding procedure (D) Phenytoin and Poloxamer gel delivery syringes (E) 


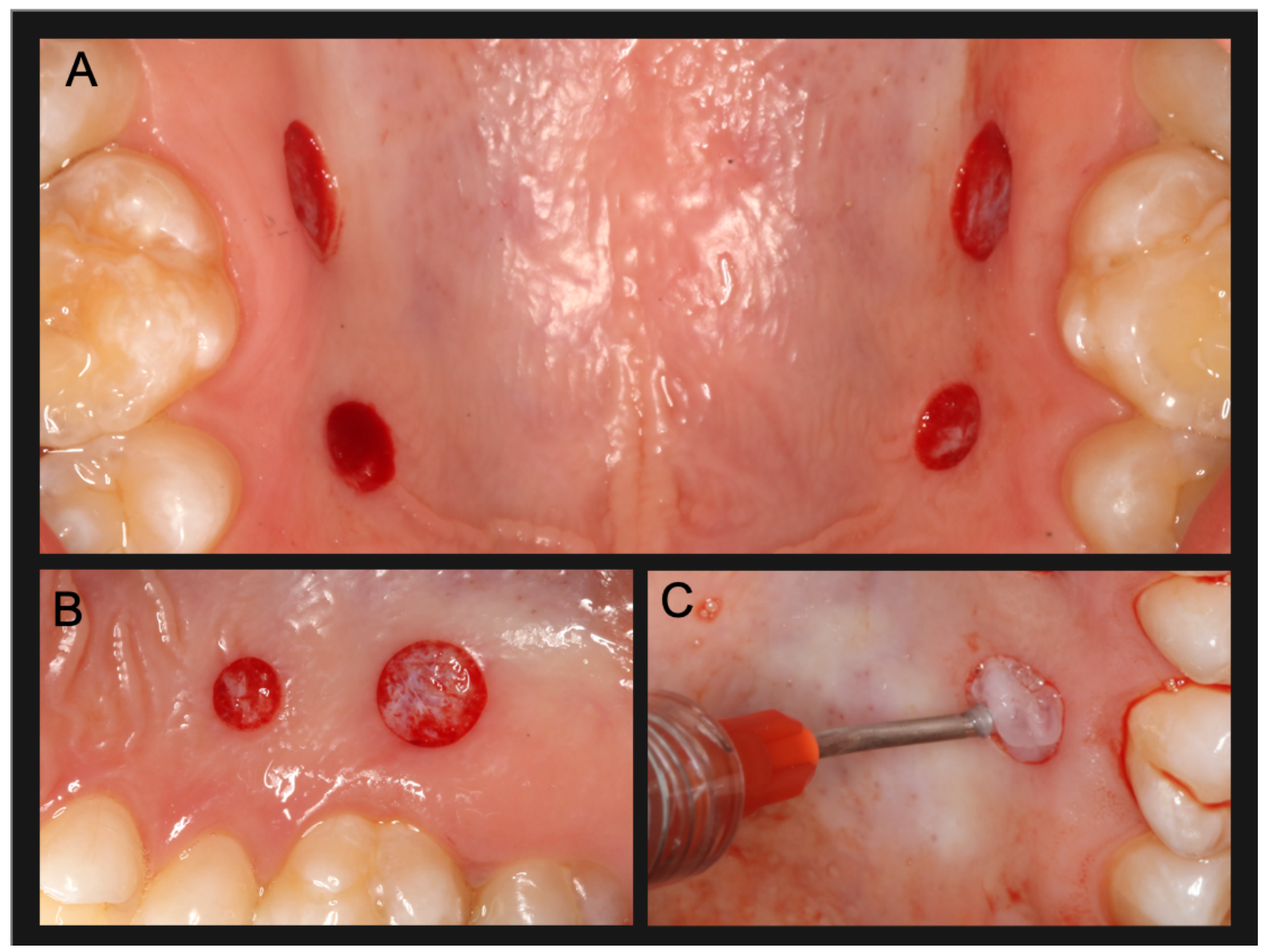

Figure 3. A) Occlusal view of bilateral $6 \mathrm{~mm}$ diameter posterior wounds and $4 \mathrm{~mm}$ diameter anterior wounds. B) Palatal view of both wounds. C) Phenytoin application. 


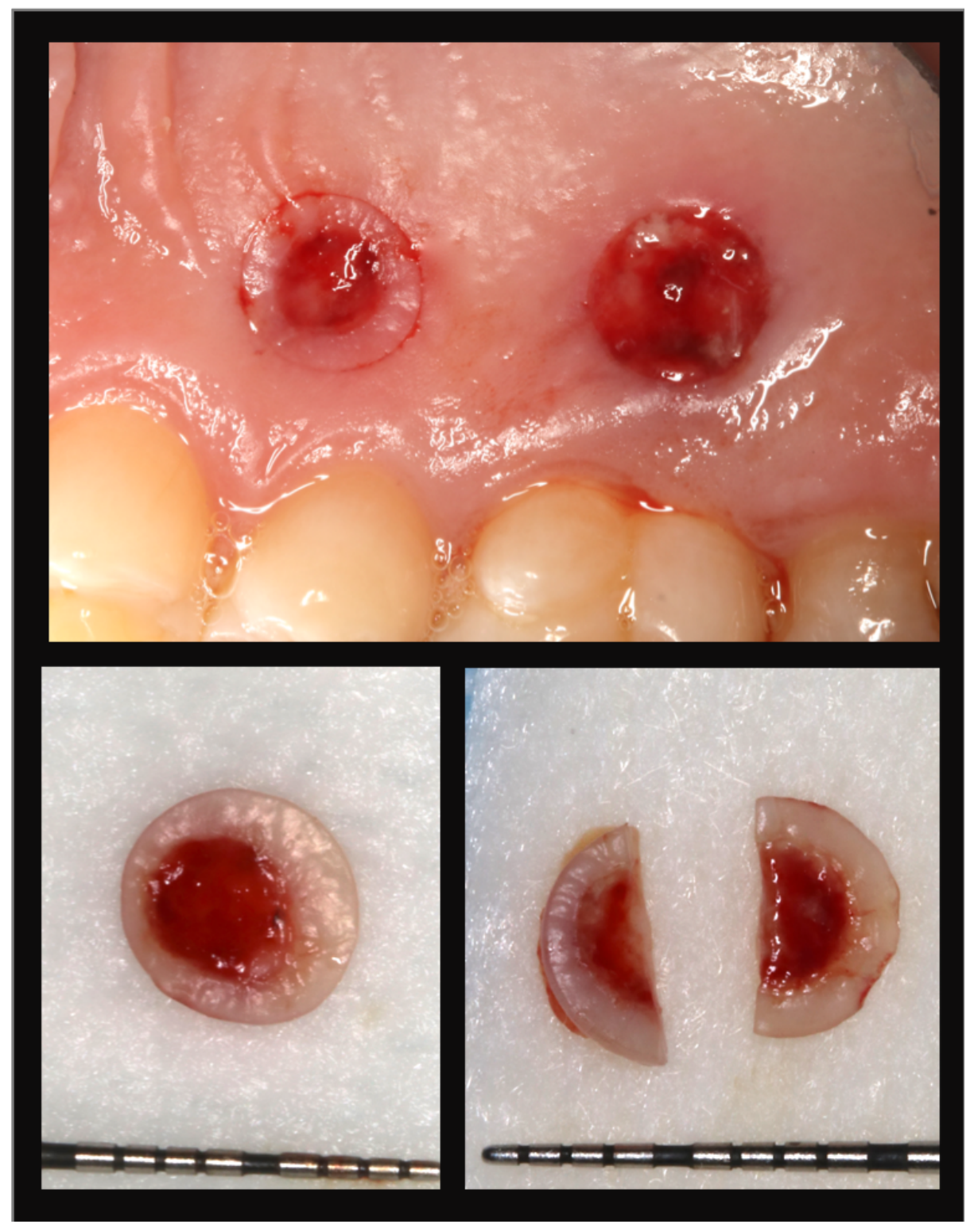

Figure 4.A) Circumferential punch incision (6 mm diameter) around the anterior wound (Day 1). B) Gross specimen of punch biopsy harvest. C) Biopsy harvest sectioned in two 
The Ohio State University

College of Dentistry

Graduate Periodontics Clinic

\section{POST - OPERATIVE INSTRUCTIONS}

Please follow these instructions in caring for your mouth. Periodontal post-operative complications are uncommon. However, do not hesitate to contact us should any problem arise.

\section{Telephone Numbers:}

Graduate Periodontics Clinic: (614) 292-4927

Monday, Wednesday - Friday: 8:30 - 11:30 AM and 1:00 - 4:30 PM

Your Graduate Periodontal doctor's direct number is:

If you cannot reach your periodontal doctor, please call the periodontal resident on call at: (614) 731-2669 (EMERGENCY pager number).

Do's and Don'ts:

\section{POST - OPERATIVE INSTRUCTIONS}

- Avoid eating or drinking any hot foods or hot beverages for the remainder of the day following the wounding procedure.

- Avoid spicy or crusty foods such as toast crust, nuts or chips during the entire study period.

- Do NOT use any mouthrinse or any other special homecare aids during the entire study period.

- Wear the custom-made stent as instructed below

- Do NOT use any tobacco or tobacco related product during the entire study period

- Avoid consuming alcohol during the entire study period

NUMBNESS - 'TINGLING': The local anesthetic may persist 2 -10 hours after the procedure. Be careful to not hurt the roof of your mouth. Avoid eating until all the anesthesia (numbness) has worn off. Very rarely you may experience transient numbness or altered sensation at the roof of your mouth. This may last a few days, rarely a few weeks, and more rarely a few months.

PAIN MEDICATION: Take the pain medication that has been given to you only as needed. Please take the given Acetaminophen (325mg) 1-2 tablets every 4 to 6 hours while symptoms last, not exceeding more than 10 tablets $(3250 \mathrm{mg})$ in a 24-hour period. Do NOT exceed a maximum single dose of 650 $\mathrm{mg}$ ( 2 tablets). If the acetaminophen pills do not provide adequate pain relief, then you can take the prescribed ibuprofen $(600 \mathrm{mg})$ medication every 4 to 6 hours. Do NOT exceed the maximum daily dose of 5 tablets or $3000 \mathrm{mg}$. If the pain persists or gets worse contact our clinic.

Figure 5. Post-operative instructions, Page 1 
BLEEDING: You may see blood in your saliva for a day or two after surgery. This is normal and usually ends naturally by the third day. If oozing persists, gently compress the roof of your mouth with a moistened gauze for 20-30 minutes. You may have to repeat this process. If bleeding persists, call us. Avoid eating or drinking any hot foods or hot beverages for the remainder of the day following your procedure; heat can cause bleeding to start or increase.

SWELLING: You may also experience a little localized swelling in the wound area; this typically will subside after 3-4 days. Should swelling continue to worsen beyond 3 days, contact us. It is very rare to experience an infection after this kind of procedure. In the unlikely event you experience an infection, you will be given a prescription for antibiotic medication.

PLASTIC STENT: Please wear the custom-made stent given to you to protect the wounds on the roof of your mouth. Wear it full time for the first week and during the second week, only when eating. It is important that you remove and clean your stent daily with plain water, cleaning after meals is highly recommended. If you are bleeding from the palate, place your thumb on the stent and apply strong pressure as mentioned above.

ORAL HYGIENE. You may brush and floss all your teeth making sure you avoid the wounded palatal area. Do not use any mouthrinse or any other special homecare aids during the entire study period.

EATING. Eat soft foods for a few days following wounding procedure. Avoid hot, spicy or crusty foods such as toast crust, nuts or chips during the entire study period. Drink plenty of fluids.

SMOKING and ALCOHOL: Do not use any tobacco product for the entire study period. Use of tobacco or any tobacco related product will lead to termination of your participation in the study. Smoking delays healing and there are more post-operative complications in smokers. Avoid consuming alcohol for the entire studv period. If you do consume alcohol please notify us at your next follow up visit. Alcohol can cause an adverse reaction with medications provided to assist in healing and discomfort.

PHYSICAL ACTIVITY. Avoid strenuous exercise or other demanding physical activity for the first 48 hours after wounding procedure.

Figure 6. Post-operative instructions, Page 2 
STUDY SUBJECT \#

Palatal Wound Healing: Phenytoin Effects (Doshi \& Tatakis) -Q PoDI

\section{QUESTIONNAIRE \\ STUDY VISIT 2 - Post-Op DAY 1}

Date Completed

Please answer as best you can. If you would like an explanation, please feel free to ask. Your answers are strictly confidential and will remain anonymous.

1. Which of the two sides, right or left, experienced more pain since your last visit?

$\square$ The right side
The left side
Both sides felt the same

THE QUESTIONS IN THE BOX BELOW ARE ABOUT THE RIGHT SIDE OF YOUR MOUTH

2. Did you have any pain on this side since your last visit? ___ Yes__ No

If yes, please describe the pain as best you can (for example: throbbing, stabbing, sharp, dull, duration, etc...)

3. How much pain did you have? Please put a mark anywhere on the horizontal line below to indicate the level of pain; keep in mind that ' 0 ' means no pain and ' 10 ' means the most severe pain imaginable.

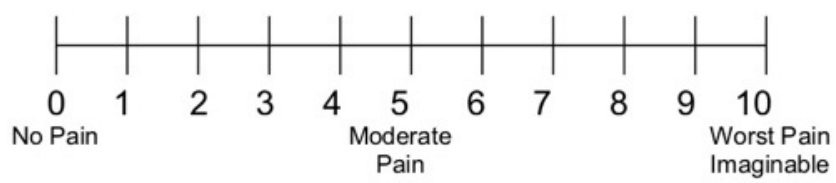

4. Please circle the number that best describes the pain that you experienced and how it affected your activities

$0=$ No pain

$1=$ Tolerable and pain does not prevent any activities

$2=$ Tolerable and pain prevents some activities

$3=$ Intolerable and pain does not prevent use of telephone, TV viewing, or reading

$4=$ Intolerable and pain prevents use of telephone, TV viewing, or reading

$5=$ Intolerable and pain prevents verbal communication.

If you experienced pain that you rated 2 or higher, please list or describe all the activities that were prevented by the pain:

Please continue the questionnaire on the next page

VERSION 1.0 Page 1 of 3

Figure 7. Post-Operative Day 1 Questionnaire, Page 1 


\section{THE QUESTIONS IN THE BOX BELOW ABOUT THE LEFT SIDE OF YOUR MOUTH}

5. Did you have any pain on this side since your last visit? Yes No

If yes, please describe the pain as best you can (for example: throbbing, stabbing, sharp, dull, duration, etc...)

6. How much pain did you have? Please put a mark anywhere on the horizontal line below to indicate the level of pain; keep in mind that ' 0 ' means no pain and ' 10 ' means the most severe pain imaginable.

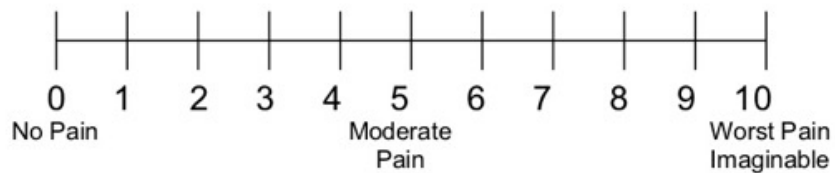

7. Please circle the number that best describes the pain that you experienced and how it affected your activities

$0=$ No pain

$1=$ Tolerable and pain does not prevent any activities

2 = Tolerable and pain prevents some activities

$3=$ Intolerable and pain does not prevent use of telephone, TV viewing, or reading

4 = Intolerable and pain prevents use of telephone, TV viewing, or reading

$5=$ Intolerable and pain prevents verbal communication.

If you experienced pain that you rated 2 or higher, please list or describe all the activities that were prevented by the pain:

8. Did you take any of the pain medication since your last visit?

Yes

No

If yes, please indicate below what, when, how much, and how often you took it:

\begin{tabular}{l|l|l|l|}
\multicolumn{1}{c}{ Medication (name) } & $\begin{array}{c}\text { When taken } \\
\text { (Day/Date/Time) }\end{array}$ & $\begin{array}{c}\text { Amount taken } \\
\text { (Number of pills) }\end{array}$ & $\begin{array}{c}\text { How often taken } \\
\text { (example: twice a day) }\end{array}$ \\
\hline & & & \\
\hline & & & \\
\hline & & & \\
\hline & & & \\
\hline
\end{tabular}

Please continue the questionnaire on the next page

VERSION 1.0 Page 2 of 3

Figure 8. Post-Operative Day 1 Questionnaire, Page 2 
9. Did you use the stent made for you since vour last visit? ___ Yes ___ No If yes, how much and how often did you use it?

10. Did you feel any discomfort (example: itching, tingling, altered sensation, numbness) from the wounds since the anesthesia wore off? Yes No

If yes, please describe the discomfort, when and how often you felt it:

If yes, the discomfort you felt from the wound was (Please circle one):

Only on the RIGHT side

Only on the LEFT side

On BOTH sides

11. Did you experience any bleeding from the wounds? Yes No If yes, please describe when and how often you experienced it:

If yes, the bleeding you experienced from the wound on the roof of your mouth was (Please circle one): Only on the RIGHT side Only on the LEFT side On BOTH sides

12. Did you have any swelling in the wound area? Yes No If yes, please describe when did it start and whether it prevented you from any activities:

If yes, the swelling you experienced in the wound on the roof of your mouth was (Please circle one): Only on the RIGHT side Only on the LEFT side On BOTH sides

\section{Thank you for completing this questionnaire}

VERSION $1.0 \quad$ Page 3 of 3

Figure 9. Post-Operative Day 1 Questionnaire, Page 3 
STUDY SUBJECT \#

Palatal Wound Healing: Phenytoin Effects (Doshi \& Tatakis) -Q PoD5

\section{QUESTIONNAIRE \\ STUDY VISIT 3 - Post-Op DAY 5}

Date Completed

Please answer as best you can. If you would like an explanation, please feel free to ask. Your answers are strictly confidential and will remain anonymous.

1. Which of the two sides, right or left, experienced more pain since your last visit?

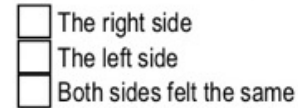

THE QUESTIONS IN THE BOX BELOW ARE ABOUT THE RIGHT SIDE OF YOUR MOUTH

2. Did you have any pain on this side since your last visit? ___ Yes____ No

If yes, please describe the pain as best you can (for example: throbbing, stabbing, sharp, dull, duration, etc...)

3. How much pain did you have? Please put a mark anywhere on the horizontal line below to indicate the level of pain; keep in mind that ' 0 ' means no pain and ' 10 ' means the most severe pain imaginable.

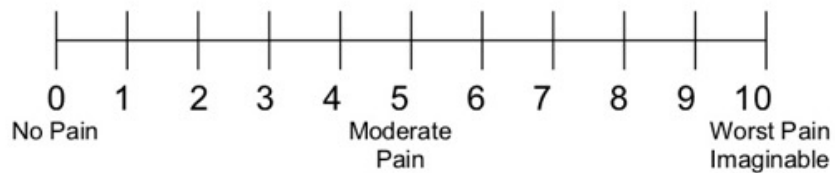

4. Please circle the number that best describes the pain that you experienced and how it affected your activities

$0=$ No pain

$1=$ Tolerable and pain does not prevent any activities

$2=$ Tolerable and pain prevents some activities

$3=$ Intolerable and pain does not prevent use of telephone, TV viewing, or reading

$4=$ Intolerable and pain prevents use of telephone, TV viewing, or reading

$5=$ Intolerable and pain prevents verbal communication.

If you experienced pain that you rated 2 or higher, please list or describe all the activities that were prevented by the pain:

Please continue the questionnaire on the next page

VERSION $1.0 \quad$ Page 1 of 3

Figure 10. Post-Operative Day 5 Questionnaire, Page 1 


\section{THE QUESTIONS IN THE BOX BELOW ABOUT THE LEFT SIDE OF YOUR MOUTH}

5. Did you have any pain on this side since your last visit? Yes No

If yes, please describe the pain as best you can (for example: throbbing, stabbing, sharp, dull, duration, etc...)

6. How much pain did you have? Please put a mark anywhere on the horizontal line below to indicate the level of pain; keep in mind that ' 0 ' means no pain and ' 10 ' means the most severe pain imaginable.

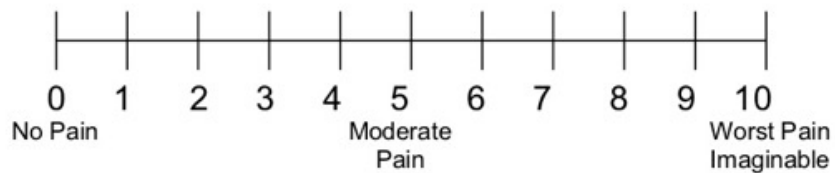

7. Please circle the number that best describes the pain that you experienced and how it affected your activities

$0=$ No pain

$1=$ Tolerable and pain does not prevent any activities

$2=$ Tolerable and pain prevents some activities

$3=$ Intolerable and pain does not prevent use of telephone, TV viewing, or reading

$4=$ Intolerable and pain prevents use of telephone, TV viewing, or reading

$5=$ Intolerable and pain prevents verbal communication.

If you experienced pain that you rated 2 or higher, please list or describe all the activities that were prevented by the pain:

8. Did you take any of the pain medication since your last visit?

Yes

No

If yes, please indicate below what, when, how much, and how often you took it:

\begin{tabular}{c|c|c|c|}
\multicolumn{1}{c}{ Medication (name) } & $\begin{array}{c}\text { When taken } \\
\text { (Day/Date/Time) }\end{array}$ & $\begin{array}{c}\text { Amount taken } \\
\text { (Number of pills) }\end{array}$ & $\begin{array}{c}\text { How often taken } \\
\text { (example: twice a day) }\end{array}$ \\
\hline & & & \\
\hline & & & \\
\hline & & & \\
\hline & & & \\
\hline
\end{tabular}

Please continue the questionnaire on the next page

VERSION 1.0 Page 2 of 3

Figure 11. Post-Operative Day 5 Questionnaire, Page 2 
9. Did you use the stent made for you since your last visit? ___ Yes ___ No If yes, how much and how often did you use it?

10. Did you feel any discomfort (example: itching, tingling, altered sensation, numbness) from the wounds since your last visit? ___ Yes ___ No

If yes, please describe the discomfort, when and how often you felt it:

If yes, the discomfort you felt from the wound was (Please circle one):

Only on the RIGHT side

Only on the LEFT side

On BOTH sides

11. Did you experience any bleeding from the wounds since your last visit? Yes No If yes, please describe when and how often you experienced it:

If yes, the bleeding you experienced from the wound on the roof of your mouth was (Please circle one): Only on the RIGHT side Only on the LEFT side

On BOTH sides

12. Did you have any swelling in the wound area since your last visit? Yes No If yes, please describe when did it start and whether it prevented you from any activities:

If yes, the swelling you experienced in the wound on the roof of your mouth was (Please circle one): Only on the RIGHT side

Only on the LEFT side

On BOTH sides

Thank you for completing this questionnaire

VERSION 1.0 Page 3 of 3

Figure 12. Post-Operative Day 5 Questionnaire, Page 3 
STUDY SUBJECT \#

\section{QUESTIONNAIRE \\ STUDY VISIT 4 - Post-Op DAY 14}

Date Completed

Please answer as best you can. If you would like an explanation, please feel free to ask. Your answers are strictly confidential and will remain anonymous.

1. Which of the two sides, right or left, experienced more pain since your last visit?

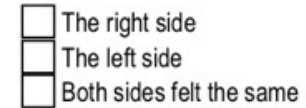

THE QUESTIONS IN THE BOX BELOW ARE ABOUT THE RIGHT SIDE OF YOUR MOUTH

2. Did you have any pain on this side since your last visit? ___ Yes__ _ No

If yes, please describe the pain as best you can (for example: throbbing, stabbing, sharp, dull, duration, etc...)

3. How much pain did you have? Please put a mark anywhere on the horizontal line below to indicate the level of pain; keep in mind that ' 0 ' means no pain and ' 10 ' means the most severe pain imaginable.

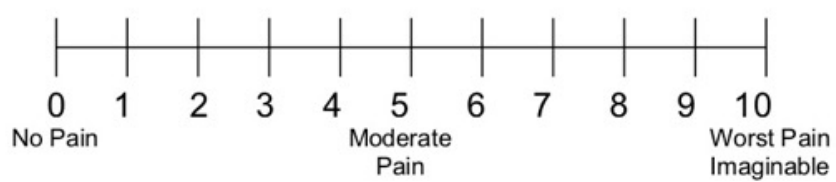

4. Please circle the number that best describes the pain that you experienced and how it affected your activities

$0=$ No pain

$1=$ Tolerable and pain does not prevent any activities

$2=$ Tolerable and pain prevents some activities

$3=$ Intolerable and pain does not prevent use of telephone, TV viewing, or reading

$4=$ Intolerable and pain prevents use of telephone, TV viewing, or reading

$5=$ Intolerable and pain prevents verbal communication.

If you experienced pain that you rated 2 or higher, please list or describe all the activities that were prevented by the pain:

Please continue the questionnaire on the next page

VERSION 1.0 Page 1 of 3

Figure 13. Post-Operative Day 14 Questionnaire, Page 1 
STUDY SUBJECT \#

THE QUESTIONS IN THE BOX BELOW ABOUT THE LEFT SIDE OF YOUR MOUTH

5. Did you have any pain on this side since your last visit? ___ Yes___ No

If yes, please describe the pain as best you can (for example: throbbing, stabbing, sharp, dull, duration,

etc...)

6. How much pain did you have? Please put a mark anywhere on the horizontal line below to indicate the level of pain; keep in mind that ' 0 ' means no pain and ' 10 ' means the most severe pain imaginable.

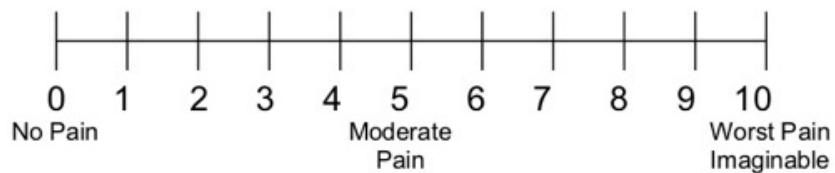

7. Please circle the number that best describes the pain that you experienced and how it affected your activities

$0=$ No pain

$1=$ Tolerable and pain does not prevent any activities

$2=$ Tolerable and pain prevents some activities

$3=$ Intolerable and pain does not prevent use of telephone, TV viewing, or reading

$4=$ Intolerable and pain prevents use of telephone, TV viewing, or reading

$5=$ Intolerable and pain prevents verbal communication.

If you experienced pain that you rated 2 or higher, please list or describe all the activities that were prevented by the pain:

8. Did you take any of the pain medication since your last visit?

Yes

No

If yes, please indicate below what, when, how much, and how often you took it:

\begin{tabular}{c|c|c|c|}
\multicolumn{1}{c}{ Medication (name) } & $\begin{array}{c}\text { When taken } \\
\text { (Day/Date/Time) }\end{array}$ & $\begin{array}{c}\text { Amount taken } \\
\text { (Number of pills) }\end{array}$ & \multicolumn{1}{c}{$\begin{array}{c}\text { How often taken } \\
\text { (example: twice a day) }\end{array}$} \\
\hline & & & \\
\hline & & & \\
\hline & & & \\
\hline & & & \\
\hline
\end{tabular}

Please continue the questionnaire on the next page

VERSION 1.0 Page 2 of 3

Figure 14. Post-Operative Day 14 Questionnaire, Page 2 
9. Did you use the stent made for you since vour last visit? ___ Yes ___ No If yes, how much and how often did you use it?

10. Did you feel any discomfort (example: itching, tingling, altered sensation, numbness) from the wounds since your last visit? ___ Yes ___ No

If yes, please describe the discomfort, when and how often you felt it:

If yes, the discomfort you felt from the wound was (Please circle one):

Only on the RIGHT side

Only on the LEFT side

On BOTH sides

11. Did you experience any bleeding from the wounds since your last visit? Yes No If yes, please describe when and how often you experienced it:

If yes, the bleeding you experienced from the wound on the roof of your mouth was (Please circle one): Only on the RIGHT side

12. Did you have any swelling in the wound area since your last visit? Yes No

If yes, please describe when did it start and whether it prevented you from any activities:

If yes, the swelling you experienced in the wound on the roof of your mouth was (Please circle one): Only on the RIGHT side

Only on the LEFT side

On BOTH sides

Thank you for completing this questionnaire

VERSION 1.0 Page 3 of 3

Figure 15. Post-Operative Day 14 Questionnaire, Page 3 
STUDY SUBJECT \#

\section{QUESTIONNAIRE}

STUDY VISIT 5 - Post-Op DAY 21

Date Completed

Please answer as best you can. If you would like an explanation, please feel free to ask. Your answers are strictly confidential and will remain anonymous.

1. Which of the two sides, right or left, experienced more pain since your last visit?

$\square$ The right side
The left side
Both sides felt the same

THE QUESTIONS IN THE BOX BELOW ARE ABOUT THE RIGHT SIDE OF YOUR MOUTH

2. Did you have any pain on this side since your last visit? ___ Yes____ No

If yes, please describe the pain as best you can (for example: throbbing, stabbing, sharp, dull, duration,

etc...)

3. How much pain did you have? Please put a mark anywhere on the horizontal line below to indicate the level of pain; keep in mind that ' 0 ' means no pain and ' 10 ' means the most severe pain imaginable.

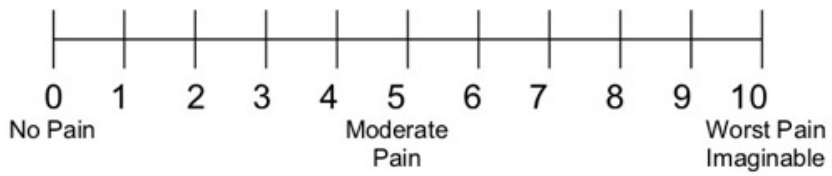

4. Please circle the number that best describes the pain that you experienced and how it affected your activities

$0=$ No pain

$1=$ Tolerable and pain does not prevent any activities

$2=$ Tolerable and pain prevents some activities

$3=$ Intolerable and pain does not prevent use of telephone, TV viewing, or reading

$4=$ Intolerable and pain prevents use of telephone, TV viewing, or reading

$5=$ Intolerable and pain prevents verbal communication.

If you experienced pain that you rated 2 or higher, please list or describe all the activities that were prevented by the pain:

Please continue the questionnaire on the next page

VERSION 1.0 Page 1 of 4

Figure 16. Post-Operative Day 21 Questionnaire, Page 1 
THE QUESTIONS IN THE BOX BELOW ABOUT THE LEFT SIDE OF YOUR MOUTH

5. Did you have any pain on this side since your last visit? ___ Yes___ No

If yes, please describe the pain as best you can (for example: throbbing, stabbing, sharp, dull, duration,

etc...)

6. How much pain did you have? Please put a mark anywhere on the horizontal line below to indicate the level of pain; keep in mind that ' 0 ' means no pain and '10' means the most severe pain imaginable.

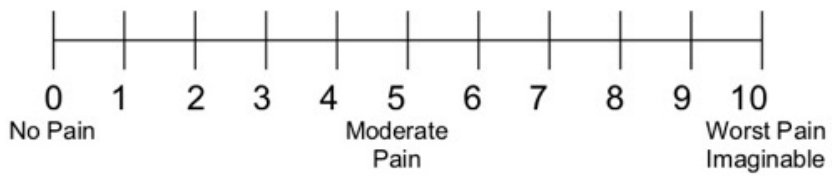

7. Please circle the number that best describes the pain that you experienced and how it affected your activities

0 No pain

1 = Tolerable and pain does not prevent any activities

$2=$ Tolerable and pain prevents some activities

$3=$ Intolerable and pain does not prevent use of telephone, TV viewing, or reading

4 = Intolerable and pain prevents use of telephone, TV viewing, or reading

$5=$ Intolerable and pain prevents verbal communication.

If you experienced pain that you rated 2 or higher, please list or describe all the activities that were prevented by the pain:

8. Did you take any of the pain medication since your last visit?

Yes

No

If yes, please indicate below what, when, how much, and how often you took it:

\begin{tabular}{|l|l|l|l|}
\multicolumn{1}{c}{ Medication (name) } & \multicolumn{1}{c}{$\begin{array}{c}\text { When taken } \\
\text { (Day/Date/Time) }\end{array}$} & $\begin{array}{c}\text { Amount taken } \\
\text { (Number of pills) }\end{array}$ & $\begin{array}{c}\text { How often taken } \\
\text { (example: twice a day) }\end{array}$ \\
\hline & & & \\
\hline & & & \\
\hline & & & \\
\hline & & & \\
\hline
\end{tabular}

Please continue the questionnaire on the next page

VERSION 1.0 Page 2 of 4

Figure 17. Post-Operative Day 21 Questionnaire, Page 2 
9. Did you use the stent made for you since vour last visit? ___ Yes ___ No If yes, how much and how often did you use it?

10. Did you feel any discomfort (example: itching, tingling, altered sensation, numbness) from the wounds since your last visit? ___ Yes ___ No

If yes, please describe the discomfort, when and how often you felt it:

If yes, the discomfort you felt from the wound was (Please circle one):

Only on the RIGHT side

Only on the LEFT side

On BOTH sides

11. Did you experience any bleeding from the wounds since your last visit? Yes No If yes, please describe when and how often you experienced it:

If yes, the bleeding you experienced from the wound on the roof of your mouth was (Please circle one): Only on the RIGHT side

12. Did you have any swelling in the wound area since your last visit? Yes No

If yes, please describe when did it start and whether it prevented you from any activities:

If yes, the swelling you experienced in the wound on the roof of your mouth was (Please circle one): Only on the RIGHT side

Only on the LEFT side

On BOTH sides

Please continue the questionnaire on the next page

VERSION $1.0 \quad$ Page 3 of 4

Figure 18. Post-Operative Day 21 Questionnaire, Page 3 
STUDY SUBJECT \#

Palatal Wound Healing: Phenytoin Effects (Doshi \& Tatakis) - Q PoD2I

13. How would you rank the experience of being in this study? (please circle one)

$\begin{array}{lllll}\text { Fantastic } & \text { Great } & \text { Average } & \text { Poor } & \text { Never Again }\end{array}$

14. Having had this experience, would you participate again in a similar study? (please circle one)

Yes, for sure $\quad$ Probably $\quad$ Maybe/not sure Probably not $\quad$ No way

15. Please tell us what, if anything, was worst about this study:

16. Please tell us what, if anything, was best about this study:

17. Please tell us any other comments or suggestions you might have about the study:

Thank you for completing this questionnaire and for taking part in this study

VERSION 1.0 Page 4 of 4

Figure 19. Post-Operative Day 21 Questionnaire, Page 4 


Palatal Wound Healing: Phenytoin Effects (Doshi \& Tatakis) - OHIP14 - Pretreatment
STUDY SUBJECT \#_ Date completed:

\section{OHIP-14}

Please read each statement and circle a number $0,1,2,3$ or 4 which indicates how much the statement applies to you. There are no right or wrong answers. Do not spend too much time on any statement.

The rating scale is as follows:

0 Never

1 Hardly ever

2 Occasionally

3 Fairly often

4 Very often

\begin{tabular}{|c|c|c|c|c|c|c|}
\hline 1 & $\begin{array}{l}\text { Have you had trouble pronouncing any words because of problems with your } \\
\text { teeth, mouth or dentures? }\end{array}$ & 0 & 1 & 2 & 3 & 4 \\
\hline 2 & $\begin{array}{l}\text { Have you felt that your sense of taste has worsened because of problems with } \\
\text { your teeth, mouth or dentures? }\end{array}$ & 0 & 1 & 2 & 3 & 4 \\
\hline 3 & Have you had painful aching in your mouth? & 0 & 1 & 2 & 3 & 4 \\
\hline 4 & $\begin{array}{l}\text { Have you found it uncomfortable to eat any foods because of problems with your } \\
\text { teeth, mouth or dentures? }\end{array}$ & 0 & 1 & 2 & 3 & 4 \\
\hline 5 & Have you been self-conscious because of your teeth, mouth or dentures? & 0 & 1 & 2 & 3 & 4 \\
\hline 6 & Have you felt tense because of problems with your teeth, mouth or dentures? & 0 & 1 & 2 & 3 & 4 \\
\hline 7 & $\begin{array}{l}\text { Has your diet been unsatisfactory because of problems with your teeth, mouth or } \\
\text { dentures? }\end{array}$ & 0 & 1 & 2 & 3 & 4 \\
\hline 8 & $\begin{array}{l}\text { Have you had to interrupt meals because of problems with your teeth, mouth or } \\
\text { dentures? }\end{array}$ & 0 & 1 & 2 & 3 & 4 \\
\hline 9 & $\begin{array}{l}\text { Have you found it difficult to relax because of problems with your teeth, mouth } \\
\text { or dentures? }\end{array}$ & 0 & 1 & 2 & 3 & 4 \\
\hline 10 & $\begin{array}{l}\text { Have you been a bit embarrassed because of problems with your teeth, mouth or } \\
\text { dentures? }\end{array}$ & 0 & 1 & 2 & 3 & 4 \\
\hline 11 & $\begin{array}{l}\text { Have you been a bit irritable with other people because of problems with your } \\
\text { teeth, mouth or dentures? }\end{array}$ & 0 & 1 & 2 & 3 & 4 \\
\hline 12 & $\begin{array}{l}\text { Have you had difficulty doing your usual jobs because of problems with your } \\
\text { teeth, mouth or dentures? }\end{array}$ & 0 & 1 & 2 & 3 & 4 \\
\hline 13 & $\begin{array}{l}\text { Have you felt that life in general was less satisfying because of problems with } \\
\text { your teeth, mouth or dentures? }\end{array}$ & 0 & 1 & 2 & 3 & 4 \\
\hline 14 & $\begin{array}{l}\text { Have you been totally unable to function because of problems with your teeth, } \\
\text { mouth or dentures? }\end{array}$ & 0 & 1 & 2 & 3 & 4 \\
\hline
\end{tabular}

Figure 20. OHIP-14 - Pretreatment 


Palatal Wound Healing: Phenytoin Effects (Doshi \& Tatakis) - OHIP14 - POD1
STUDY SUBJECT \# _ Date completed:

OHIP-14

Please read each statement and circle a number $0,1,2,3$ or 4 which indicates how much the statement applies to you over the last $\mathbf{2 4}$ hours (i.e., since the wounding procedure was performed). There are no right or wrong answers. Do not spend too much time on any statement.

The rating scale is as follows:

0 Never

1 Hardly ever

2 Occasionally

3 Fairly often

4 Very often

\begin{tabular}{|c|c|c|c|c|c|c|}
\hline 1 & $\begin{array}{l}\text { Have you had trouble pronouncing any words because of problems with your } \\
\text { teeth, mouth or dentures? }\end{array}$ & 0 & 1 & 2 & 3 & 4 \\
\hline 2 & $\begin{array}{l}\text { Have you felt that your sense of taste has worsened because of problems with } \\
\text { your teeth, mouth or dentures? }\end{array}$ & 0 & 1 & 2 & 3 & 4 \\
\hline 3 & Have you had painful aching in your mouth? & 0 & 1 & 2 & 3 & 4 \\
\hline 4 & $\begin{array}{l}\text { Have you found it uncomfortable to eat any foods because of problems with your } \\
\text { teeth, mouth or dentures? }\end{array}$ & 0 & 1 & 2 & 3 & 4 \\
\hline 5 & Have you been self-conscious because of your teeth, mouth or dentures? & 0 & 1 & 2 & 3 & 4 \\
\hline 6 & Have you felt tense because of problems with your teeth, mouth or dentures? & 0 & 1 & 2 & 3 & 4 \\
\hline 7 & $\begin{array}{l}\text { Has your diet been unsatisfactory because of problems with your teeth, mouth or } \\
\text { dentures? }\end{array}$ & 0 & 1 & 2 & 3 & 4 \\
\hline 8 & $\begin{array}{l}\text { Have you had to interrupt meals because of problems with your teeth, mouth or } \\
\text { dentures? }\end{array}$ & 0 & 1 & 2 & 3 & 4 \\
\hline 9 & $\begin{array}{l}\text { Have you found it difficult to relax because of problems with your teeth, mouth } \\
\text { or dentures? }\end{array}$ & 0 & 1 & 2 & 3 & 4 \\
\hline 10 & $\begin{array}{l}\text { Have you been a bit embarrassed because of problems with your teeth, mouth or } \\
\text { dentures? }\end{array}$ & 0 & 1 & 2 & 3 & 4 \\
\hline 11 & $\begin{array}{l}\text { Have you been a bit irritable with other people because of problems with your } \\
\text { teeth, mouth or dentures? }\end{array}$ & 0 & 1 & 2 & 3 & 4 \\
\hline 12 & $\begin{array}{l}\text { Have you had difficulty doing your usual jobs because of problems with your } \\
\text { teeth, mouth or dentures? }\end{array}$ & 0 & 1 & 2 & 3 & 4 \\
\hline 13 & $\begin{array}{l}\text { Have you felt that life in general was less satisfying because of problems with } \\
\text { your teeth, mouth or dentures? }\end{array}$ & 0 & 1 & 2 & 3 & 4 \\
\hline 14 & $\begin{array}{l}\text { Have you been totally unable to function because of problems with your teeth, } \\
\text { mouth or dentures? }\end{array}$ & 0 & 1 & 2 & 3 & 4 \\
\hline
\end{tabular}

Figure 21. OHIP-14 Post-Operative Day 1 


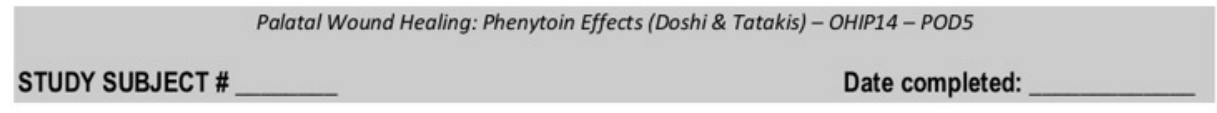

OHIP-14

Please read each statement and circle a number $0,1,2,3$ or 4 which indicates how much the statement applies to you over the past $\mathbf{4}$ days (i.e., since your last visit). There are no right or wrong answers. Do not spend too much time on any statement.

The rating scale is as follows:

0 Never

1 Hardly ever

2 Occasionally

3 Fairly often

4 Very often

\begin{tabular}{|c|c|c|c|c|c|c|}
\hline 1 & $\begin{array}{l}\text { Have you had trouble pronouncing any words because of problems with your } \\
\text { teeth, mouth or dentures? }\end{array}$ & 0 & 1 & 2 & 3 & 4 \\
\hline 2 & $\begin{array}{l}\text { Have you felt that your sense of taste has worsened because of problems with } \\
\text { your teeth, mouth or dentures? }\end{array}$ & 0 & 1 & 2 & 3 & 4 \\
\hline 3 & Have you had painful aching in your mouth? & 0 & 1 & 2 & 3 & 4 \\
\hline 4 & $\begin{array}{l}\text { Have you found it uncomfortable to eat any foods because of problems with your } \\
\text { teeth, mouth or dentures? }\end{array}$ & 0 & 1 & 2 & 3 & 4 \\
\hline 5 & Have you been self-conscious because of your teeth, mouth or dentures? & 0 & 1 & 2 & 3 & 4 \\
\hline 6 & Have you felt tense because of problems with your teeth, mouth or dentures? & 0 & 1 & 2 & 3 & 4 \\
\hline 7 & $\begin{array}{l}\text { Has your diet been unsatisfactory because of problems with your teeth, mouth or } \\
\text { dentures? }\end{array}$ & 0 & 1 & 2 & 3 & 4 \\
\hline 8 & $\begin{array}{l}\text { Have you had to interrupt meals because of problems with your teeth, mouth or } \\
\text { dentures? }\end{array}$ & 0 & 1 & 2 & 3 & 4 \\
\hline 9 & $\begin{array}{l}\text { Have you found it difficult to relax because of problems with your teeth, mouth } \\
\text { or dentures? }\end{array}$ & 0 & 1 & 2 & 3 & 4 \\
\hline 10 & $\begin{array}{l}\text { Have you been a bit embarrassed because of problems with your teeth, mouth or } \\
\text { dentures? }\end{array}$ & 0 & 1 & 2 & 3 & 4 \\
\hline 11 & $\begin{array}{l}\text { Have you been a bit irritable with other people because of problems with your } \\
\text { teeth, mouth or dentures? }\end{array}$ & 0 & 1 & 2 & 3 & 4 \\
\hline 12 & $\begin{array}{l}\text { Have you had difficulty doing your usual jobs because of problems with your } \\
\text { teeth, mouth or dentures? }\end{array}$ & 0 & 1 & 2 & 3 & 4 \\
\hline 13 & $\begin{array}{l}\text { Have you felt that life in general was less satisfying because of problems with } \\
\text { your teeth, mouth or dentures? }\end{array}$ & 0 & 1 & 2 & 3 & 4 \\
\hline 14 & $\begin{array}{l}\text { Have you been totally unable to function because of problems with your teeth, } \\
\text { mouth or dentures? }\end{array}$ & 0 & 1 & 2 & 3 & 4 \\
\hline
\end{tabular}

Figure 22. OHIP 14 


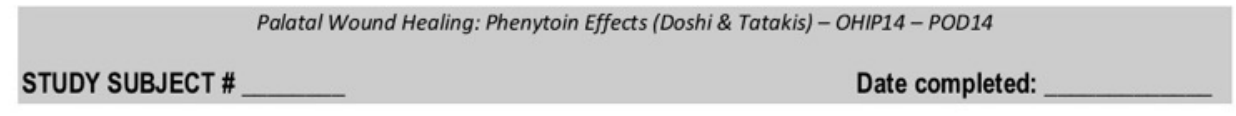

\section{OHIP-14}

Please read each statement and circle a number $0,1,2,3$ or 4 which indicates how much the statement applies to you over the past week. There are no right or wrong answers. Do not spend too much time on any statement.

The rating scale is as follows:

0 Never

1 Hardly ever

2 Occasionally

3 Fairly often

4 Very often

\begin{tabular}{|c|c|c|c|c|c|c|}
\hline 1 & $\begin{array}{l}\text { Have you had trouble pronouncing any words because of problems with your } \\
\text { teeth, mouth or dentures? }\end{array}$ & 0 & 1 & 2 & 3 & 4 \\
\hline 2 & $\begin{array}{l}\text { Have you felt that your sense of taste has worsened because of problems with } \\
\text { your teeth, mouth or dentures? }\end{array}$ & 0 & 1 & 2 & 3 & 4 \\
\hline 3 & Have you had painful aching in your mouth? & 0 & 1 & 2 & 3 & 4 \\
\hline 4 & $\begin{array}{l}\text { Have you found it uncomfortable to eat any foods because of problems with your } \\
\text { teeth, mouth or dentures? }\end{array}$ & 0 & 1 & 2 & 3 & 4 \\
\hline 5 & Have you been self-conscious because of your teeth, mouth or dentures? & 0 & 1 & 2 & 3 & 4 \\
\hline 6 & Have you felt tense because of problems with your teeth, mouth or dentures? & 0 & 1 & 2 & 3 & 4 \\
\hline 7 & $\begin{array}{l}\text { Has your diet been unsatisfactory because of problems with your teeth, mouth or } \\
\text { dentures? }\end{array}$ & 0 & 1 & 2 & 3 & 4 \\
\hline 8 & $\begin{array}{l}\text { Have you had to interrupt meals because of problems with your teeth, mouth or } \\
\text { dentures? }\end{array}$ & 0 & 1 & 2 & 3 & 4 \\
\hline 9 & $\begin{array}{l}\text { Have you found it difficult to relax because of problems with your teeth, mouth } \\
\text { or dentures? }\end{array}$ & 0 & 1 & 2 & 3 & 4 \\
\hline 10 & $\begin{array}{l}\text { Have you been a bit embarrassed because of problems with your teeth, mouth or } \\
\text { dentures? }\end{array}$ & 0 & 1 & 2 & 3 & 4 \\
\hline 11 & $\begin{array}{l}\text { Have you been a bit irritable with other people because of problems with your } \\
\text { teeth, mouth or dentures? }\end{array}$ & 0 & 1 & 2 & 3 & 4 \\
\hline 12 & $\begin{array}{l}\text { Have you had difficulty doing your usual jobs because of problems with your } \\
\text { teeth, mouth or dentures? }\end{array}$ & 0 & 1 & 2 & 3 & 4 \\
\hline 13 & $\begin{array}{l}\text { Have you felt that life in general was less satisfying because of problems with } \\
\text { your teeth, mouth or dentures? }\end{array}$ & 0 & 1 & 2 & 3 & 4 \\
\hline 14 & $\begin{array}{l}\text { Have you been totally unable to function because of problems with your teeth, } \\
\text { mouth or dentures? }\end{array}$ & 0 & 1 & 2 & 3 & 4 \\
\hline
\end{tabular}

Figure 23. OHIP-14 Post-Operative Day 14 


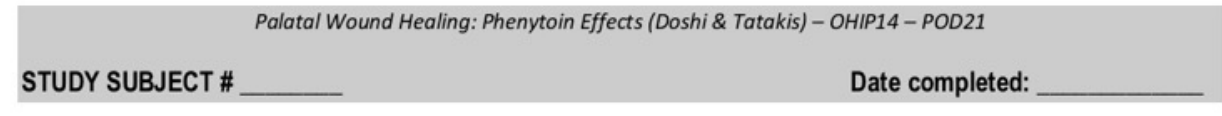

OHIP-14

Please read each statement and circle a number $0,1,2,3$ or 4 which indicates how much the statement applies to you over the past week. There are no right or wrong answers. Do not spend too much time on any statement.

The rating scale is as follows:

0 Never

1 Hardly ever

2 Occasionally

3 Fairly often

4 Very often

\begin{tabular}{|c|c|c|c|c|c|c|}
\hline 1 & $\begin{array}{l}\text { Have you had trouble pronouncing any words because of problems with your } \\
\text { teeth, mouth or dentures? }\end{array}$ & 0 & 1 & 2 & 3 & 4 \\
\hline 2 & $\begin{array}{l}\text { Have you felt that your sense of taste has worsened because of problems with } \\
\text { your teeth, mouth or dentures? }\end{array}$ & 0 & 1 & 2 & 3 & 4 \\
\hline 3 & Have you had painful aching in your mouth? & 0 & 1 & 2 & 3 & 4 \\
\hline 4 & $\begin{array}{l}\text { Have you found it uncomfortable to eat any foods because of problems with your } \\
\text { teeth, mouth or dentures? }\end{array}$ & 0 & 1 & 2 & 3 & 4 \\
\hline 5 & Have you been self-conscious because of your teeth, mouth or dentures? & 0 & 1 & 2 & 3 & 4 \\
\hline 6 & Have you felt tense because of problems with your teeth, mouth or dentures? & 0 & 1 & 2 & 3 & 4 \\
\hline 7 & $\begin{array}{l}\text { Has your diet been unsatisfactory because of problems with your teeth, mouth or } \\
\text { dentures? }\end{array}$ & 0 & 1 & 2 & 3 & 4 \\
\hline 8 & $\begin{array}{l}\text { Have you had to interrupt meals because of problems with your teeth, mouth or } \\
\text { dentures? }\end{array}$ & 0 & 1 & 2 & 3 & 4 \\
\hline 9 & $\begin{array}{l}\text { Have you found it difficult to relax because of problems with your teeth, mouth } \\
\text { or dentures? }\end{array}$ & 0 & 1 & 2 & 3 & 4 \\
\hline 10 & $\begin{array}{l}\text { Have you been a bit embarrassed because of problems with your teeth, mouth or } \\
\text { dentures? }\end{array}$ & 0 & 1 & 2 & 3 & 4 \\
\hline 11 & $\begin{array}{l}\text { Have you been a bit irritable with other people because of problems with your } \\
\text { teeth, mouth or dentures? }\end{array}$ & 0 & 1 & 2 & 3 & 4 \\
\hline 12 & $\begin{array}{l}\text { Have you had difficulty doing your usual jobs because of problems with your } \\
\text { teeth, mouth or dentures? }\end{array}$ & 0 & 1 & 2 & 3 & 4 \\
\hline 13 & $\begin{array}{l}\text { Have you felt that life in general was less satisfying because of problems with } \\
\text { your teeth, mouth or dentures? }\end{array}$ & 0 & 1 & 2 & 3 & 4 \\
\hline 14 & $\begin{array}{l}\text { Have you been totally unable to function because of problems with your teeth, } \\
\text { mouth or dentures? }\end{array}$ & 0 & 1 & 2 & 3 & 4 \\
\hline
\end{tabular}

Figure 24. OHIP-14 Post-Operative Day 21 


\section{Chapter 3. Data Management and Statistical Analysis}

For the proposed study the sample size calculations were based on clinical healing outcomes data from published studies with similar size (6 $\mathrm{mm}$ diameter) defects (Thoma et al., 2012) $)^{5}$. Sample size calculations indicated that a paired-samples study with 20 participants would have $80 \%$ power and 5\% significance level (two-sided) to detect an expected effect size of 0.7 between pairs.

Digital photographs of the sites taken at days 5, 14 and 21 were analysed using ImageJ software (NIH, Bethesda, MD, USA). Wound area was calculated, for each visit, as a percentage of the total area of the original wound ${ }^{49}\left(28.26 \mathrm{~mm}^{2}\right)$. For day 5 , the wound area was measured by tracing the periphery of the healing wound. For days 14 and 21 , only the immature areas of the wound were measured by using standardized color and brightness threshold levels (Figure 23).

The histological specimens of 10 randomly chosen subjects ( 5 from each group) were recorded by digital camera at $4 \mathrm{x}$ magnification. Each specimen was then analysed using ImageJ software (NIH, Bethesda, MD, USA). Length of the wound (L) was measured as the distance between the original incisions that could be traced histologically in each specimen. Superficial distance (S) was measured as the distance between the two proliferating epithelium edges ${ }^{50}$. Using these two parameters, Superficial Contraction Index (SCI) was calculated for each specimen as (L - S) / L. (Figure 24) 
The clinical photo analysis and the histological measurements were done by a single examiner. To determine the reliability of the examiner, wound area measurements for 7 randomly selected clinical photographs and SCI measurements for 6 randomly selected histological samples was carried out at 3 different time points, each $>24 \mathrm{hrs}$ apart. From this data, the average coefficient of variation and the Intraclass Correlation Coefficients (ICC) were calculated for both set of measurements. For the clinical photo analysis, the average coefficient of variation was $7 \%$, but the ICC was in an excellent range (ICC $>0.9$ ). For the histological analysis, average coefficient of variation for each measure (L, S, ratio) was $<2.2 \%$ and the $\mathrm{ICC}>0.9$.

Experimental data collected from questionnaires, clinical measurements, and imaging software (ImageJ) analysis was organized onto a spreadsheet format. Descriptive data were analysed using frequency distributions (numbers and percentages), measures of central tendency (means), and measures of dispersion (standard deviation).

Analysis of patient reported pain scores, clinical healing scores, OHIP-14 scores and analgesics intake was performed by using the generalized linear mixed-effect model (GLMM). Generalized logistic model was used to fit the granulation tissue and pain on palpation components of the Healing Score Index. Analysis of relative pain data was done using permutation test for overall comparison and McNemar test for comparisons at each time point. To compare analgesics intake between groups at each time point, Wilcoxon rank sum test was used.

Statistical significance was set at alpha $=0.05$. 


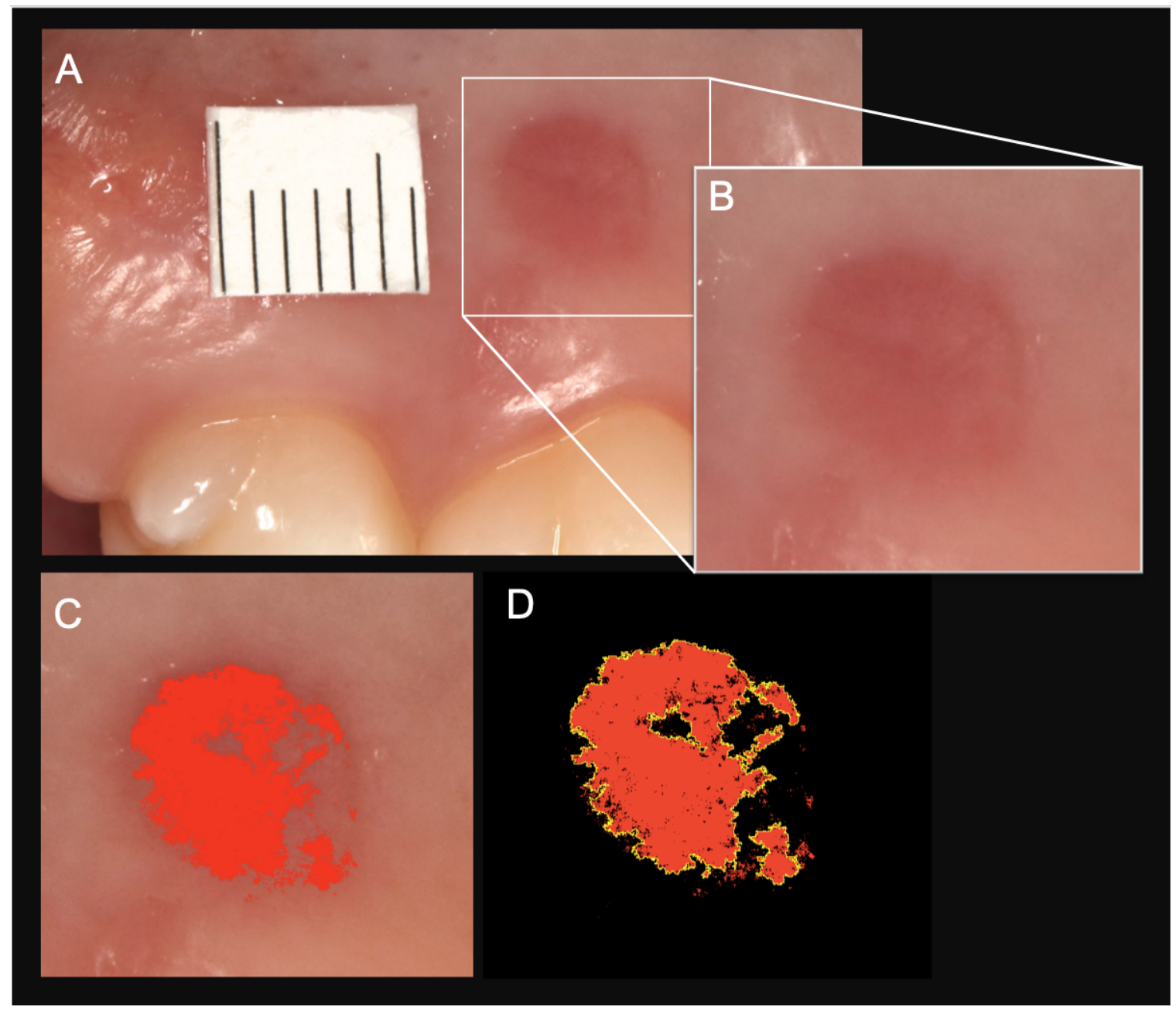

Figure 25. Imaging software analysis. Sterile paper scale next to a Day 14 posterior wound for calibration (A), Same wound zoomed-in (B), Immature wound areas selected and measured by adjusting color threshold $(\mathrm{C}$ and $\mathrm{D})$ 


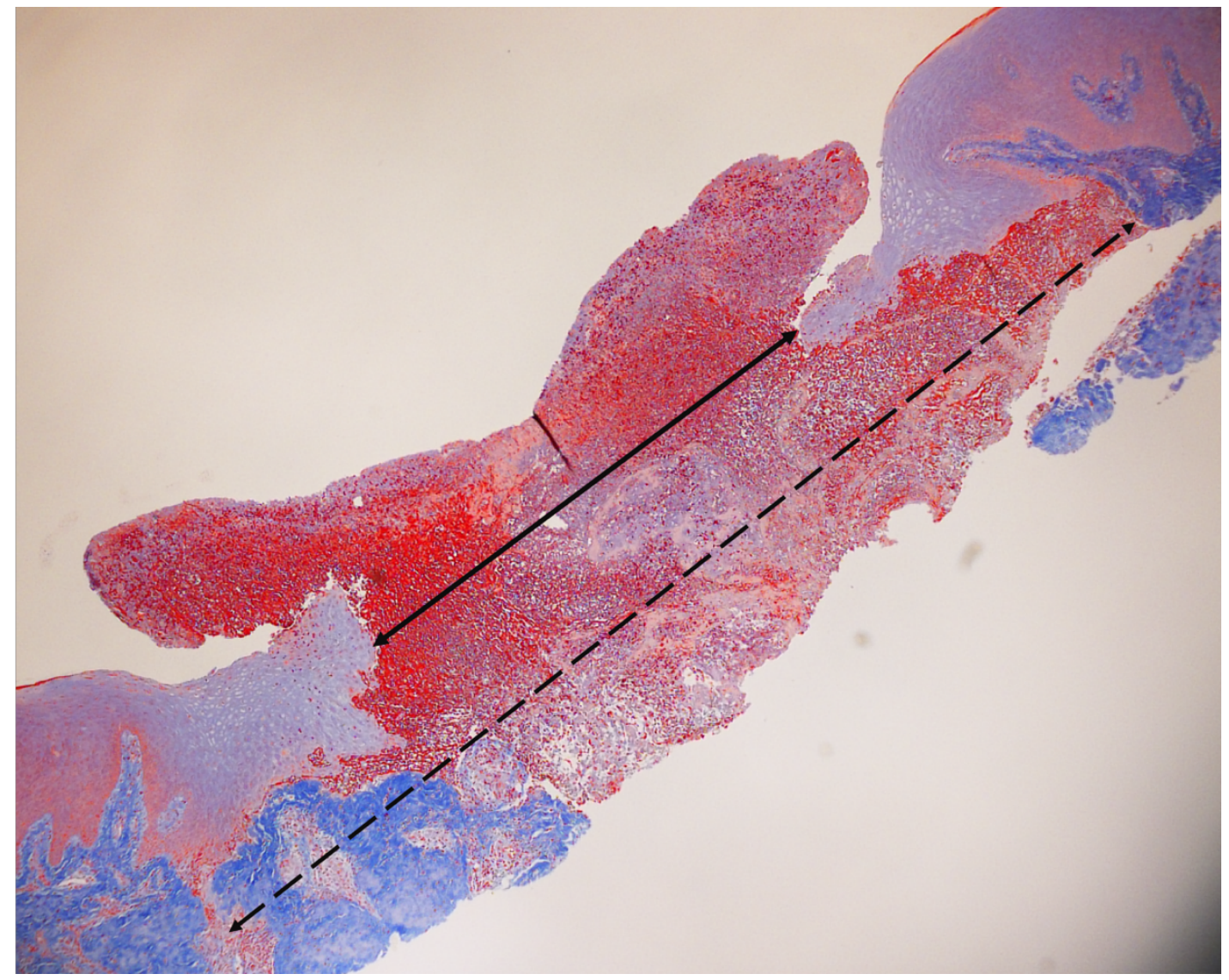

Figure 26. Histomorphological measurements. Superficial contraction (S) measured as indicated by solid arrow and original wound length (L) measured as indicated by dashed arrow. 


\section{Chapter 4. Results}

Twenty subjects were recruited for the study. All 20 subjects (16 males and 4 females; aged 25.8 \pm 2.1 years; range: 23 -31years) complied with and completed the study protocol. The average exhaled air carbon monoxide level of the recruited subjects was 3 ppm (range 1-5 ppm). Gender distribution was equal between the two biopsy groups with 8 males and 2 females in each group. All surgical procedures were successfully and uneventfully completed.

No adverse events were observed on phenytoin side whereas one control side exhibited liver clot formation at post-operative Day 1 and another control side exhibited herpetic ulcerations at post-operative Day 5.

\section{$\underline{\text { Clinical outcomes }}$}

\section{Healing Score Index}

The Healing Score Index (HSI = total of all 7 healing score index components), as well as the individual scores for each component, were compared between the control and PHT sides (See figures 28-33). The HSI, as expected, improved (higher score) with each subsequent follow-up visit on both sides, with the Day 14 and Day 21 HSI being significantly higher $(\mathrm{p}<0.0001)$ than the Day 1 HSI. The average HSI for the PHT side was consistently higher (suggestive of better healing) at every follow-up visit. This 
difference in the HSI between the control and PHT sites was statistically significant at Day $5(\mathrm{p}=0.037)$ and Day $21(\mathrm{p}=0.003)$ (Figure 28).

As for each individual component of the HSI, no wounds exhibited suppuration at any time. Overall, PHT treated sites were more likely to not exhibit swelling $(O R=9.35$; $\mathrm{p}=0.009)$ (Figure 31$)$ and to not experience pain on palpation $(\mathrm{OR}=6.278 ; \mathrm{p}=0.007)$ (Figure 32). PHT also had a significant and time-dependent effect on granulation tissue appearance $(\mathrm{p}=0.004)$ (Figure 33).

Number of control sites that had pain on palpation were significantly lower at Day $5(\mathrm{p}=0.02)$ and at Day $14(\mathrm{p}=0.047)$ compared to Day 1 control sites (Figure 29). Pain on palpation on PHT sites was not significantly different over time (Figures 29 and 30). For sites with presence of granulation tissue, there was a significant increase from Day 1 to Day 5 for control sites $(\mathrm{p}=0.003)$ and a significant decrease in number of sites from Day 1 to Day 14 for both PHT $(\mathrm{p}<0.0001)$ and control sites $(\mathrm{p}=0.004)$. No sites exhibited granulation tissue, swelling or pain on palpation at Day 21. Peroxide test:

There was no difference between control and PHT sides at day 14 and 21 in complete wound epithelialization (CWE) as recorded by $\mathrm{H}_{2} \mathrm{O}_{2}$ test. CWE was observed at $70 \%$ of sites on day 14 and $95 \%$ of the sites at day 21 , for both control and PHT. Wound closure analysis:

Wound area measurements were completed for each of the 20 participants. However, for post-operative Day 5, the participant that had developed a liver clot on the control side at day 1 , now exhibited a thrombus formation at the wounds which hampered the wound measurements and hence, was excluded from the analysis. For the other 19 
participants, the average Day 5 wound area, measured as percentage of the original wound area, was $77.6 \pm 4.7 \%$ and $79.9 \pm 4.1 \%$ for control and PHT wounds, respectively. At post-operative Day 14, the average wound areas were $36.7 \pm 4.7 \%$ and $40.6 \pm 5.1 \%$ for control and PHT sites, respectively. At Day 21, the corresponding values for average wound areas were $18.2 \pm 2.9 \%$ and $20.7 \pm 2.8 \%$ (Figure 34 ). Time a had significant effect on wound closure $(\mathrm{p}=0.000)$ but the difference between with control and PHT sites failed to reach statistical significance at any time point $(\mathrm{p}=0.684)$.

\section{Patient centered outcomes}

Custom Questionnaires:

At Day 1, 35\% of the participants reported equal pain on both sides, $30 \%$ reported more pain on the control side whereas none of participants reported more pain on the PHT side. This difference between control and PHT sites was statistically significant $(\mathrm{p}=0.014)$ (Figure 35). However, overall, PHT's effect on patient's reported relative pain failed to reach statistical significance $(\mathrm{p}=0.265)$.

The mean \pm standard deviation (SD) VAS (pain) scores for all participants at Day 1 was $1.9 \pm 1.83$ (range 0-5) and 1.45 \pm 1.82 (range 0-5) for the control and PHT sides, respectively. The mean VAS scores for the Day 5 post-operative visit for 19 of the 20 participants was $1.58 \pm 1.87$ (range $0-8$ ) and $1.42 \pm 1.84$ (range 0-7) for the control and PHT sides, respectively. 1 participant was excluded from the VAS analysis as the reported pain scores were related to TMJ discomfort experienced from bruxing on the clasp of the post-operative stent and unrelated to the wounds. The Day 14 mean VAS scores for all participants were $0.95 \pm 1.43$ (range $0-5$ ) and $0.95 \pm 1.39$ (range $0-5$ ) for the 
control and PHT sides, respectively. All subjects reported no pain for both control and PHT sides at post-operative day 21 (Figure 36). Although the mean VAS scores were consistently lower on PHT sites than the control sites, the difference was not statistically significant $(\mathrm{p}=0.533)$. Consistent with the clinical healing scores and wound closure analysis, time had a significant effect on patient reported pain outcomes $(p<0.001)$. All participants described the pain at all time points in the range of 0 to 2 , that is, no pain to tolerable pain preventing some activities.

Group 1 participants, on average, took more analgesics on Day 0 and Day 1 , consistent with their wounding and biopsy procedure timing. Similarly, Group 2 participants, on average, took more analgesics on Day 5, also consistent with the timing of their biopsy procedure. Only one participant (Group 2) reported taking analgesics up to Day 14 (Figure 37 ). The total analgesic consumption was not significantly different over time $(\mathrm{p}=0.904)$ but was significantly different between the two biopsy groups $(p=0.00001)$, with Group 1 having a higher total analgesic consumption than Group 2. However, at Day 5, Group 2 had a significant higher number of Acetaminophen consumption than Group $1(\mathrm{p}=0.035)$.

Oral Health Impact Profile-14

There was no statistically significant difference in OHIP-14 scores between the two biopsy groups at any time point $(\mathrm{p}=0.337)$. (Figure 39$)$. Time had a significant effect on the OHIP-14 score $(p=0.000)$, with an average decrease in the total score by 0.46 each day. The mean baseline OHIP-14 score was $1.3 \pm 0.5$ that peaked to $9.5 \pm 8.0$ at Day 1 for both groups and returned to baseline levels at Day 21. The OHIP-14 scores were 
significantly higher than baseline scores at Day $1(\mathrm{p}=0.000)$, Day $5(\mathrm{p}=0.000)$ and Day $14(\mathrm{p}=0.034)$.

Histological outcomes

Histomorphological measurements were completed for 9 of the 10 participants ( 5 Group 1 and 4 Group 2) because one (group 2) histological specimen had lost one of the two intact epithelial wound edges which prevented accurate determination of superficial wound length for wound contraction measurements. At Day 1, the mean superficial contraction index $(\mathrm{SCI})$ was $0.19 \pm 0.04$ and $0.15 \pm 0.06$ for control and PHT sides respectively. At Day 5, the mean SCI was $0.63 \pm 0.05$ and $0.50 \pm 0.13$ for control and PHT sites respectively (Figure 42). This difference in SCI between Group 1 biopsies and Group 2 biopsies was statistically significant $(p<0.001)$ suggestive of great wound contraction at Day 5. There was no statistically significant $(\mathrm{p}=0.853)$ difference in wound contraction between control and PHT at Day 1 or at Day 5 . 


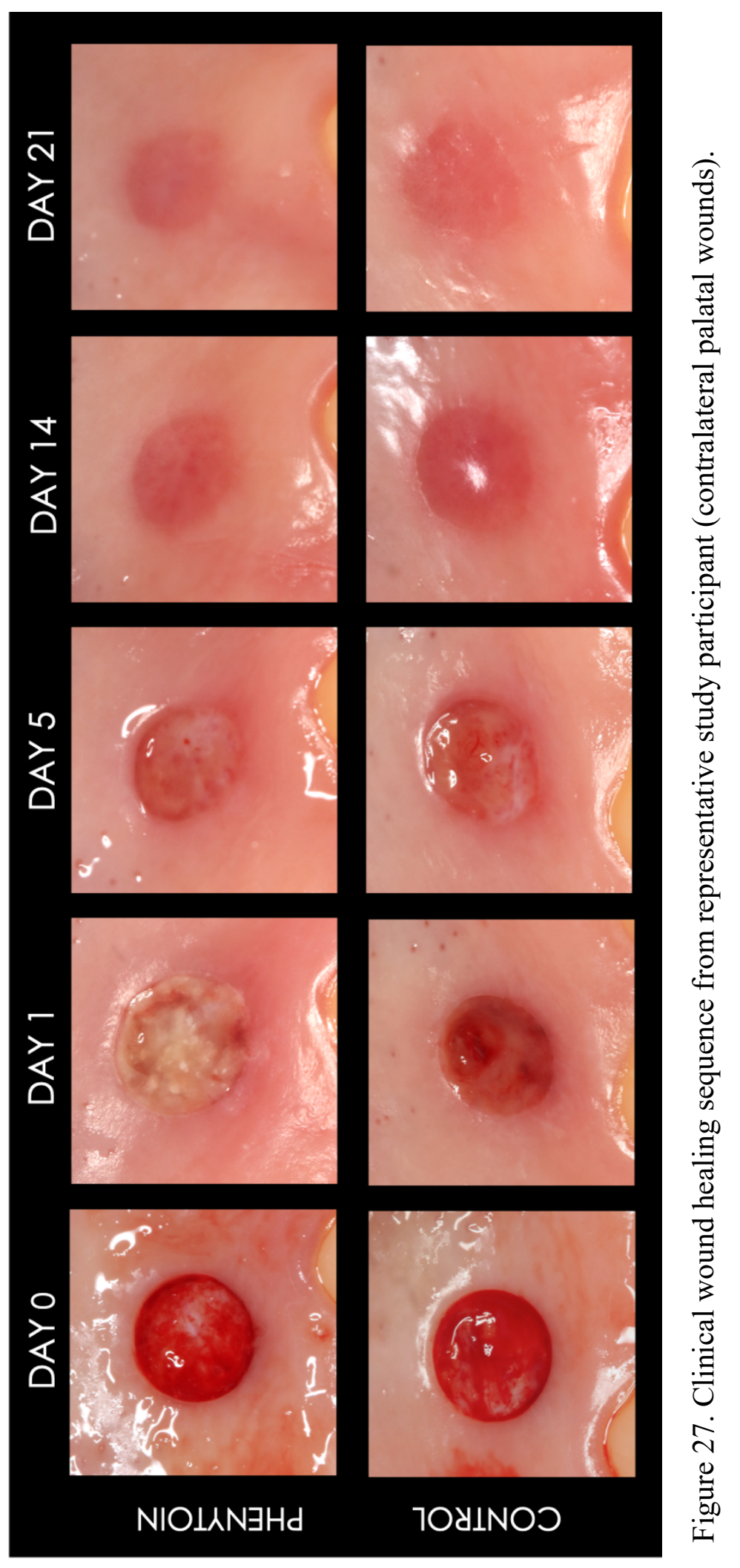




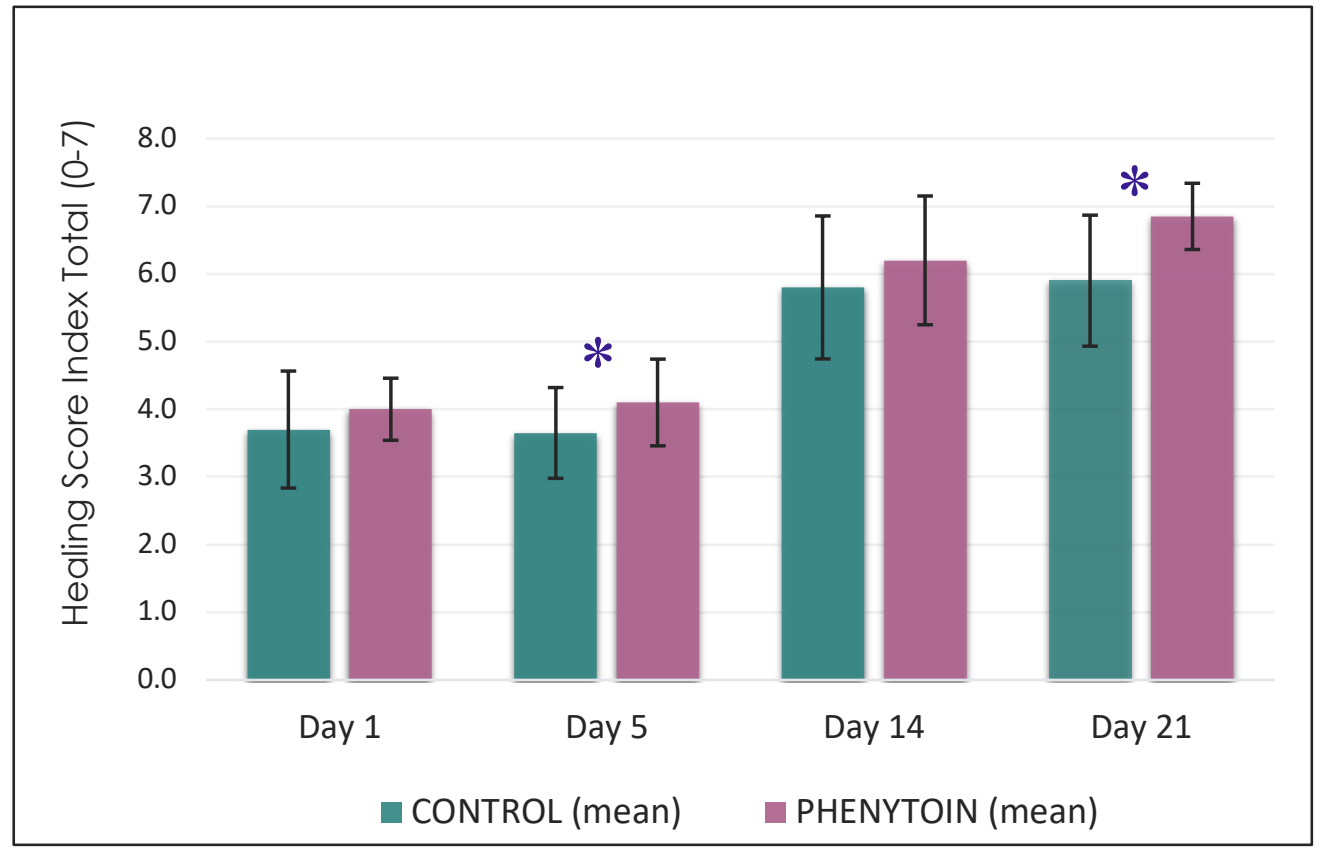

Figure 28. Healing Score Index (HSI)

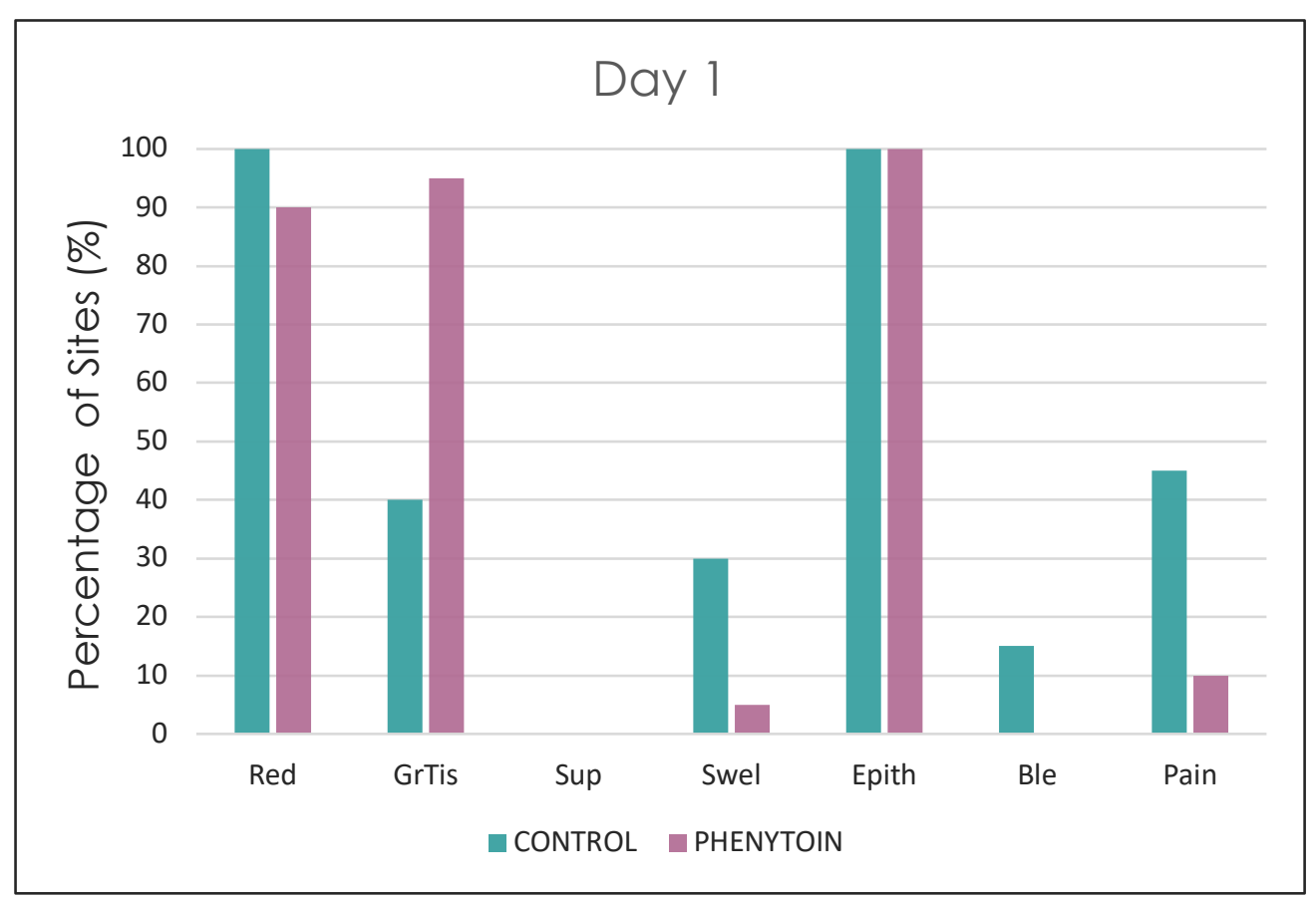

Figure 29. Healing Score Index - Individual components at Day 1 


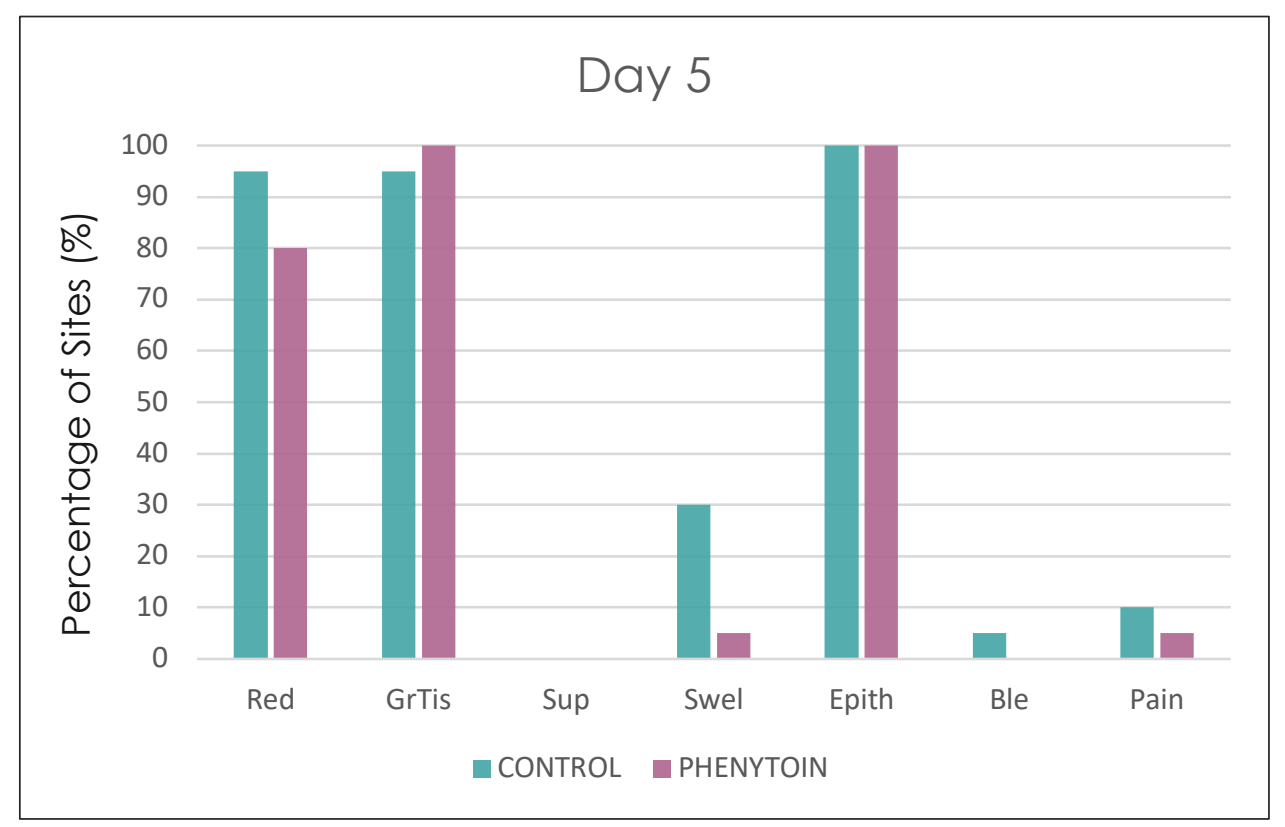

Figure 30. Healing Score Index - Individual components at Day 5

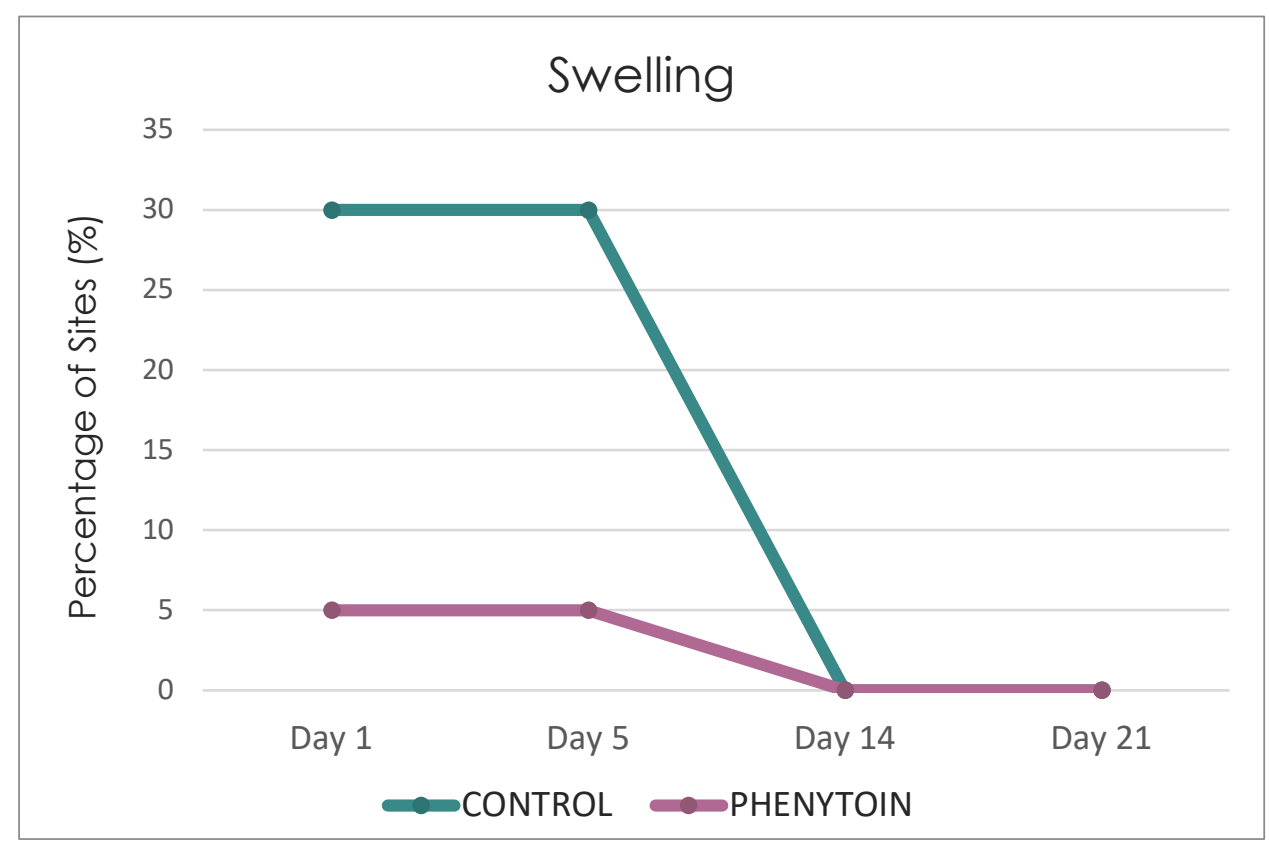

Figure 31. Presence of Swelling - Phenytoin vs Control sites 


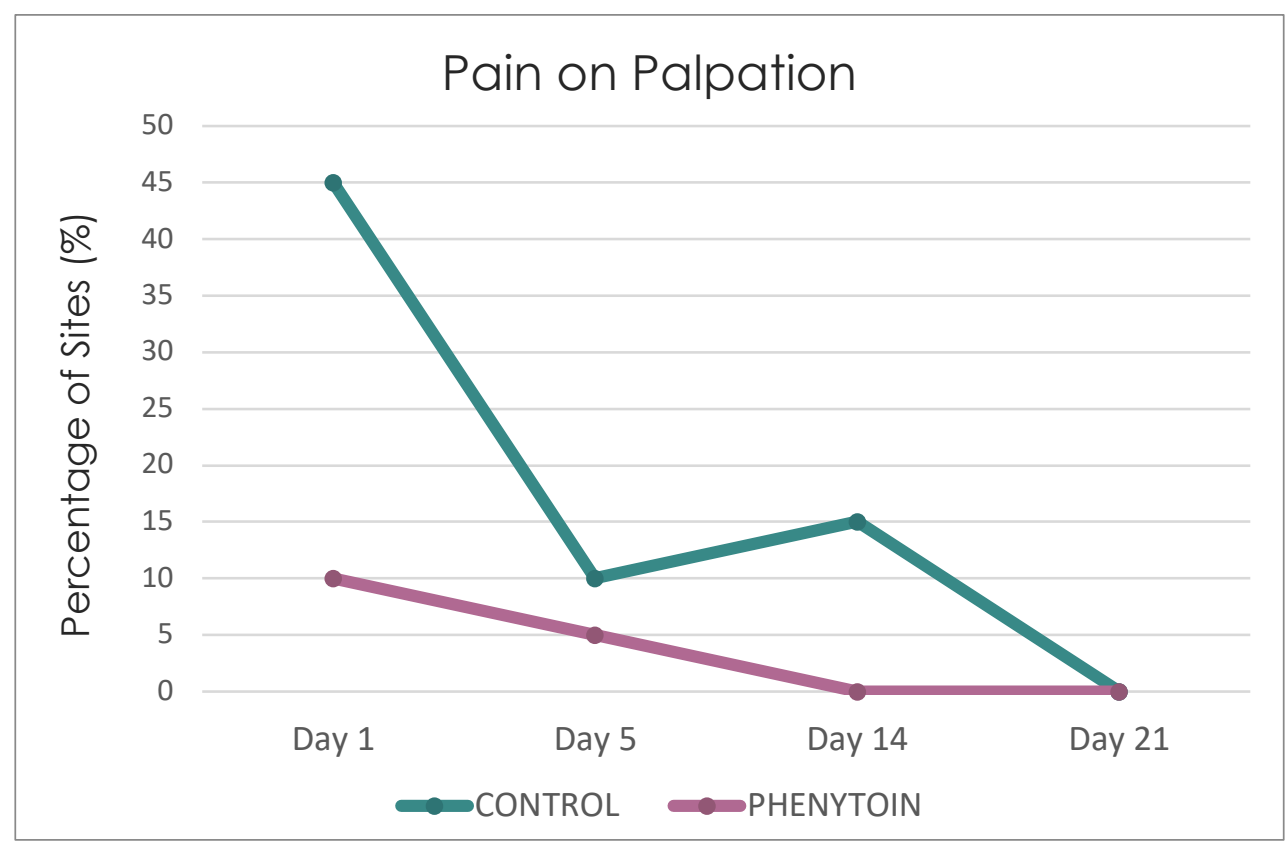

Figure 32. Presence of Pain on Palpation - Phenytoin vs Control sites

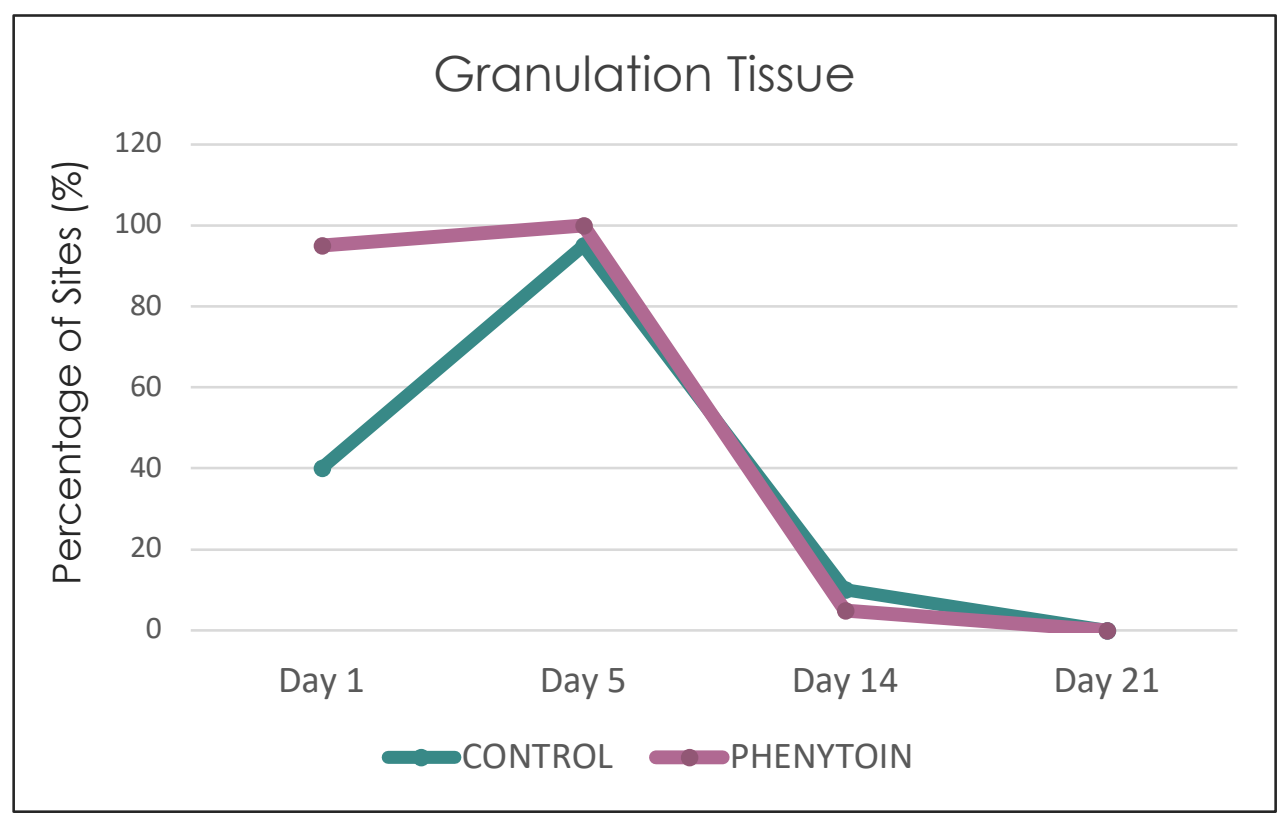

Figure 33. Presence of Granulation Tissue - Phenytoin vs Control sites 


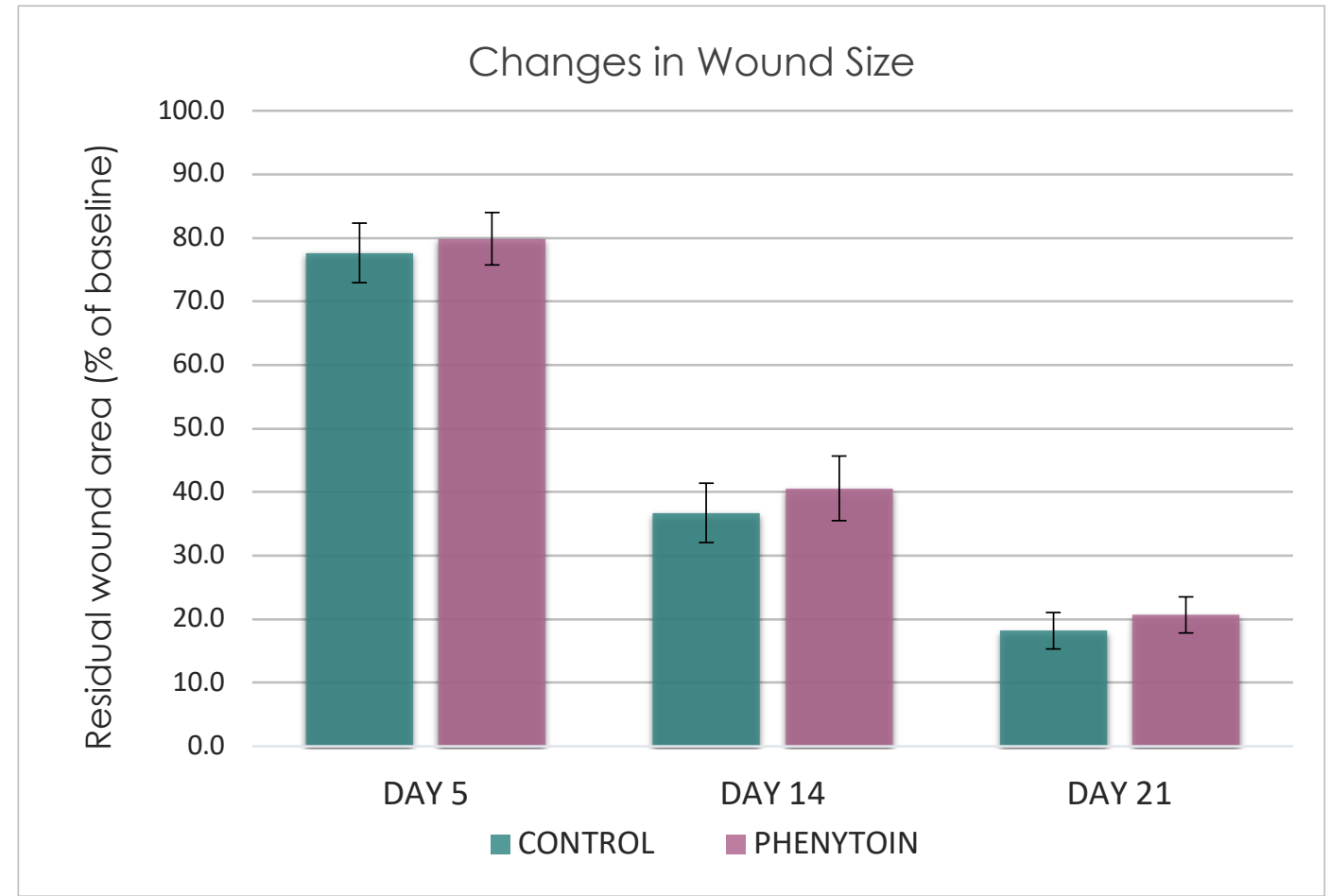

Figure 34. Changes in wound area measured as percentage of original standardized wound area $\left(28.26 \mathrm{~mm}^{2}\right)$ 


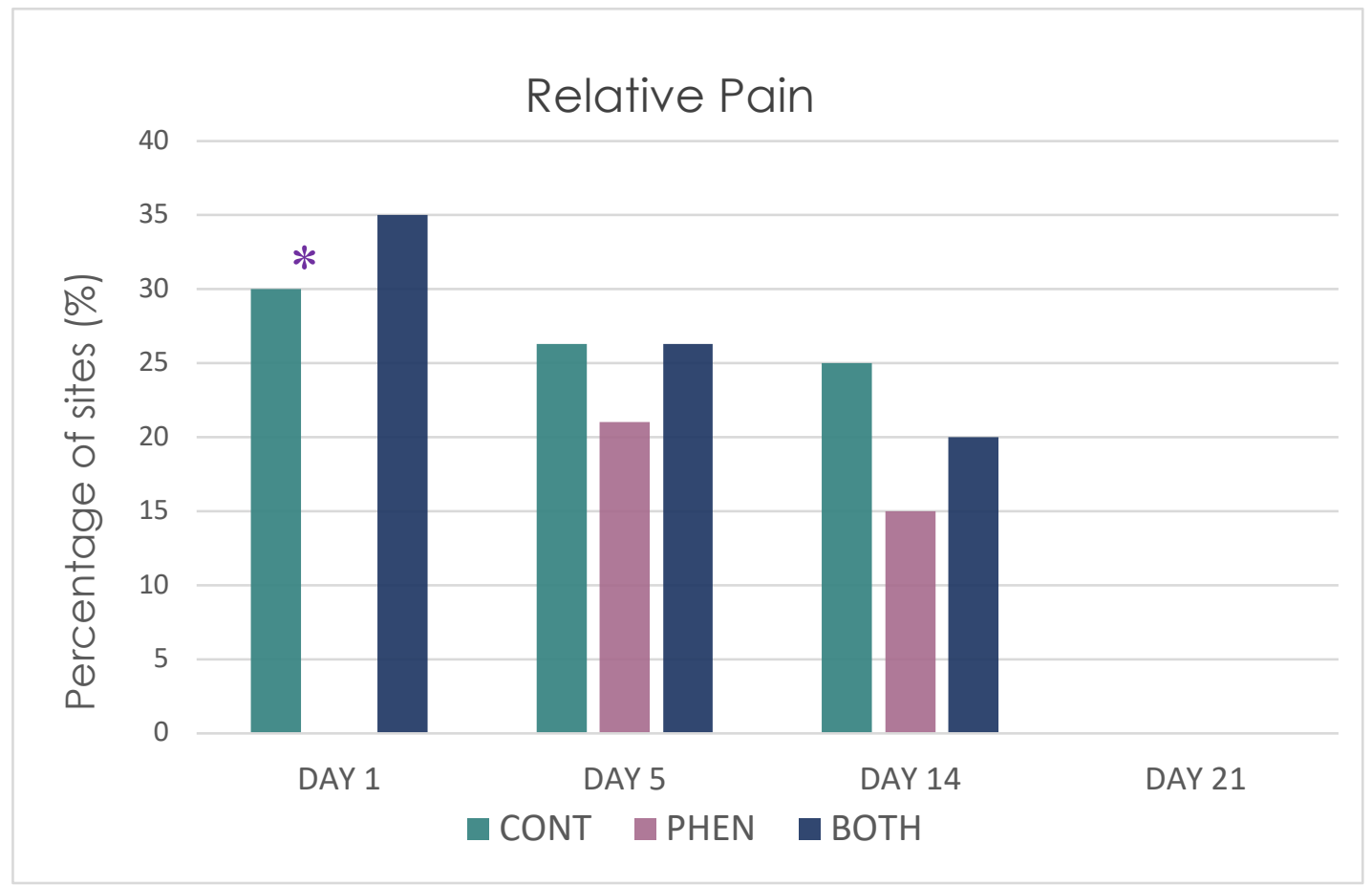

Figure 35. Patient reported relative pain at each follow-up visit. 


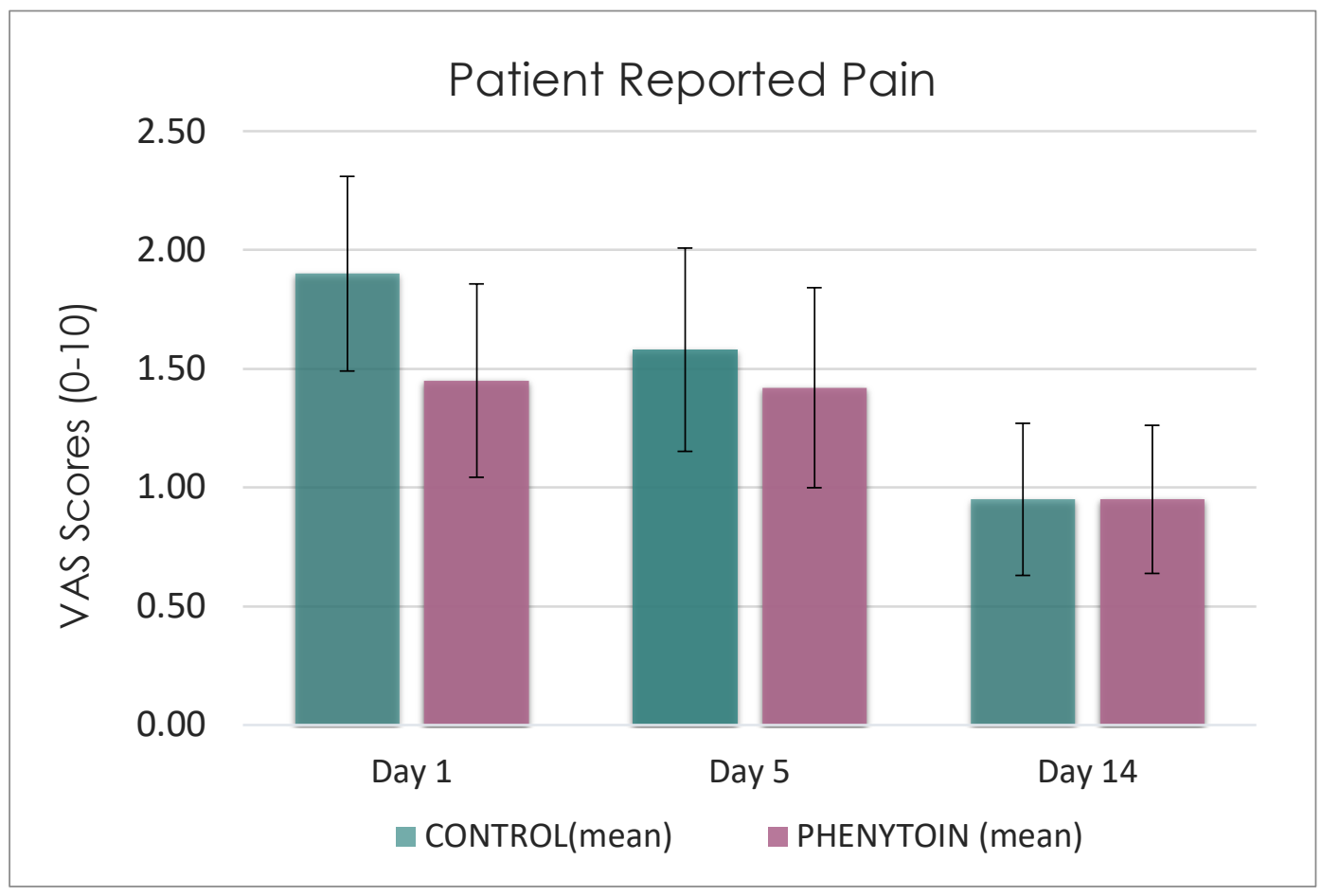

Figure 36. Pain Scores (VAS Scores) at Post-operative day 1, 5, and 14 


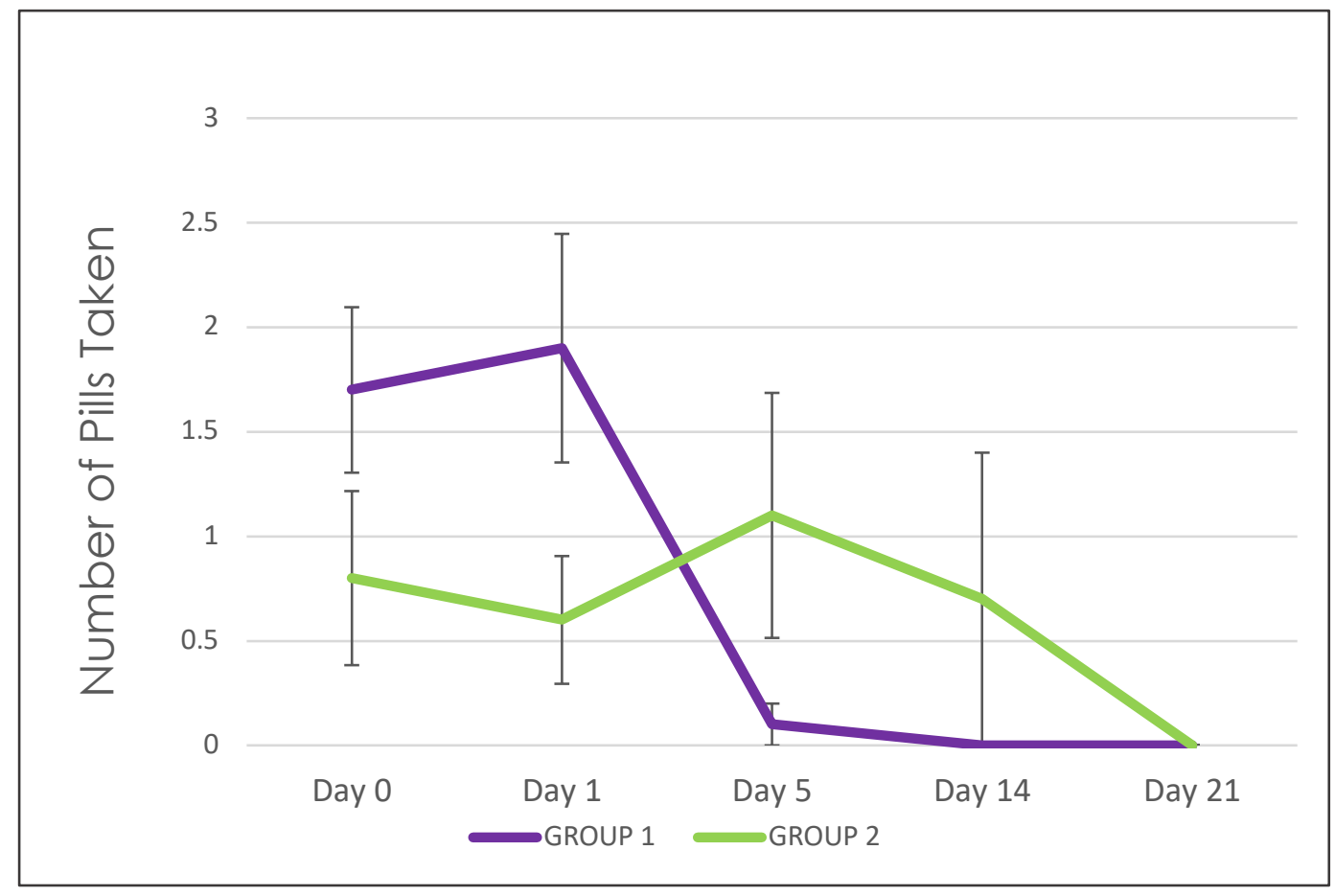

Figure 37. Analgesic consumption (mean) - Group 1 vs Group 2 


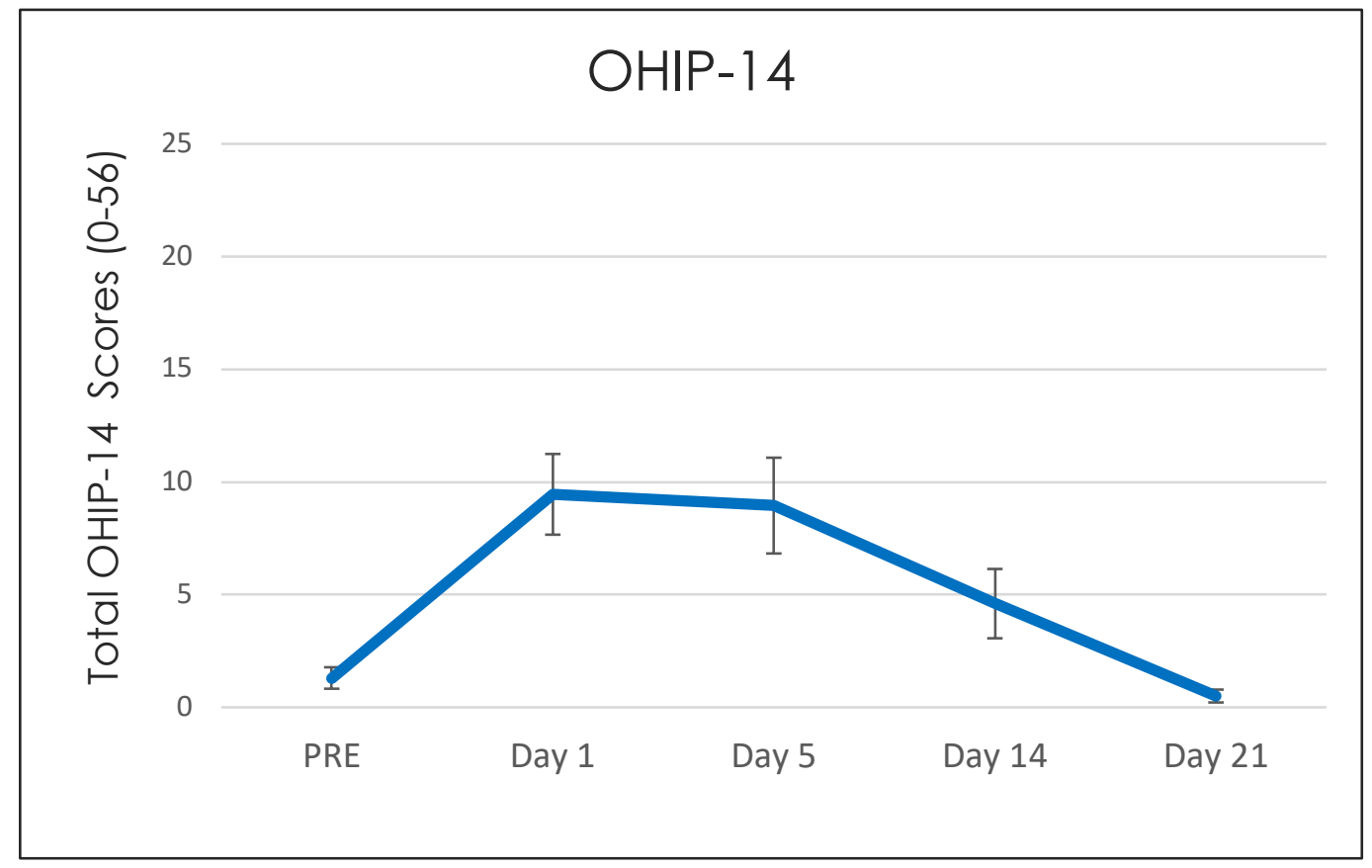

Figure 38. OHIP-14 Scores

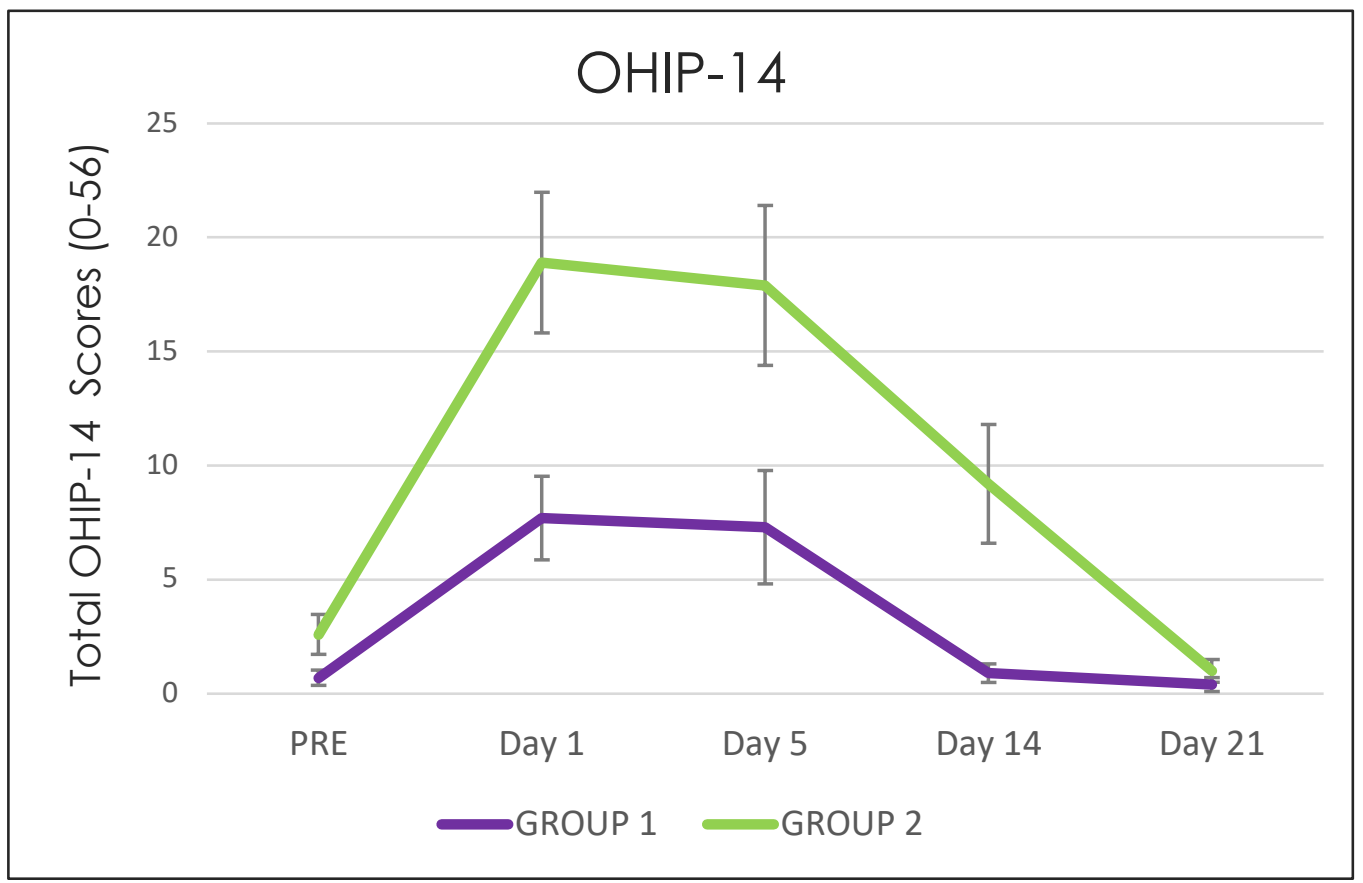

Figure 39. OHIP-14 Scores - Group 1 vs Group 2 


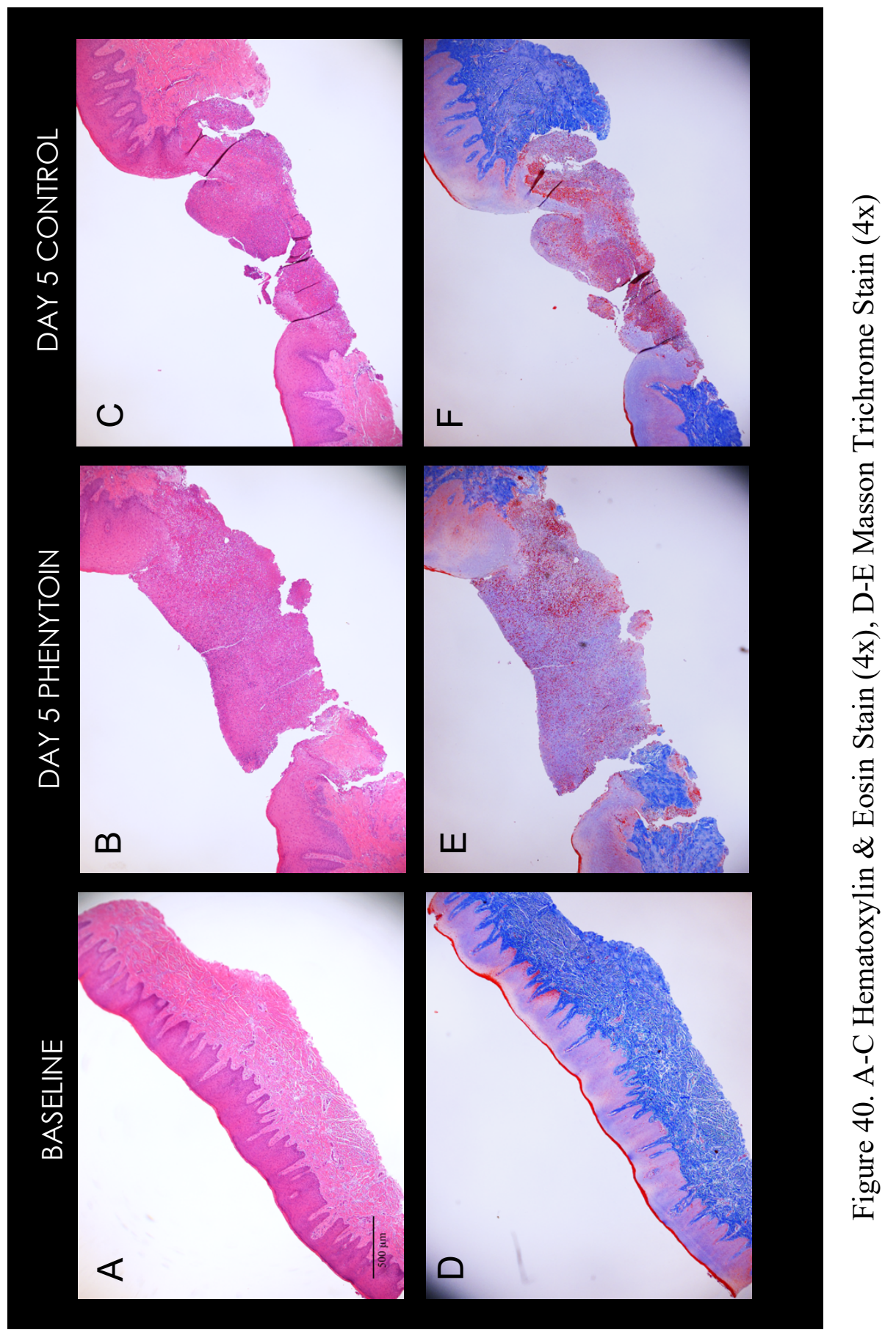




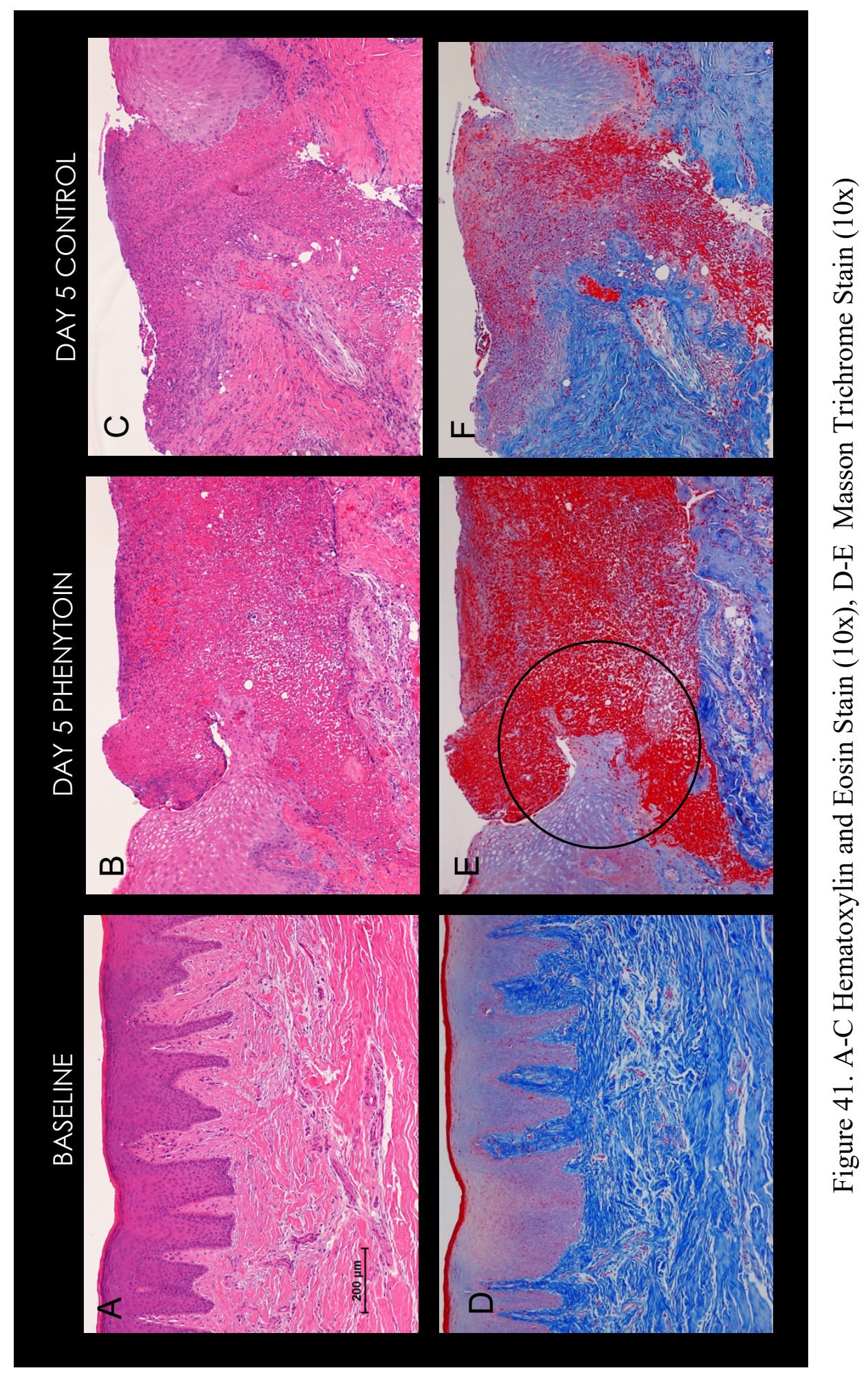




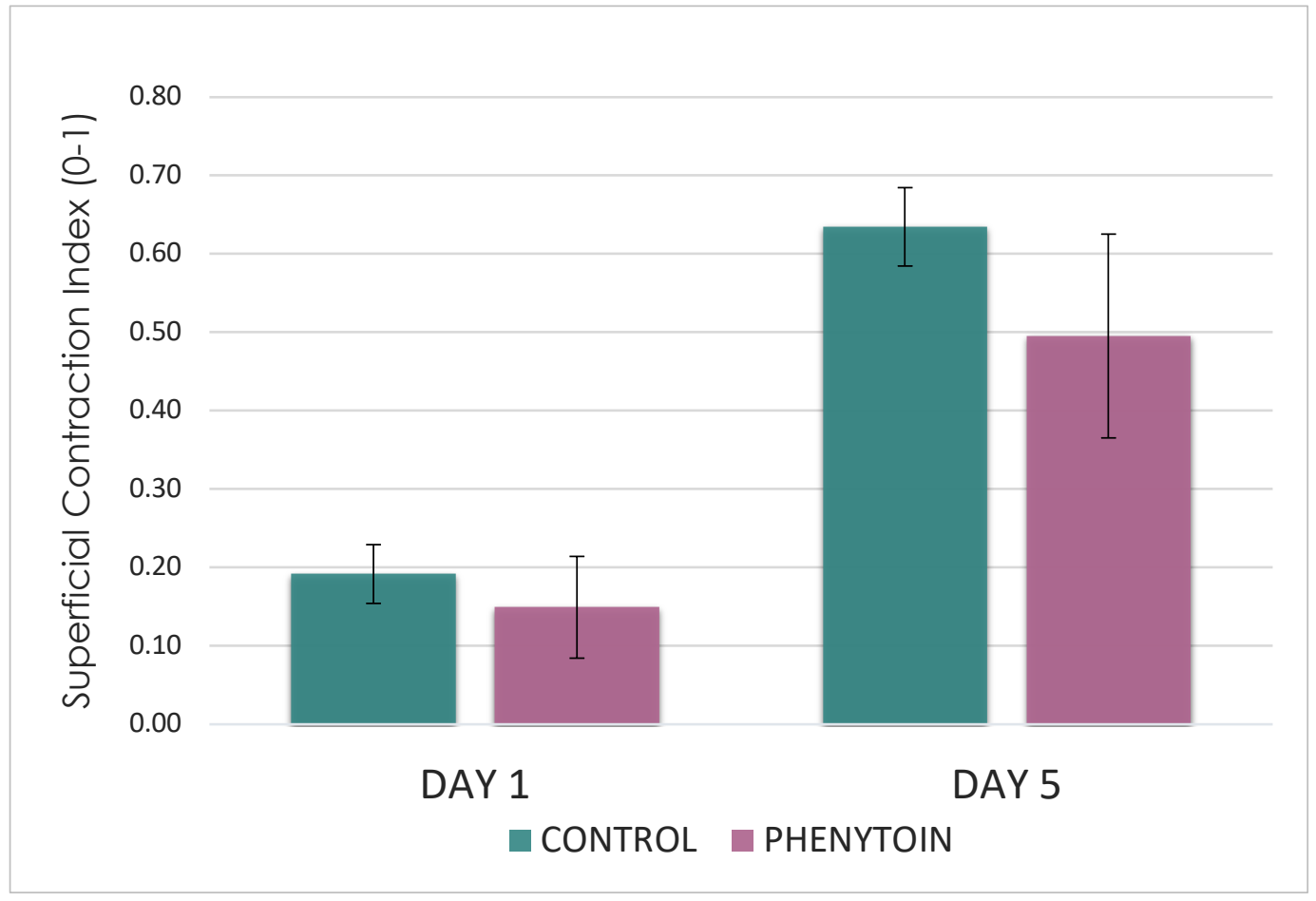

Figure 42. Histological outcomes. Superficial Contraction Index - Phenytoin vs Control at Day 1 and Day 5 


\section{Chapter 5. Discussion}

This study aimed to investigate the clinical effects of a topical PHT formulation on healing of experimental palatal wounds that model FGG donor sites and to gather new information on post-harvesting palatal wound morbidity. Clinically, the results indicated that topical PHT application improved objective clinical outcomes. To the best of our knowledge, this study is the first one to report on the clinical and histological effects of topical PHT as a palatal wound treatment regimen.

The incidence rate of PHT induced gingival overgrowth ranges from 3 to $93 \%$, with about $50 \%$ of patients that are on long-term oral PHT treatment developing gingival enlargement ${ }^{51}$. Previous studies have indicated that the selective incidence of PHT induced gingival enlargement is a result of individual susceptibility to the action of PHT in gingiva and not to the amount of drug or local factors ${ }^{52}$. It has been suggested that it is the presence or absence of PHT-sensitive population of fibroblasts within an individual that determines each individuals susceptibility ${ }^{53}$. However, to what extent does this genetically determined host susceptibility affect individual's clinical and molecular response to topical PHT application still remains under speculation. The planned gene expression analysis could help provide further insights into the molecular effects of PHT to palatal gingiva.

In this study, the healing score index totals for each follow-up visit were in favor of PHT treated sites as well as three individual components: swelling, granulation tissue 
presence and pain on palpation. PHT treated sites were less likely to exhibit swelling $(\mathrm{p}=0.009)$. This effect on swelling is consistent with the results of other studies that have suggested the use of PHT as topical wound healing treatment because of its particular benefits on reducing inflammation and edema. ${ }^{18,20,36}$ A possible explanation for phenytoin's effect on reducing edema and swelling that has been discussed in other studies ${ }^{17}$ is the anti-inflammatory property of phenytoin. Studies on diabetic foot ulcers and other infected wounds have also attributed this benefit to its antimicrobial properties. The reduction in bacterial load within the wound would results in a reduction in wound exudate and consequently a reduction in swelling. Microbiological analysis of wounds was not included in the present study but should certainly be a consideration for future phenytoin studies of this nature, especially in smokers and diabetics.

The mean pain (VAS) scores for PHT and control sites were 1.45 and 1.9 respectively, at Day 1 and 1.42 and 1.58 respectively, at Day 5. These scores are lower than those reported for FGG donor sites at postoperative day $3 .^{3}$ The lower severity of pain in this study may be attributed to the smaller wound size compared to routine FGG harvest. However, despite the overall lower severity and incidence of pain, $30 \%$ of the participants reported more pain on the control side at Day 1 whereas none reported more pain on the phenytoin side. PHT sites were also more likely to not experience pain on palpation; this difference was statistically significant $(\mathrm{OR}=6.278 ; \mathrm{p}=0.007)$. Therefore, despite being applied to a wound quite smaller than a routine FGG donor site, PHT was still shown to provide an objective benefit with respect to elicited pain. This finding is consistent with other studies in the literature that have reported local analgesic effect of 
phenytoin $^{18,19}$, explained by the membrane-stabilizing actions of PHT and selective depression of repetitive neuronal activities.

Additionally, PHT had a time-dependent effect on granulation tissue appearance $(p=0.004)$. At day 1 , granulation tissue was present at $95 \%$ of the PHT sites compared to $40 \%$ of the control sites. This clinical finding was also consistent histologically (data not shown). Although this was not included in the analysis, histologically more granulation tissue was observed on the specimens from PHT side than the control side. This earlier appearance of healthy granulation tissue on sites treated with PHT is also consistent with other studies ${ }^{24,27,28}$ in the literature. The potential mechanisms by which PHT affects granulation tissue formation include enhanced fibroblast proliferation, increased collagen content and maturation, and decreased collagenase activity ${ }^{24}$.

Digital analysis of the clinical photographs of wounds showed a tendency for the wounds on the control side to have slightly accelerated healing than the PHT treated side with the immature wound areas consistently smaller on the control sides than the PHT side for both days 14 and 21 . However, there was no difference in the incidence of complete wound epithelization (CWE), at days 14 and 21, between PHT and control sites with regards to clinical assessments (HSI and peroxide test). This lack of difference in CWE may be related to the study timing of CWE assessment and/or the smaller wound size. Most studies that have reported accelerated wound healing with topical application of PHT have been on chronic skin wounds with large surface areas (range $12-400 \mathrm{~cm}^{2}$ ). In addition, most other studies that used topical PHT treatments typically repeated the PHT application daily over the course of each study; in the present study topical PHT application was repeated only twice (Days 1 and 5). 
Histologically, superficial contraction index was higher for control sites than PHT sites at both Day 1 and Day 5. PHT treated sites appeared to have reduced wound contraction and epithelial proliferation compared to controls, which was more apparent on Day 5 biopsies. Reports in literature are contradictory with regards to the influence of PHT on wound contractions ${ }^{54}$. Phenytoin has been shown to dose-dependently reduce wound contraction when applied as a powder to full-thickness porcine wounds ${ }^{55}$. However, this negative effect did not impair healing of the wounds as PHT appeared to increase matrix production to compensate for the reduced contraction, which is consistent with our histological findings. Since biopsy samples of only 9 of 20 participants were analysed histologically, conclusions cannot be made at this point. However, there appeared to be a definite trend for PHT treated wounds having reduced contraction but more granulation tissue.

The present study is not without limitations. As with any split-mouth study design, there is always the risk of 'carry-across' effect due to lack of a natural barrier. In an active-placebo clinical trial such as this one, the treatment effect can be seriously underestimated because of this carry across effect. ${ }^{56}$ Efforts were made to minimize this effect by a) first applying the control medication to the control-treated wounds, thus fully covering the wounds of one side of the palate before the introduction of PHT-containing gel to the other side, and b) by inserting the custom, palate covering, post-surgical stent immediately after application of the PHT gel. However, there is no statistical test or practical method that can detect this carry-across effect. Additionally, the split mouth study could have also presented difficulties in distinguishing between the two experimental sites for the participants since test and control treatments were performed 
simultaneously. About $40 \%$ of the participants reported no difference in pain between the two sides at post-operative Day 1 and 5 which could have been, in part, a result of the split-mouth simultaneous approach.

Second limitation of this study was small wound size. Routine FGG donor sites are typically twice larger in surface area than the wounds used in the present study. Larger wound size would have potentially allowed us to appreciate differences in complete wound epithelialization as well as patient reported VAS scores.

PHT formulation was matched with carrier in all aspects except the color. This difference in color made identification easier for the clinician (operator applying the treatment) but it also precluded blinding of the investigator performing the clinical assessments, especially up to day 5 . This lack of blinding could have led to a possible bias during evaluations. Although drug delivery was standardized with use of single dose syringes and a thermosensitive viscous carrier was chosen to allow for greater substantivity of the drug, it is was not possible to determine clinically how much drug was actually absorbed. Theoretically, the PHT was delivered at a dose of $18 \mathrm{mg}$ $\mathrm{PHT} / \mathrm{cm}^{2}$. All participants were compliant with the post-operative protocol, including the wearing of post-operative stent, but practically the drug absorbed may still be less due to the dynamic nature of oral cavity.

Future studies that investigate the clinical and patient-centered outcomes of topical phenytoin application to routine FGG donor sites are needed. To eliminate confounding factors, only systemically healthy subjects were recruited in this study. However, based on the results of the present study and previous reports in the literature, 
the effects of topical phenytoin application could prove beneficial in oral wound healing in patients with compromised immunity, such as smokers and diabetics.

Cutaneous wound healing studies have hinted at the anti-microbial effects of PHT $^{18,19,26}$ but the oral cavity presents a very different microbiological environment. Studies are needed to expand upon the understanding of the mechanisms by which topical phenytoin affects the oral wound microbiome and consequently the healing response. This effect should be particularly investigated in smokers as previous studies have reported a microbial shift towards pathogenic bacteria in smokers ${ }^{57}$.

No statistical comparisons were made between males and females in this study because of a significant gender imbalance from the exclusion of female subjects using oral contraceptives. Although gender and race have not been established as risk factors for oral PHT induced gingival overgrowth ${ }^{52}$, it would be interesting to compare effects of topical PHT between genders as previous palatal wound healing studies have reported faster healing outcomes in males compared to females regardless of age ${ }^{44}$.

Overall, to better understand the mechanisms by which PHT affects oral wound healing, and to potentially be able to use such understanding to improve oral wound healing outcomes, further advanced histological and molecular investigations are needed. 


\section{Chapter 6. Conclusions}

The well-established clinical benefits of palatal soft tissue grafts are tempered by associated donor site morbidity and occasional healing delays. In clinical practice, improving patient outcomes is of utmost importance. The greater incidence of donor site pain during early healing of FGG donor sites has made FGG harvest a less attractive soft tissue graft approach despite being easier from a technical standpoint. Several postoperative protocols have been tested to improve donor site patient outcomes but very few are affordable or could be routinely applicable.

Topical phenytoin has been well established in the medical literature as a clinically effective, safe, easy to use, and inexpensive treatment modality for wound healing. Although topical application of phenytoin as a wound healing agent has not been approved by FDA, sufficient evidence exists to justify its off-label prescription upon the clinical discretion of the healthcare professional. ${ }^{58}$

In the present study, topical application of phenytoin resulted in improved objective clinical outcomes of experimental palatal wounds. Although not statistically significant, subjective clinical outcomes were also in favour of phenytoin. No local or systemic side effects to the topical application of the drug were observed during the entire study period. These novel findings on the use of topical phenytoin for postoperative wound management in the oral cavity are encouraging and suggest that larger future 
clinical trials will allow confirmation of the benefits of topical phenytoin in oral wounds, as well as determination of the optimal dose and delivery method. 
Bibliography

1. Chambrone L, Tatakis DN. Periodontal Soft Tissue Root Coverage Procedures: A Systematic Review From the AAP Regeneration Workshop. J Periodontol. 86(2S):S8-51.

2. Del Pizzo M, Modica F, Bethaz N, Priotto P, Romagnoli R. The connective tissue graft: a comparative clinical evaluation of wound healing at the palatal donor site $\mathrm{A}$ preliminary study. J Clin Periodontol. 2002;29(9):848-54.

3. Wessel JR, Tatakis DN. Patient outcomes following subepithelial connective tissue graft and free gingival graft procedures. J Periodontol. 2008 Mar;79(3):425-30.

4. Rossmann JA, Rees TD. A Comparative Evaluation of Hemostatic Agents in the Management of Soft Tissue Graft Donor Site Bleeding. JPER J Periodontol. 1999;70(11):1369-75.

5. Thoma DS, Sancho-Puchades M, Ettlin DA, Hämmerle CHF, Jung RE. Impact of a collagen matrix on early healing, aesthetics and patient morbidity in oral mucosal wounds - a randomized study in humans. JCPE J Clin Periodontol. 2012;39(2):15765.

6. Patel PV, Kumar V, Kumar S, Gd V, Patel A. Therapeutic effect of topical ozonated oil on the epithelial healing of palatal wound sites: a planimetrical and cytological study. J Investig Clin Dent. 2011 Nov;2(4):248-58.

7. Keceli HG, Aylikci BU, Koseoglu S, Dolgun A. Evaluation of palatal donor site haemostasis and wound healing after free gingival graft surgery. J Clin Periodontol J Clin Periodontol. 2015;42(6):582-9.

8. Femminella B, Iaconi MC, Di Tullio M, Romano L, Sinjari B, D'Arcangelo C, et al. Clinical Comparison of Platelet-Rich Fibrin and a Gelatin Sponge in the Management of Palatal Wounds After Epithelialized Free Gingival Graft Harvest: A Randomized Clinical Trial. JPER J Periodontol. 2016;87(2):103-13.

9. Madi M, Kassem A. Topical simvastatin gel as a novel therapeutic modality for palatal donor site wound healing following free gingival graft procedure. Acta Odontol Scand. 2018;76(3). 
10. L. Brunton L, Chabner B, S. Goodman L, Knollmann B. Goodman \& Gilman'S The Pharmacological Basis Of Therapeutics. Vol. 1. 2011. p.

11. Kimball, O. P. \& Horan, T. N. (1939) The use of Dilantin in the treatment of epilepsy. Annals of Internal Medicine 13, 787-793.

12. Hassell TM, Page RC, Narayanan AS, Cooper CG. Diphenylhydantoin (dilantin) gingival hyperplasia: drug-induced abnormality of connective tissue. Proc Natl Acad Sci U S A. 1976;73(8):2909-12.

13. Saito K, Mori S, Iwakura M, Sakamoto S. Immunohistochemical localization of transforming growth factor beta, basic fibroblast growth factor and heparan sulphate glycosaminoglycan in gingival hyperplasia induced by nifedipine and phenytoin. $\mathrm{J}$ Periodontal Res. 1996;31(8):545-55.

14. Kantarci A, Black S, Xydas C, Murawel P, Uchida Y, Yucekal-Tuncer B, et al. Epithelial and connective tissue cell CTGF/CCN2 expression in gingival fibrosis. PATH J Pathol. 2006;210(1):59-66.

15. Shapiro M. Acceleration of gingival wound healing in non-epileptic patients receiving diphenylhydantoin sodium (dilantin, epanutin). Exp Med Surg. 1958;16(1):41-53.

16. Lewis WG, Rhodes RS. Systemic absorption of topical phenytoin sodium. Ann Pharmacother. 1994 Aug;28(7-8):961.

17. Shaw J, Hughes CM, Lagan KM, Bell PM. The clinical effect of topical phenytoin on wound healing: a systematic review. Br J Dermatol. 2007 Nov;157(5):997-1004.

18. el Zayat SG. Preliminary experience with topical phenytoin in wound healing in a war zone. Mil Med. 1989 Apr;154(4):178-80.

19. Modaghegh S, Salehian B, Tavassoli M, Djamshidi A, Rezai AS. Use of phenytoin in healing of war and non-war wounds. A pilot study of 25 cases. Int J Dermatol. 1989 Jun;28(5):347-50.

20. Lodha SC, Lohiya ML, Vyas MC, Bhandari S, Goyal RR, Harsh MK. Role of phenytoin in healing of large abscess cavities. Br J Surg. 1991 Jan;78(1):105-8.

21. Muthukumarasamy MG, Sivakumar G, Manoharan G. Topical phenytoin in diabetic foot ulcers. Diabetes Care. 1991 Oct;14(10):909-11.

22. Menezes J, Rajendran A, Jacob AJ, Vaz M. The use of topical phenytoin as an adjunct to immobilization in the treatment of trophic leprosy ulcers. Southeast Asian J Trop Med Public Health. 1993 Jun;24(2):340-2. 
23. Yadav JK, Singhvi AM, Kumar N, Garg S. Topical phenytoin in the treatment of split-thickness skin autograft donor sites: a comparative study with polyurethane membrane drape and conventional dressing. Burns J Int Soc Burn Inj. 1993 Aug;19(4):306-10.

24. Pendse AK, Sharma A, Sodani A, Hada S. Topical phenytoin in wound healing. Int J Dermatol. 1993 Mar;32(3):214-7.

25. Oluwatosin OM, Olabanji JK, Oluwatosin OA, Tijani LA, Onyechi HU. A comparison of topical honey and phenytoin in the treatment of chronic leg ulcers. Afr J Med Med Sci. 2000 Mar;29(1):31-4.

26. Carneiro PM, Rwanyuma LR, Mkony CA. A comparison of topical Phenytoin with Silverex in the treatment of superficial dermal burn wounds. Cent Afr J Med. 2002 Oct;48(9-10):105-8.

27. Carneiro PMR, Nyawawa ETM. Topical phenytoin versus EUSOL in the treatment of non-malignant chronic leg ulcers. East Afr Med J. 2003 Mar;80(3):124-9.

28. Bhatia A, Prakash S. Topical phenytoin for wound healing. Dermatol Online J. 2004 Jul 15;10(1):5.

29. Younes N, Albsoul A, Badran D, Obedi S. Wound bed preparation with 10-percent phenytoin ointment increases the take of split-thickness skin graft in large diabetic ulcers. Dermatol Online J. 2006 Oct 31;12(6):5.

30. Subbanna PK, Margaret Shanti FX, George J, Tharion G, Neelakantan N, Durai S, et al. Topical phenytoin solution for treating pressure ulcers: a prospective, randomized, double-blind clinical trial. Spinal Cord. 2007 Nov;45(11):739-43.

31. Hokkam E, El-Labban G, Shams M, Rifaat S, El-Mezaien M. The use of topical phenytoin for healing of chronic venous ulcerations. Int J Surg Lond Engl. 2011;9(4):335-8.

32. Fonseka HFS, Ekanayake SMB, Dissanayake M. Two percent topical phenytoin sodium solution in treating pyoderma gangrenosum: a cohort study. Int Wound J. 2010 Dec;7(6):519-23.

33. Pereira CAZ, Alchorne A de O de A. Assessment of the effect of phenytoin on cutaneous healing from excision of melanocytic nevi on the face and on the back. BMC Dermatol. 2010 Aug 24;10:7.

34. Baharvand M, Sarrafi M, Alavi K, Jalali Moghaddam E. Efficacy of topical phenytoin on chemotherapy-induced oral mucositis; a pilot study. Daru J Fac Pharm Tehran Univ Med Sci. 2010;18(1):46-50. 
35. Shaw J, Hughes CM, Lagan KM, Stevenson MR, Irwin CR, Bell PM. The effect of topical phenytoin on healing in diabetic foot ulcers: a randomized controlled trial.

Diabet Med J Br Diabet Assoc. 2011 Oct;28(10):1154-7.

36. Patil V, Patil R, Kariholu PL, Patil LS, Shahapur P. Topical Phenytoin Application in Grade I and II Diabetic Foot Ulcers: A Prospective Study. J Clin Diagn Res JCDR. 2013 Oct;7(10):2238-40.

37. Baharvand M, Mortazavi A, Mortazavi H, Yaseri M. Re-evaluation of the first phenytoin paste healing effects on oral biopsy ulcers. Ann Med Health Sci Res. 2014 Nov;4(6):858-62.

38. Albsoul-Younes A, Younes NA, Badran DH. Topical phenytoin ointment increases autograft acceptance in rats. Saudi Med J. 2006 Jul;27(7):962-6.

39. Hasamnis A, Mohanty B, Muralikrishna null, Patil S. Evaluation of wound healing effect of topical phenytoin on excisional wound in albino rats. J Young Pharm JYP. 2010 Jan;2(1):59-62.

40. Sayar H, Gergerlioglu N, Seringec N, Ozturk P, Bulbuloglu E, Karabay G. Comparison of efficacy of topical phenytoin with hypericin in second-degree burn wound healing: an experimental study in rats. Med Sci Monit Basic Res. 2014 Apr $3 ; 20: 36-46$.

41. Meena K, Mohan AV, Sharath B, Somayaji SN, Bairy KL. Effect of topical phenytoin on burn wound healing in rats. Indian J Exp Biol. 2011 Jan;49(1):56-9.

42. Şimşek G, Ciftci O, Karadag N, Karatas E, Kizilay A. Effects of topical phenytoin on nasal wound healing after mechanical trauma: An experimental study. The Laryngoscope. 2014 Dec;124(12):E449-454.

43. Ai X, Liu H, Lu C, Liang C, Sun Y, Chen S, et al. Phenytoin silver: a new nanocompound for promoting dermal wound healing via comprehensive pharmacological action. Theranostics. 2017 Jan 5;7(2):425-35.

44. Engeland CG, Bosch JA, Cacioppo JT, Marucha PT. Mucosal Wound Healing: The Roles of Age and Sex. Arch Surg. 2006 Dec 1;141(12):1193-7.

45. Silva CO, Ribeiro ÉDP, Sallum AW, Tatakis DN. Free Gingival Grafts: Graft Shrinkage and Donor-Site Healing in Smokers and Non-Smokers. J Periodontol. 81(5):692-701.

46. Er N, Kasaboğlu O, Atabek A, Oktemer K, Akkocaoğlu M. Topical phenytoin treatment in bimaxillary osteomyelitis secondary to infantile osteopetrosis: report of a case. J Oral Maxillofac Surg Off J Am Assoc Oral Maxillofac Surg. 2006 Jul;64(7):1160-4. 
47. Pippi R, Santoro M, Cafolla A. The effectiveness of a new method using an extraalveolar hemostatic agent after dental extractions in older patients on oral anticoagulation treatment: an intrapatient study. Oral Surg Oral Med Oral Pathol Oral Radiol. 2015 Jul;120(1):15-21.

48. Landry RG, Turnbull RS, Howley T. Effectiveness of benzydamine $\mathrm{HCl}$ in the treatment of periodontal post-surgical patients. Res Clin Forums. 1988;10:105-18.

49. Baik H-S, Park J, Lee K-J, Chung C. Local application of periodontal ligament stromal cells promotes soft tissue regeneration. Oral Dis. 2014 Sep;20(6):574-81.

50. Lemo N, Marignac G, Reyes-Gomez E, Lilin T, Crosaz O, Ehrenfest DMD. Cutaneous reepithelialization and wound contraction after skin biopsies in rabbits: a mathematical model for healing and remodelling index. Vet Arh. 2010;16.

51. Chacko LN, Abraham S. Phenytoin-induced gingival enlargement. BMJ Case Rep [Internet]. 2014 May 28 [cited 2019 Jul 9];2014. Available from: https:/www.ncbi.nlm.nih.gov/pmc/articles/PMC4039754/

52. Hassell TM, Hefti AF. Drug-Induced Gingival Overgrowth: Old Problem, New Problem. Crit Rev Oral Biol Med. 1991 Jan 1;2(1):103-37.

53. Hassell TM, Gilbert GH. Phenytoin sensitivity of fibroblasts as the basis for susceptibility to gingival enlargement. Am J Pathol. 1983 Aug;112(2):218-23.

54. Talas G, Brown RA, McGrouther DA. Role of Phenytoin in Wound Healing-A Wound Pharmacology Perspective. :10.

55. G T, T.s.t A, R.a P, M E, R.a B. PHENYTOIN ALTERS DERMAL FIBROBLAST CONTRACTION IN VITRO AND WOUND CONTRACTION IN VIVO. 1996 Jan 1;4(0):A177-A177.

56. Lesaffre E, Philstrom B, Needleman I, Worthington H. The design and analysis of split-mouth studies: what statisticians and clinicians should know. Stat Med. 2009 Dec 10;28(28):3470-82.

57. Kumar PS, Matthews CR, Joshi V, de Jager M, Aspiras M. Tobacco Smoking Affects Bacterial Acquisition and Colonization in Oral Biofilms ${ }^{\nabla}$. Infect Immun. 2011 Nov;79(11):4730-8.

58. Smith RG. Off-label Use of Prescription Medication: A Literature Review. Wounds Compend Clin Res Pract. 2010 Apr;22(4):78-86. 